\author{
Universidade de São Paulo \\ Programa de Pós-Graduação Interunidades em Ensino de \\ Ciências \\ Modalidade Química
}

\title{
Desenvolvimento e aplicação de um método de análise de mapas conceituais com o objetivo de acompanhar mudanças na compreensão de um grupo de alunos sobre o tema Equilíbrio Químico
}

Regina Raquel Gonçalves Cavalcanti 
Regina Raquel Gonçalves Cavalcanti

\section{Desenvolvimento e aplicação de um método de análise de mapas conceituais com o objetivo de acompanhar mudanças na compreensão de um grupo de alunos sobre o tema Equilíbrio Químico}

Orientador: Prof. Dr. Flavio Antonio Maximiano

Dissertação de mestrado apresentada ao Programa de Pós-graduação Interunidades em Ensino de Ciências da Universidade de São Paulo, como parte dos requisitos para a obtenção do título de Mestre em Ensino de Ciências Área de concentração Ensino de Química.

São Paulo

2011 


\title{
FICHA CATALOGRÁFICA
}

Autorizo a reprodução e divulgação total ou parcial deste trabalho, por qualquer meio convencional ou eletrônico, para fins de estudo e pesquisa, desde que citada a fonte.

FICHA CATALOGRÁFICA

Preparada pelo Serviço de Biblioteca e Informação do Instituto de Física da Universidade de São Paulo

\author{
Cavalcanti, Regina Raquel Gonçalves
}

Desenvolvimento e aplicação de um método de análise de mapas conceituais com o objetivo de acompanhar mudanças na compreensão de um grupo de alunos sobre o tema equilíbrio químico - São Paulo, 2011.

Dissertação (Mestrado) - Universidade de São Paulo. Faculdade de Educação, Instituto de Física, Instituto de Química e Instituto de Biociências.

Orientador: Prof. Dr. Flavio Antonio Maximiano

Área de Concentração: Ensino de Química

Unitermos: 1. Mapas Conceituais; 2. Equilíbrio Químico;

3. Ensino e Aprendizagem; 4. Ensino Superior 
2011 


\section{AGRADECIMENTOS}

Este trabalho simboliza e conclui um término de ciclo e começo de outro no caminho da pesquisa e da minha vida.

O maior agradecimento é a Deus por proporcionar discernimento na condução deste trabalho.

São muitas as pessoas a agradecer, primeiramente aos meus pais que me proporcionaram a vida, e as minhas filhas; Larissa no desenvolvimento deste trabalho e a Giovanna por suportar minha ausência em alguns momentos de sua infância.

Agradecimento especial ao meu companheiro até então Alexandre, por me apoiar e estar presente com nossa filha Giovanna durante minha ausência, proporcionando meu êxito na conclusão desta etapa tão importante em minha trajetória acadêmica e profissional.

A minha amiga Ariane, que esteve presente com sua estimável contribuição e seu companheirismo em momentos de dificuldade na elaboração deste trabalho.

A minha irmã, Laura, que me auxiliou na revisão deste trabalho e me deu suporte nos momentos difíceis.

E finalmente aos meus alunos que contribuíram me inspirando durante a trajetória desta pesquisa, e em especial aos meus monitores Gabriele, Alexandre e Andréa. 
CAVALCANTI - GONÇALVES, R.R Desenvolvimento e aplicação de um método de análise de mapas conceituais com o objetivo de acompanhar mudanças na compreensão de um grupo de alunos sobre 0 tema Equilíbrio Químico

Neste trabalho utilizou-se o mapa conceitual como ferramenta para analisar a estrutura conceitual de alunos de um curso de graduação em química de uma universidade pública do estado de São Paulo, sobre o tema equilíbrio químico em dois momentos distintos, o primeiro ao ingressarem na universidade e o segundo após um ano de curso. Os mapas foram analisados utilizando uma adaptação do método de Análise Estrutural de Mapas Conceituais (AEMC adaptada). Teve-se como meta do trabalho: a) Avaliar, através de mapas conceituais elaborados pelos alunos a estrutura conceitual dos mesmos referente ao conceito equilíbrio químico; b) Descrever e analisar a evolução das relações entre os principais conceitos envolvidos no tema feitas por alunos no seu ingresso no curso de graduação e após um ano de curso, quando são submetidos pela primeira vez a um estudo sistemático do tema. Pretendeu-se assim, verificar quais foram às mudanças mais significativas ocorridas em decorrência das disciplinas ministradas neste período e c) Estabelecer uma relação entre estas mudança com o processo de ensino ao qual o aluno foi submetido, ou seja, como a estrutura conceitual dos estudantes a respeito do tema mudou em função do processo de aprendizado a que foram submetidos. Concluiu-se que a ferramenta desenvolvida durante a pesquisa foi muito útil na análise proposta; onde os alunos ingressantes definem o Equilíbrio químico como o estado onde as velocidades das reações se igualam sem relacionar a conceitos da termodinâmica, estes também, demonstraram muitos conhecimentos oriundos de como o conceito é apresentado no ensino médio. Verificou-se também que os estudantes ao serem submetidos à disciplinas relacionadas ao tópico equilíbrio químico modificaram seu entendimento sobre o tema.

Palavras Chaves: Mapas conceituais, Equilíbrio Químico, Ensino e 
Aprendizagem, Ensino Superior

ABSTRACT

CAVALCANTI - GONÇALVES, R.R Development and application of a method of analysis of Concept Maps in order to monitor changes in the understanding of a group of students on the subject of Chemical Equilibrium.

In this work it was used the Concept Map as a tool for analyzing the conceptual structure of students in an undergraduate degree in Chemistry from a public university in the state of São Paulo, on the subject of Chemical Equilibrium at two different times, the first at the moment when entered in the university and second after a year. The maps were analyzed using an adaptation of the method of Structural Analysis of Concept Maps (AEMC adaptada). The objectives of work were: a) Explore and modify a method of analysis of Concept Maps in order to obtain a Concept Map that shows the main conceptual connection of a group of students in order to graphically represent their conceptual structure; b) Evaluate, through Concept Maps prepared by students their conceptual framework for the Chemical Equilibrium concept; c) Describe and analyze the evolution of relations between the main concepts involved on the subject made by students in their admission to the undergraduate course and after one year course, when they are first subjected to a systematic study of the subject. Thus the intention was to verify which were most significant changes occurred as a result of the matter taught in this period and d) Establish a connection between these changes with the teaching process to which the student was submitted, ie, how the conceptual framework of students regarding the subject changed as a function of the learning process they have submitted. It was concluded that the tool developed during the research was very useful in analyzing the proposal, which the new students define the Chemical Equilibrium as state where the velocities of reactions are equal without relating the concepts of thermodynamics, they also showed a lot of knowledge from as the concept is presented in high school. It was also found that students be subjected to the disciplines related to the topic Chemical Equilibrium changed their understanding of the subject, therefore, provide a 
greater number of connections between the different concepts involved on the matter.

Key words: Concept Map, Chemical Equilibrium, Teaching And Learning, University education 


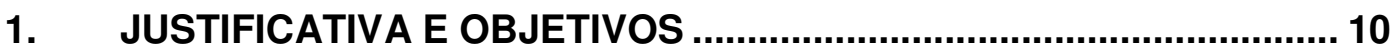

2. FUNDAMENTAÇÃO TEÓRICA ….................................................... 11

2.1 mapas conceituais ................................................................................ 11

2.2 TEMA DA PESQUISA: Equilíbrio químico........................................ 18

3.2 Análise Estrutural de Mapas conceituais (AEMC) …......................... 24

3.3 PROPOSTA METODOLÓGICA: ADAPTAÇÃO DA ANÁlISE ESTRUTURAL DE MAPAS CONCEITUAIS (AEMC ADAPTADA) ...... 27

4. RESULTADOS E DISCUSSÃO …................................................... 38

4.1 Estudo Piloto: ANÁLISE GERAL DOS MAPAS CONCEITUAIS ......... 38

4.2 Estudo Piloto: Obtenção de um mapa conceitual representativo de

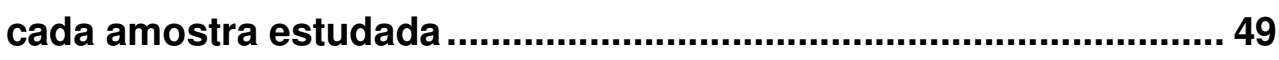

4.3 Estudo das alterações da estrutura conceitual sobre o tema equilíbrio químico em alunos ingressantes no curso de química .. 53

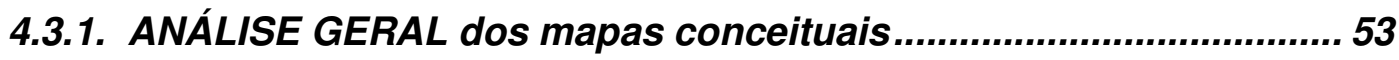

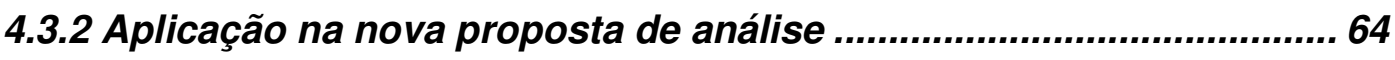

4.3.3 QUANTIFICAÇÃO FREQUÊNCIA DE ASSOCIAÇÃO E do NÚMERO DE

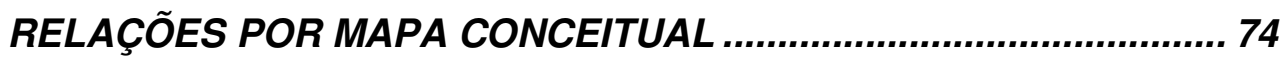

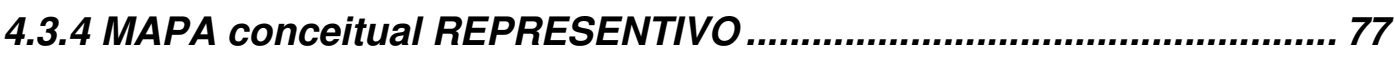

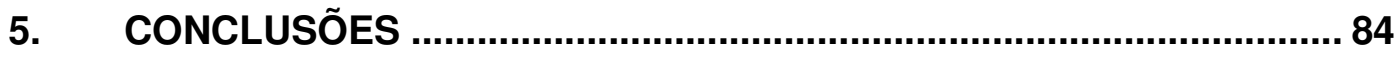

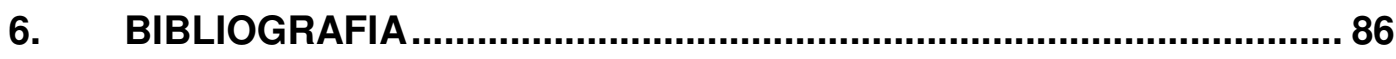

ANEXO 1-Instruções para realização dos mapas conceituais .................... 92 


\section{JUSTIFICATIVA E OBJETIVOS}

A proposta deste trabalho é avaliar qualitativamente a estrutura conceitual dos alunos ingressantes em um curso de graduação em química e após um ano de curso sobre o tema equilíbrio químico, usando como instrumento de coleta de dados mapas conceituais. Escolheu-se trabalhar com essa ferramenta para avaliar uma possível evolução conceitual na estrutura cognitiva dos alunos pois, a mesma permite obter quais são e qual é a natureza das relações entre os principais conceitos envolvidos no tema de maneira a refletir a organização conceitual presente na estrutura cognitiva dos alunos.

O empenho da pesquisadora no tema em questão está pautado em sua observação e atuação em sala de aula, como docente no ensino médio onde o tema é tratado na $3^{\text {a }}$ série, e no ensino superior nos cursos de licenciatura em química e farmácia bioquímica. Durante os anos de experiência lecionando o tema, a percepção de que o tema é de difícil entendimento para os alunos, motivou a realização desta pesquisa. A proposta de observar uma mudança conceitual de um tema de grande importância no contexto da ciência, através de uma metodologia específica, também foi um fator muito relevante para o empenho deste trabalho.

O objetivo do presente trabalho é desenvolver e aplicar uma metodologia de análise de mapas conceituais que permita obter uma visão geral da estrutura conceitual de um certo grupo de alunos sobre um determinado assunto. Para isto foi testada e modificada uma metodologia desenvolvida por González Yoval e colaboradores (2004, 2006, 2008 e 2010), de maneira a se obter um mapa conceitual representativo das principais relações realizadas pelo grupo em estudo. 


\section{FUNDAMENTAÇÃO TEÓRICA}

O tema central abordado neste trabalho é o tópico Equilíbrio Químico e Mapas conceituais, no entanto para que exista uma boa compreensão do assunto, se fez necessário um estudo individual de como se é ensinado e como é compreendido o conceito de equilíbrio químico no ensino médio e ensino superior, bem como o uso de mapas conceituais.

\subsection{MAPAS CONCEITUAIS}

Um mapa conceitual é um diagrama que permite representar graficamente uma organização conceitual. Foi desenvolvido por Joseph Novak e colaboradores com base na teoria da Aprendizagem Significativa de David Ausubel (Ausubel, 1980; Moreira, 2006). O desenvolvimento dos mapas se deu durante um estudo em que analisavam a compreensão conceitual que alunos com doze anos de escolarização apresentavam sobre a natureza particular da matéria (Novak,1991).

Durante o estudo com o intuito de encontrar uma maneira de analisar os dados obtidos, os pesquisadores centraram a atenção para três fatores chave da teoria de Ausubel (1980): 1) a aprendizagem significativa implica a assimilação de novos conceitos e proposições na estrutura cognitiva já existente, resultando em modificações, 2) o conhecimento organiza-se hierarquicamente na estrutura do indivíduo, e na medida em que se aprendem novos conceitos eles são organizados na estrutura hierárquica já existente e 3) o conhecimento adquirido por aprendizagem mecânica não é assimilado na estrutura cognitiva, nem modifica as estruturas de proposições já existentes. Ao reconsiderar o significado dessas ideias, Novak e sua equipe ensaiaram diversos esquemas a fim de representar as estruturas de conhecimentos apresentadas nas entrevistas, até chegarem aos mapas conceituais (Novak,1991, Lourenço, 2008).

Mapa conceituais são formados por conceitos, que podem ser entendidos como regularidades percebidas em eventos ou objetos, 
identificados por um rótulo, geralmente representados por uma palavra ou símbolo, inclusos quase sempre em figuras geométricas como retângulos ou elipses. Os conceitos são unidos por linhas ou setas que apresentam uma frase simplificada ou palavras que evidenciam a relação entre os conceitos, chamadas de frases de ligações (Novak e Gowin, 1988). A essa relação entre dois conceitos por uma frase de ligação dá-se o nome de proposição, que é a unidade semântica básica de um mapa conceitual e evidencia o significado de uma relação conceitual (Novak, 1991). Simplificadamente uma proposição pode ser, por exemplo, "Química é uma ciência “, onde os conceitos são "Química" e "Ciência" e a frase de ligação é "é uma", formando assim uma unidade semântica. Figura 1

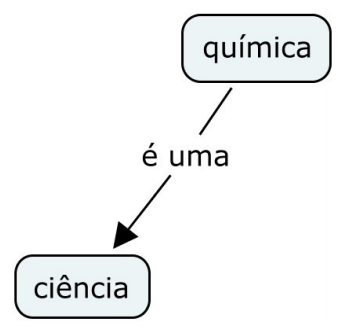

Figura 1: Exemplo de uma proposição

A esta proposição, outras proposições podem ser acrescentadas de maneira a que um mapa conceitual represente uma rede de relações composta por várias proposições diferentes que juntas possam ser uma representação, ou ao menos um reflexo aproximado, da estrutura conceitual de quem o constrói.

As modificações e complementações de um mapa conceitual podem ocorrer em qualquer estágio do aprendizado sobre o assunto, por exemplo, um aluno que tenha elaborado a proposição anterior pode complementar sua definição de química acrescentando a proposição "química estuda a estrutura da matéria", onde os conceitos são "Química" e "Estrutura da matéria" e a frase de ligação "estuda a" (Figura 2). Considerando que as proposições podem se alterar em diferentes etapas da aprendizagem, qualquer conceito pode manter ou alterar uma determinada relação proposicional significativa com os outros conceitos presentes no mapa (Lourenço, 2008, Novak, 1988). Assim, as 
diferenças existentes entre mapas conceituais que foram feitos, ou reelaborados, em diferentes etapas do processo de aprendizado podem ser consideradas como diferenças que denotem mudanças ou reelaboração da estrutura conceitual do aluno que construiu estes mapas.

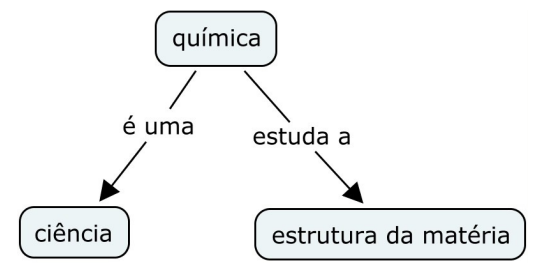

Figura 2: Exemplo de uma possível expansão de um mapa conceitual.

Por ser uma técnica muito versátil, mapas conceituais também têm sido aplicados em um contexto amplo de situações (Cañas et al., 2004) e têm colaborado muito em áreas específicas de pesquisa em educação. Nessa área é possível usar mapas para identificar as ideias prévias dos alunos sobre determinado conceito de maneira a que os mesmos possam externalizar e representar seu conhecimento conceitual a respeito de um determinado tema ou questão. A utilização de mapas conceituais para levantamento de concepções prévias foi, por exemplo, utilizada por Ross et al. (1991), em um trabalho de pesquisa com alunos do ensino superior sob o tema ácidos e bases, por exemplo, onde a discussão de mapeamento de conceitos apontou com sucesso o êxito desta técnica em representar claramente lacunas na compreensão de conceitos que estão inter-relacionados.

Por ser considerado como uma ferramenta de fácil utilização e modificável ao longo do estudo de uma questão específica, mapas conceituais também pode ser usado para auxiliar os alunos a refletirem sobre a estrutura e o processo de produção do conhecimento (Novak, 1988). Segundo Novak (1981), mapas conceituais, servem para esclarecer um determinado domínio de conhecimento, tanto para o aluno quanto para o docente, com uma quantidade abreviada de ideias principais em qualquer tarefa de aprendizagem.

No ensino superior, Freitas Filho (2007) propôs a utilização de mapas conceituais para promover a aprendizagem significativa, de maneira que estes fossem potencialmente facilitadores, com o propósito de motivar o aprendizado 
nos conceitos de química orgânica verificando que esta ferramenta interferiu positivamente no processo de aprendizagem. Os resultados foram obtidos pela análise dos mapas construídos por turmas dos cursos de medicina veterinária, agronomia e zootecnia, em que pode-se verificar e acompanhar o aprendizado do aluno sobre os conceitos da química.

Ainda no ensino superior Pernaa e Maija (2010) utilizaram mapas conceituais para analisar como os alunos, futuros professores de química, utilizam os mapas conceituais como ferramenta de apoio pré-laboratorial. A pesquisa demonstrou que os mapas conceituais podem ser analisados utilizando critérios baseados nas dimensões do conhecimento e das habilidades cognitivas e fornece a útil informação do nível de habilidade metacognitiva dos alunos.

A utilização de mapas conceituais em ensino de química, especificamente em laboratório, também, tem sido utilizada com o propósito de promover o ensino e a aprendizagem significativa do aluno, trabalhos publicados comprovam o êxito desta ferramenta, Markow \& Lonning, (1998) utilizaram mapas para auxiliar os alunos a fazerem conexões conceituais durante os experimentos de química em nível superior, verificando que a aplicação da ferramenta no pré-laboratório e pós-laboratório, auxiliou ao entendimento da química conceitual dos experimentos. Markow \& Lonning trabalharam com universitários ingressantes no curso de química, onde a construção de mapas conceituais foi aplicada objetivando o aumento da aprendizagem dos estudantes, verifica-se que este processo não apresentou diferenças significativas, porém em entrevistas com os estudantes verificaram uma atitude muito positiva para a aplicação da técnica de mapeamento.

Com grande similaridade Kaya (2008) verificou que o mapeamento de conceitos pré e pós laboratório resultou em uma mudança na compreensão conceitual por parte de professores de ciência. Os mapas conceituais foram utilizados como ferramenta de avaliação do curso de laboratório de química, a técnica sugere implicações pedagógicas favoráveis a formação de professores de ciência, e em entrevistas os professores manifestaram opiniões muito favoráveis á técnica de avaliação utilizada. 
Outro uso constante da técnica de mapeamento conceitual é a sua aplicação como uma ferramenta de avaliação do processo de aprendizado (Ruiz-Primo e Shavelson, 1996, McClure, 1999, Ruiz-Moreno et aL, 2007). Nestes casos, a definição método de como se avalia os mapas é de suma importância. Ruiz-Primo e Shavelson (1996), por exemplo, afirmam que os mapas podem ser avaliados por meio de um sistema de contagem em que são atribuídos valores numéricos, o qual pode ser feito de três diferentes formas sendo: contagem dos componentes dos mapas (proposição, níveis de hierarquia e exemplos), comparando o mapa conceitual do estudante com um mapa conceitual padrão ou utilizando uma combinação de ambas as estratégias. McClure (1999) ensaiou diferentes métodos e critérios de pontuação para análise de mapas conceituais recomenda que os professores devem utilizar a pontuação numérica obtida pelos mapas como um levantamento inicial, o qual pode indicar as áreas onde os conhecimentos estão mais compreendidos ou não. Todos estes estudos têm fornecido informações importantes sobre as técnicas de avaliar um mapa conceitual, porém, entende-se que apenas a análise estatística dos mapas não representa a estrutura cognitiva dos aprendizes.

Ruiz-Moreno (2007) em seu trabalho com alunos de pós-graduação de uma disciplina sobre educação em saúde, utilizou mapas conceituais como técnica de avaliação, em que usou as seguintes categorias para análise dos mapas: a) quantidade, qualidade de conceitos e nível de hierarquia; b) linhas de cruzamento entre conceitos; c) proposições com significado lógico (ponto de vista semântico); d) estrutura do mapa (sequencial, relações cruzadas, interrelações não hierárquica). Para 0 autor a análise quantitativa deve ser acompanhada de uma análise qualitativa que, no caso, foi realizada através análise da estrutura dos mapas; os critérios adotados mostraram uma potencialidade motivadora pela análise qualitativa e quantitativa. Por parte dos docentes, a aplicação da técnica de mapeamento conceitual auxiliou na ênfase e nas escolhas futuras dos tópicos teóricos conceituais a serem aplicados, tornando-se assim uma ferramenta útil ao processo de ensino.

Ainda com a proposta de analisar mapas conceituais González Yoval e colaboradores $(2004,2006,2010)$ apresentam em seus trabalhos uma 
metodologia de análise de mapas conceituais pautada na análise bidimensional e utilização de ferramentas estatísticas. Seus trabalhos foram realizados com alunos de ensino intermediário ao universitário e ingressantes do nível universitário em uma disciplina de biologia. Nestes trabalhos análise bidimensional permitiu categorizar os conceitos como: a) dominantes, b) ocasionais, c) constantes e d) raros; os quais podem ser de grande valia para o docente visto que a partir destas relações poderá conduzir sua organização de tópicos e conteúdos a serem ministrados.

A metodologia utilizada por González Yoval e colaboradores será melhor detalhada no desenvolvimento deste trabalho, visto que trata-se do fundamento metodológico escolhido para a pesquisa em questão.

Antes de prosseguir é importante ressaltar um último aspecto com relação à construção de mapas conceituais. A partir de uma mesma lista de conceitos é possível representar diferentes mapas conceituais de acordo com a perspectiva, os objetivos e a estrutura conceitual de quem constrói o mapa e do contexto em que o mesmo é construído. Um exemplo disto é apresentado por Novak (1988) e aqui é representado nas( figuras 3 e 4). Pode-se observar que os dois mapas apresentem aspectos estruturais diferentes principalmente com relação à hierarquia dos conceitos envolvidos, uma vez que no mapa apresentado na (figura 3) o conceito mais geral, de onde se inicia a construção das relações e proposições, é o de molécula, enquanto que 0 na figura 40 conceito mais geral é o de seres vivos. No entanto, uma análise mais minuciosa mostra que as relações $\mathrm{e}$ as proposições principais são coincidentes, de maneira que podemos considerar que os dois mapas conceituais sejam representações de uma mesma ideia, ou seja, representam uma mesma estrutura conceitual.

Diante disto, o presente trabalho tem como foco observar as relações e proposições encontradas em mapas conceituais, e não a sua estrutura geral. 


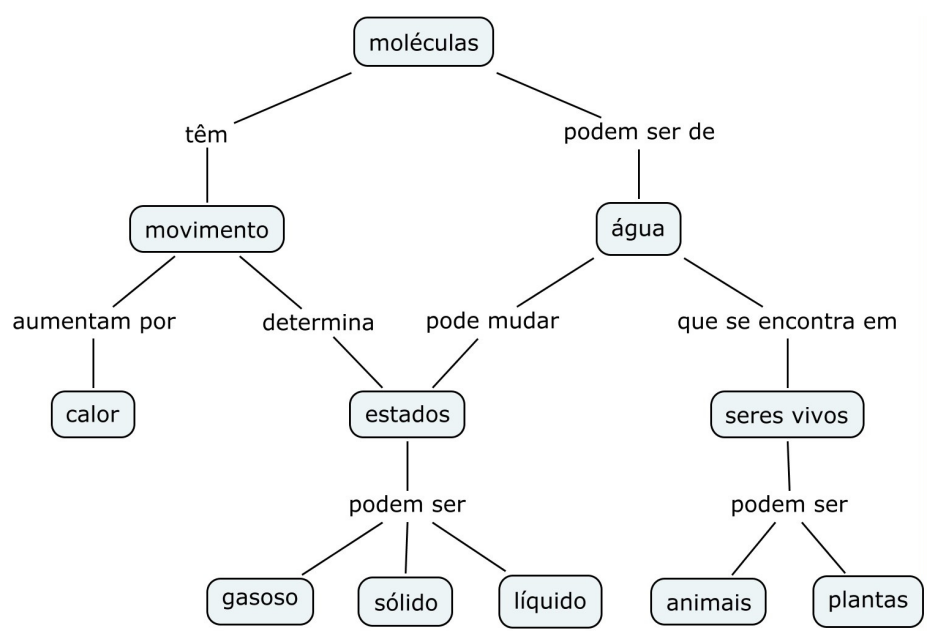

Figura 3: Mapa conceitual partindo do conceito de moléculas. Extraído de Novak 1988.

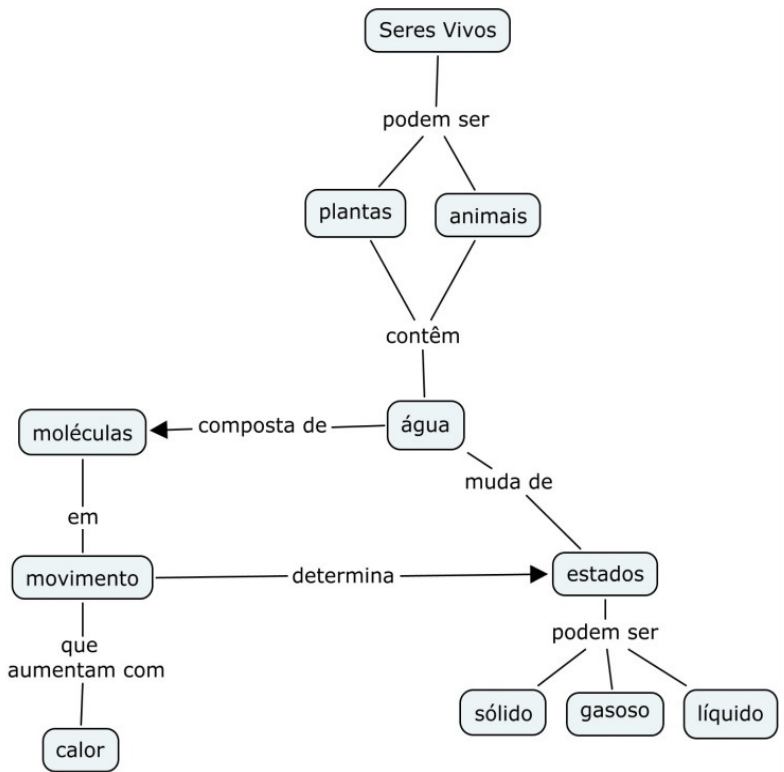

Figura 4: Mapa conceitual partindo do conceito de seres vivos. Extraído de Novak 1988 


\subsection{TEMA DA PESQUISA: EQUILÍBRIO QUÍMICO}

A química é considerada uma ciência difícil de ser estudada e compreendida pelos alunos que, ao iniciarem os estudos desta ciência, costumam trazer consigo concepções prévias que muitas vezes atuam como verdadeiros obstáculos ao aprendizado conceitual desejado (Johnstone, 2007). Neste contexto, o tema equilíbrio químico é considerado como um dos tópicos mais complexos e exigentes para o aprendizado do aluno do ensino médio ou de cursos introdutórios de química no ensino superior (Wilson, 1998; Stewart et al, 1982; Mendonça, 2005).

O tema equilíbrio químico pode ser visto como uma síntese de conceitos e princípios químicos mais gerais (Camacho e Good, 1989) e por isso, demanda o domínio de um grande número de conceitos subordinados (QuilezPardo e Solaz-Portoles, 1995) como reação química, reversibilidade das reações, velocidade de reações entre outros. Trata-se também de um dos tópicos mais relevantes para o entendimento de outros tópicos da química como o comportamento ácido-base, reações de óxido-redução e solubilidade, sendo que a falta de conhecimento e de domínio de seus princípios, ou a falta de habilidade em transferir estes princípios a outros domínios, é fonte de dificuldades que os alunos encontram no estudo desses tópicos acima citados (Quilez-Pardo e Sanjosé-Lopes, 1995). O entendimento da natureza dinâmica do equilíbrio requer, por exemplo, uma clara compreensão de como as reações químicas se passam ao nível molecular (Maskill e Cachapuz, 1989), como ocorre uma reação química e o que é o estado de equilíbrio as relações com a cinética de uma reação química e estequiometria da mesma.

De forma geral, no Brasil, o tema equilíbrio químico costuma ser abordado no final do segundo ano ou no início do terceiro ano do ensino médio, após os alunos terem estudado o tópico cinética química. Neste nível de ensino, a abordagem deste tópico no ensino médio é, via de regra, feita de forma a não abranger o ponto de vista termodinâmico, o que acarreta grande prejuízo aos alunos ao se depararem com o tema no ensino superior, onde precisam de uma clara distinção e definição de conceitos cinéticos e termodinâmicos (Sabadini e Bianchi, 2007). 
Um aspecto importante a se destacar é que muitas vezes, ao iniciar os estudos sobre o tema, o que os estudantes pensam a respeito do equilíbrio químico está relacionado ao equilíbrio físico dos corpos, como por exemplo à ideia do "manter-se em equilíbrio", ao equilibrar os pesos em uma balança ou ao conseguir andar de bicicleta. Experiências estas que se manifestam quando o assunto é introduzido, geralmente, através de uma pergunta motivadora. Esta ideia de equilíbrio estático e sua direta transposição para o contexto do equilíbrio químico indica a não compreensão do assunto no nível atômicomolecular.

Segundo Tsarpalis et al (1998), os problemas que envolvem equilíbrio químico estão entre os mais importantes, complexos e difíceis encontrados nos curso de Química Geral. Sendo assim, não é surpresa que muitos pesquisadores tenham se dedicado a este tema em uma vasta perspectiva que vai desde levantar as dificuldades e concepções alternativas apresentadas pelos alunos (Furio-Mas e Ortiz, 1983 e Thomas e Schwenz, 1998), até propor novas metodologias de ensino, como por exemplo, através de resolução de problemas (Camacho e Good, 1989), utilização de jogos (Wilson, 1998) ou sistematização de processos industriais (Uehara 2008).

As dificuldades na aprendizagem do equilíbrio químico estão relacionadas com a sua natureza abstrata (Johnstone, 1977), presente em conceitos como natureza dinâmica do equilíbrio químico, princípio de Le Chatelier, velocidade de reação, entropia, entalpia e estudos da termodinâmica relacionadas a equilíbrio químico. Uma importante revisão das concepções a respeito de equilíbrio químico foi realizada em Raviolo e Aznar (2003). Dos 28 trabalhos analisados onze deles envolvem estudos com alunos do ensino superior. Desses, nove investigam as concepções de alunos do primeiro ano do curso universitário, apenas um levanta as concepções de alunos que cursam uma disciplina de físico-química. O trabalho encontrou uma grande quantidade de concepções alternativas e dificuldades que foram classificadas em oito categorias definidas como: a) Conceitos prévios necessários para 0 estudo do equilíbrio químico; b) Características de um sistema em equilíbrio químico; c) Linguagem, simbolismo empregado e constante de equilíbrio; d) 
Efeito de mudança de variáveis sobre o sistema em equilíbrio; e) Velocidade de reação; f) Catalisadores; g) Energia e h) Equilíbrios heterogêneos.

Mesmo alunos de cursos introdutórios de química em nível superior exibem uma grande quantidade de concepções alternativas que têm um importante papel no aprendizado desta ciência, produzindo explicações inadequadas a questões importantes. Podemos inferir que umas das dificuldades verificadas por parte dos estudantes é que durante o ensino médio o tópico equilíbrio químico é pautado na resolução de problemas algorítmicos mais do que no entendimento conceitual.

Segundo Canzian e Maximiano (2010) vários trabalhos têm apontado dificuldades e erros conceituais relacionados ao tema equilíbrio químico, tais como, o problema de analogias utilizadas por professores e por livros didáticos, Canzian focou seu trabalho em descrever especificamente, como o Princípio de Le Chatelier é formulado e discutido em livros didáticos brasileiros para o Ensino Médio; concluindo que estes podem gerar erros conceituais significativos.

Importante salientar que os livros didáticos servem de base para uso metodológico educacional, Canzian e Maximiano (2010) ainda, verificaram em seu trabalho que, os livros didáticos, em geral, apresentam os enunciados do Princípio de Le Chatelier de forma geral e concisa, utilizando termos de caráter vago e simplificado, os quais podem levar ao aluno a ideia errada de que a evolução de um sistema em equilíbrio químico ou até mesmo o estado de equilíbrio se resume a uma generalização memorística.

De acordo com Uehara (2008) existe uma necessidade de hierarquizar e organizar as dificuldades conceituais sobre o tópico equilíbrio químico, assim o professor poderá expor os conteúdos de maneira estratégica, tornando-se um facilitador da aprendizagem, tendo em vista o formato com que ele irá organizar os conteúdos. Podemos entender que a maneira como os estudantes organizam seus conhecimentos a partir de suas próprias conclusões sobre 0 conteúdo estão relacionadas com as dificuldades de aprendizagem. 


\section{ASPECTOS METODOLÓGICOS}

\subsection{A COLETA DOS DADOS}

Tendo em vista o objetivo de verificar, através da construção de mapas conceituais, as mudanças na estrutura conceitual de alunos do primeiro ano do curso de graduação em química do período noturno de uma universidade pública do estado de São Paulo, sobre o tema equilíbrio químico, optou-se por realizar previamente um estudo piloto. Os objetivos deste estudo piloto eram o de melhor definir tanto a forma de coleta de dados (construção dos mapas conceituais pelos alunos) como a forma de análise dos mesmos, de maneira a explorar os limites e possibilidades da técnica AEMC(Análise Estrutural de Mapas Conceituais) proposta por González Yoval e colaboradores (2004).

Assim, em 2007, fez-se um teste prévio com 67 alunos do terceiro ano do curso graduação em química, sendo 31 alunos do curso do período integral e 36 do curso do período noturno, ambos matriculados na disciplina Química Integrada III.

Antes da elaboração dos mapas, os alunos tiveram aula inicial de cinqüenta minutos sobre mapa conceituais, em que foi feita uma apresentação dessa ferramenta, baseada nas sugestões apresentadas em Ruiz-Primo et al (2001). Tal apresentação envolveu uma explicação a respeito do que são mapas conceituais, para que servem, como se forma uma proposição, exemplos de mapas conceituais, quais as diferenças entre mapas conceituais e outras representações gráficas, quais as estruturas mais comuns de mapas conceituais, como representar a hierarquia de conceitos e quais os passos necessários para elaborar um mapa conceitual. Ao final da aula os alunos construíram um mapa conceitual sobre o conceito elemento químico envolvendo nove conceitos, sendo: átomo, elemento químico, homogêneo, heterogêneo, material, mistura, substância composta, substância

pura, substância simples. Durante a elaboração desses mapas a pesquisadora percorreu as carteiras sanando possíveis dúvidas quanto a construção dos mesmos. 
$\mathrm{Na}$ aula seguinte (após uma semana), os alunos receberam uma folha com instruções (ANEXO 1) de como elaborar um mapa conceitual e uma lista em ordem alfabética, com 37 conceitos relacionados ao tema equilíbrio químico. A lista de conceitos (tabela 1) foi elaborada e definida a partir da leitura de livros-didáticos de química geral (Kotz e Treichel, 2002), química analítica (Skoog, et al., 2005) e físico-química (Ball, 2005). O critério da escolha dos conceitos se deu a partir dos que apresentavam maior freqüência nos textos dos respectivos livros. Os alunos foram instruídos que não precisavam utilizar todos os conceitos e ainda poderiam acrescentar outros não elencados, desde que fossem pertinentes ao tema. $O$ tempo utilizado para a elaboração dos mapas foi de até duas horas, e vários alunos refizeram seus mapas nesse período.

Tabela 1 - Conceitos utilizados na primeira etapa de elaboração dos mapas conceituais, realizada no segundo semestre de 2007.

\begin{tabular}{ccc}
\hline ácido-base & exotérmico & reação favorável \\
catalisador & extensão de reação & inversa \\
concentração(ões) & íon comum & reages \\
constante de equilíbrio(K) & macroscópico & rendimento da reação \\
deslocamento de & microscópico & reversibilidade \\
equilíbrio & potencial químico & solubilidade \\
dinâmico & pressão & temperatura \\
endotérmico & princípio de Le Chatelier & variação de energia livre $(\Delta \mathrm{G})$ \\
exotérmico & variação de energia livre \\
equação da constante de & produto de solubilidade & padrão $\left(\Delta \mathrm{G}^{\circ}\right)$ \\
equilíbrio & produtos & variação de entalpia $(\Delta \mathrm{H})$ \\
equação química & velocidade de reações \\
equilíbrio químico & quociente de reação $(\mathrm{Q})$ & volume \\
estado de equilíbrio & reação direta & \\
estado estacionário & &
\end{tabular}

Após a análise detalhada dos mapas (descrita a seguir) uma nova lista (tabela 2) com uma quantidade menor de conceitos foi elaborada com base nos conceitos mais utilizados pelos alunos para a elaboração do mapa sobre equilíbrio químico. No entanto, foram preservados conceitos considerados importantes, ou os que se desejava ver que tipo de relações os alunos seriam capazes construir. É o caso dos conceitos relacionados à Termodinâmica $(\Delta \mathrm{G}$ Variação de Energia Livre de Gibbs, $\Delta \mathrm{G}^{\circ}$-Variação de Energia Livre de Gibbs 
Padrão, e potencial químico). Além de diminuir o tempo e conseqüentemente um possível cansaço na execução da tarefa, um número menor de conceitos permitiu focar mais as relações entre os conceitos que mais foram utilizados na segunda etapa, a qual será explicitada na sequência.

Tabela 2 - Lista com os 28 conceitos utilizados na segunda etapa de elaboração dos mapas conceituais.

\begin{tabular}{ccc}
\hline concentração & macroscópico & reação inversa \\
constante de equilíbrio $(\mathrm{K})$ & microscópico & reação química \\
deslocamento de equilíbrio & perturbação & reagentes \\
dinâmico & potencial químico & reversível \\
direção da reação & pressão & temperatura \\
endotérmico & produtos & variação de energia livre $(\Delta \mathrm{G})$ \\
equilíbrio químico & princípio de Le Chatelier & variação de energia livre \\
& & padrão $\left(\Delta \mathrm{G}^{\mathrm{o}}\right)$ \\
exotérmico & quociente de reação $(\mathrm{Q})$ & velocidade de reações \\
extensão de reação & reação direta & volume \\
lei de ação das massas & & \\
\hline
\end{tabular}

Uma vez testada e modificada a metodologia de coleta de dados, essa foi aplicada, em maio de 2008, a 49 alunos ingressantes do curso noturno de bacharelado em química, matriculados na disciplina "Introdução às Transformações Químicas", ressalta-se que o tema equilíbrio químico não havia sido abordado na disciplina no momento desta coleta de dados, portanto, antes de estudarem o tópico equilíbrio químico. Em novembro do mesmo ano, novos dados foram coletados com a mesma metodologia, a fim de analisar a evolução conceitual ou não desses alunos sobre o tema equilíbrio químico, visto que estes já haviam cursado as disciplinas de Introdução às Transformações Químicas, Química Inorgânica e Estrutura da matéria. Dos 49 alunos ingressantes que construíram o mapa em maio, apenas 17 construíram o segundo mapa em novembro na disciplina de Química Inorgânica. Outros 12 alunos participaram apenas dessa última coleta de dados. Neste trabalho apenas os 17 alunos que participaram dos dois momentos de coleta de dados serão considerados, assim com o propósito da verificação dos objetivos desta pesquisa. 


\subsection{ANÁLISE ESTRUTURAL DE MAPAS CONCEITUAIS (AEMC)}

A metodologia AEMC (Análise Estrutural de Mapas Conceituais) proposta por González Yoval e colaboradores (2006), consiste em uma combinação de técnicas:

a) Construção de mapas conceituais pré preenchido "fill-in-map"(FM) (Ruiz-Primo 2001,2004, Yin 2005),

b) Análise Estrutural da Educação (EEA) (Solano 1989),

c) Utilização do Teste e Associação Bidimensional Olmsted-Tukey (Sokal \& Rohlf 1985, Garcia de León 1988),

d) Comparação de mapas conceituais construídos pelos alunos ao mapa conceitual do especialista.

Com o intuito de analisar e verificar o aprendizado e compreensão da ciência e tecnologia, González Yoval e colaboradores desenvolveram a técnica (AEMC) para analisar e validar mapas conceituais, como ferramenta para promover a aprendizagem.

A técnica chamada pelos autores de AEMC consiste em transformar cada mapa construído pelos alunos em uma matriz de associação onde cada ligação existente entre dois conceitos distintos (proposição) é marcado com o número 1 a partir da linha do conceito de onde se inicia a leitura da proposição (ou de onde parte a seta que indica a ligação entre os conceitos). Assim, por exemplo, para o mapa conceitual representado na figura 5, a proposição "equilíbrio químico $\rightarrow$ pode ser afetado segundo $\circ \rightarrow$ Princípio de Le Chatelier" é marcada na matriz de associação na intersecção entre a linha correspondente ao conceito equilíbrio químico e a coluna correspondente ao conceito Princípio de Le Chatelier".

As matrizes, correspondentes a cada um dos mapas conceituais, são em seguida somadas dando origem a uma matriz de associação final que apresenta o total de relações existentes entre cada possível par de conceitos, ou seja representa a soma de todas as relações feitas em todos os mapas conceituais analisados. 
Dois importantes parâmetros são então obtido a partir da matriz de associação final:
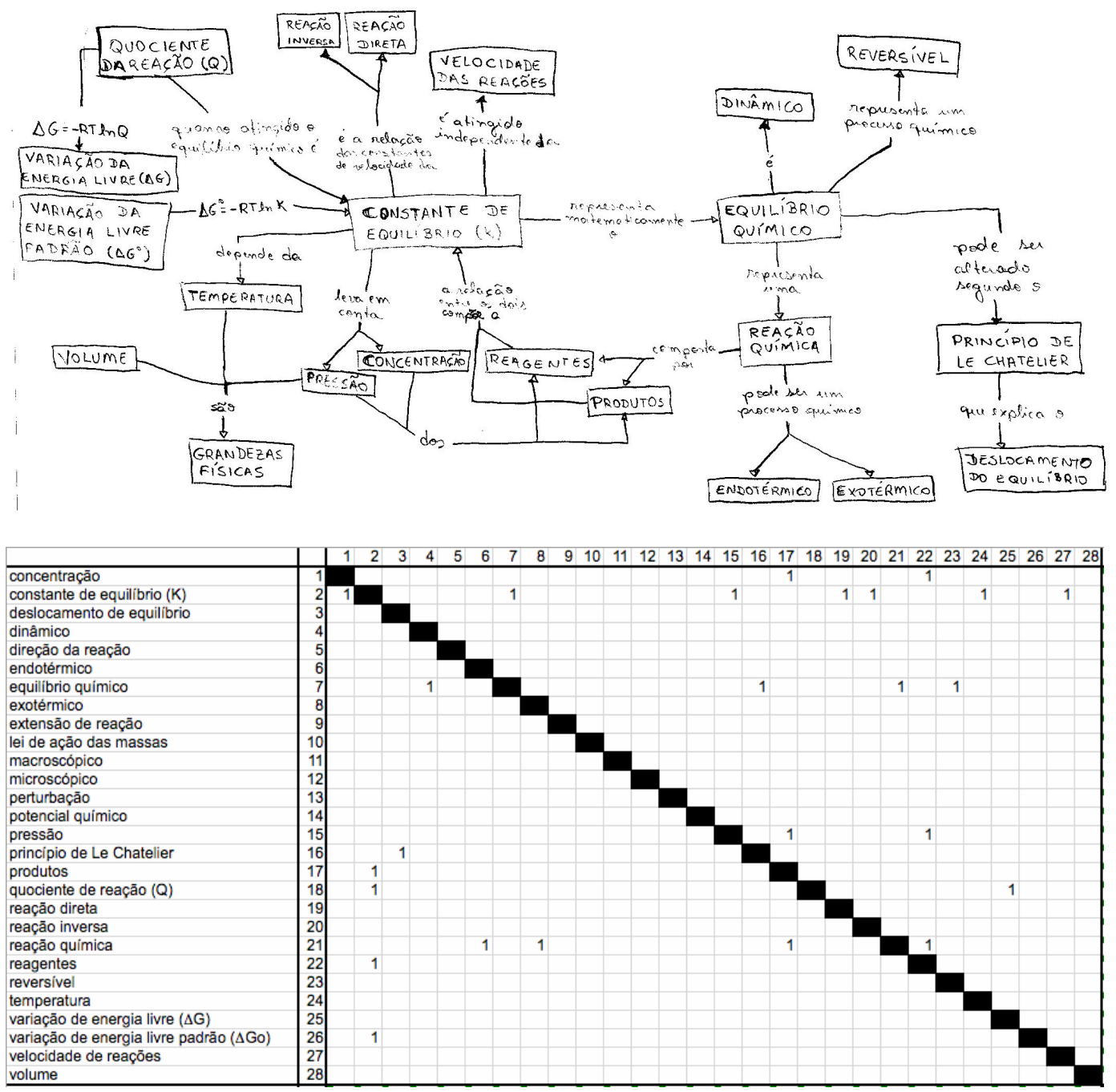

Figura 5 - Mapa conceitual produzido por um aluno e matriz de associação de conceitos correspondente ao mesmo.

- $\quad$ O total de relações $(\mathrm{R})$ feitas para cada conceito, através da soma de todos os valores presentes em cada uma das linhas.

- A contagem do número de conceitos distintos que foram relacionados com cada um dos conceitos, definida como frequência de relações $(F)$, que pode ser expresso percentualmente $(\% \mathrm{~F})$ dividindo este valor pelo número total 
de diferentes ligações que posem ser feitas para cada conceitos, ou seja, pelo valor de $\mathrm{n}-1$, onde $\mathrm{n}$ é o número total de conceitos fornecidos aos alunos.

A esses dois parâmetros (Relações e Frequência) se aplica a prova de Associação de Olmsted - Tukey também conhecida por Análise Bidimensional, o que consiste em construir o gráfico Número de Relações (R) vs. Freqüência de Associação (\%F). Ao se traçar linhas que passem pelos valores das medianas dos dois parâmetros (Figura 6), o gráfico é dividido em quatro quadrantes; que permitem classificar os conceitos em: dominantes (maior frequência de associação - \%F e maior número de relações - $R$ ) ocasionais (menor \% F e maior R); constantes (maior \%F e menor R) e; raros (menor \%F e menor R).

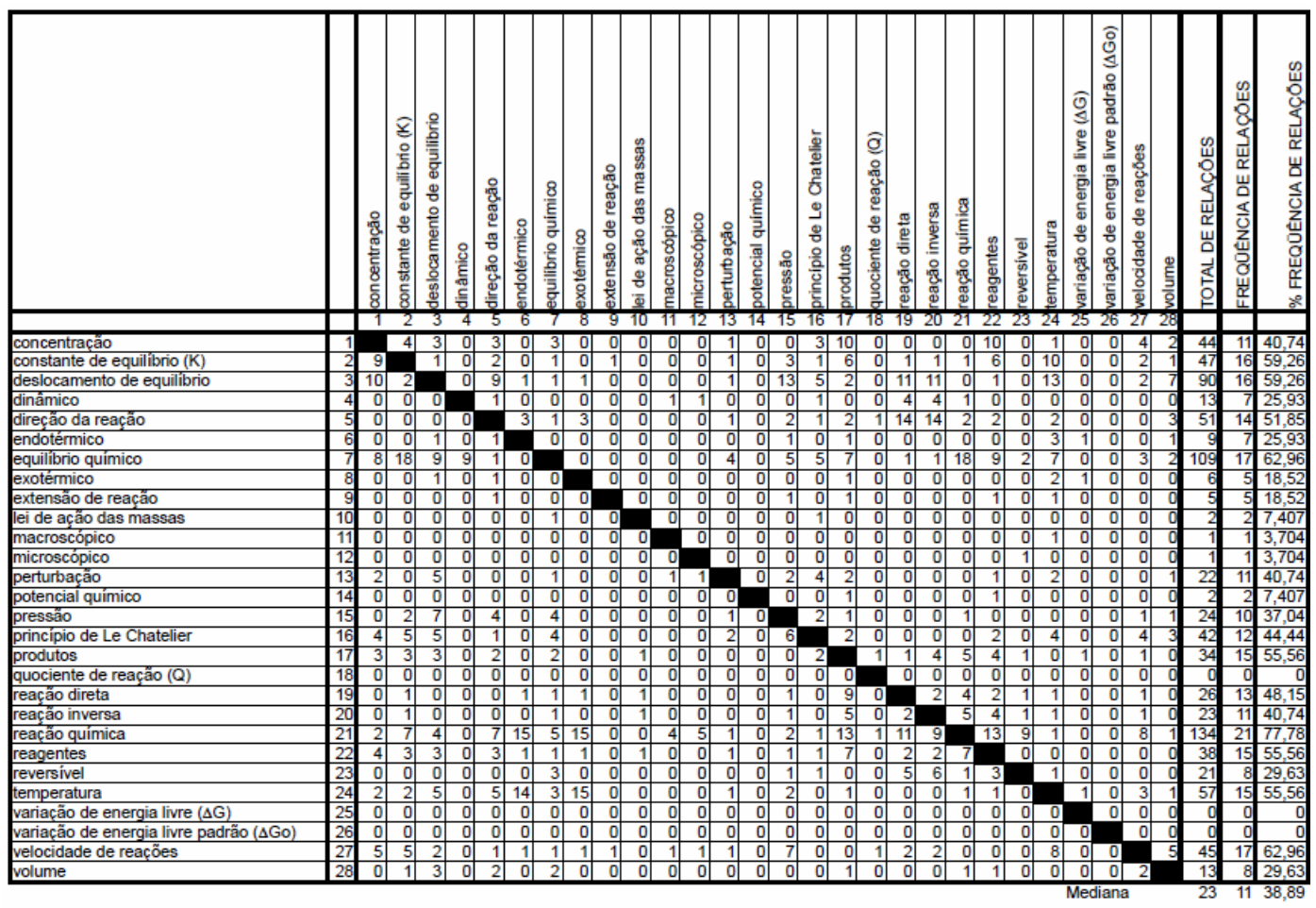

Figura 6- Matriz de associação final obtida através da soma de todos os mapas conceituais construídos por um determinado grupo de alunos. A matriz apresenta, para cada conceitos o total de relações a frequência de associação para cada um dos conceitos. A partir da posição destes valores com relação às suas medianas, os conceitos são classificados em: dominantes, raros, constantes ou ocasionais. 


\subsection{PROPOSTA METODOLÓGICA: ADAPTAÇÃO DA ANÁLISE ESTRUTURAL DE MAPAS CONCEITUAIS (AEMC ADAPTADA)}

Segundo a metodologia original (González Yoval et. al., 2006), para uma determinada proposição existente no mapa conceitual, se pode assinalar, na matriz, a relação entre os conceitos e também efetuar a soma das relações, seguindo tanto as linhas quanto as colunas da matriz. No entanto, ao aplicar tal metodologia, percebe-se que o efeito deste procedimento é de que os conceitos terminais do mapa conceitual, bem como sua relação não seriam marcados. Por exemplo, se em um mapa (figura 7) existe a proposição $\Delta G \rightarrow$ indica a $\rightarrow$ reação favorável, de maneira que este último conceito não se ligue em nenhum outro (conceito terminal), seguindo a linha da matriz (figura 8) somente $\Delta \mathrm{G}$ terá seus valores de $\mathrm{R}$ e $\mathrm{F}$ computados.

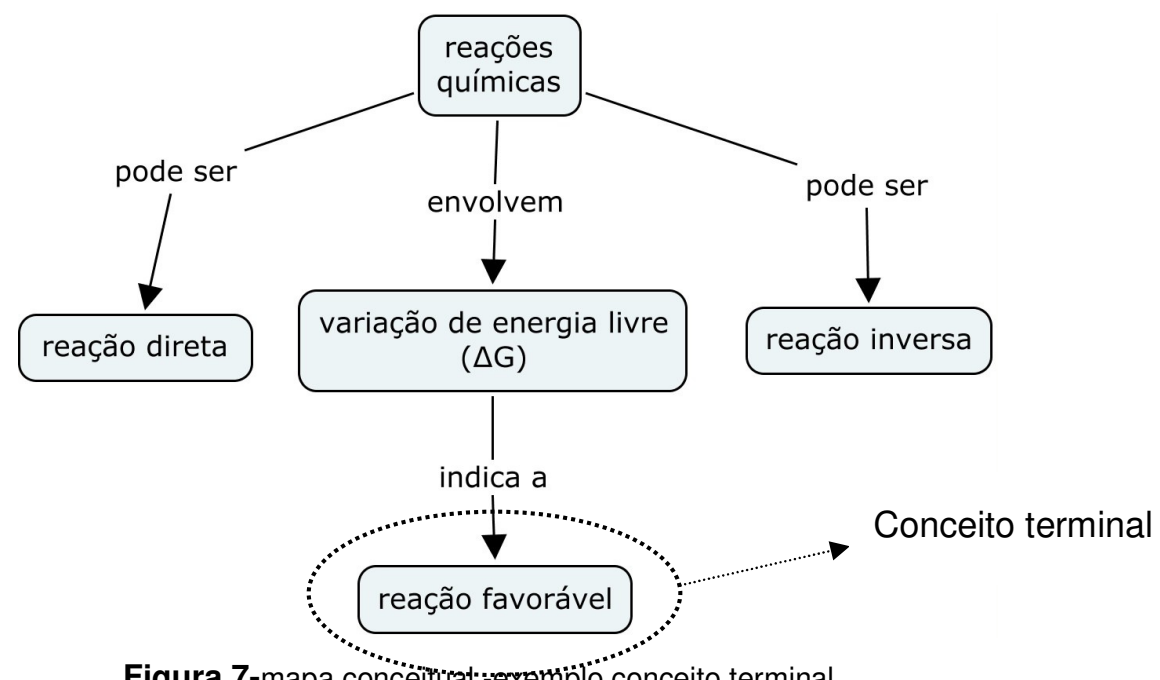

Figura 7-mapa conceiturat-"exemplö conceito terminal 


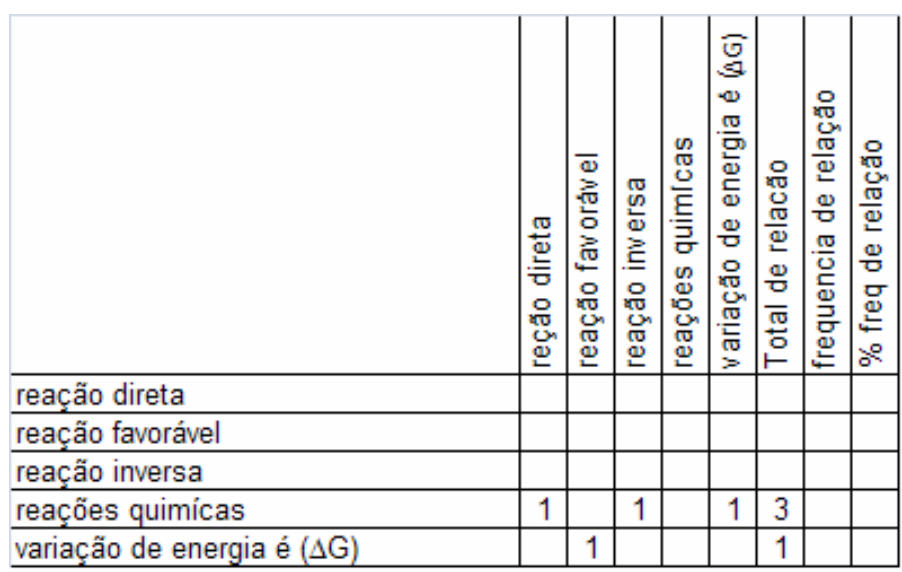

Figura 8- matriz de associações -exemplo

Para evitar este tipo de problema e computar os conceitos terminais, a Análise Estrutural de Mapas Conceituais (AEMC), González Yoval (2006) foi adaptada para o presente trabalho e consiste nos seguintes passos:

\section{- Construção de matrizes}

1) Cada mapa conceitual, construído pelo aluno, é transformado em uma matriz de associação, em que, para cada par de conceitos com uma relação, uma proposição, existente é atribuído o valor 1. Na Figura 9 é apresentada a matriz correspondente ao mapa conceitual da Figura 10, construído por um aluno do terceiro ano durante o estudo piloto. No entanto, percebemos que ao efetuar esse procedimento os conceitos terminais do mapa não seriam devidamente marcados, conforme já descrito e exemplificado. Assim, as matrizes foram divididas pela diagonal nula e cada par de conceitos foi marcado na diagonal inferior e superior, marcando a relação entre determinados conceitos A e B tanto pela linha quanto pela coluna. Isto produziu uma matriz simétrica (Figura 9 e Figura 11).

2) Para cada amostra de mapa, é efetuada uma soma de todas as matrizes obtendo-se assim uma matriz soma final que mostra o número de relações total em cada conceito conforme apresentado na Figura 11.

3) Da mesma forma que na proposta original, a soma das linhas permite obter o valor de R para cada conceito. A contagem, seguindo a linha da matriz, do número total de conceitos que um determinado conceito $\mathrm{X}$ aparece 
relacionado indica o valor de $\mathrm{F}$. Esse valor pode ser dividido pelo número total de relações que se pode estabelecer com o respectivo conceito $X(n-1$, onde $n$ é o número total de conceitos) e expresso em termos porcentuais (\%F). Outra modificação foi normalizar o número total de relações $(R)$ dividindo-o pelo número total de mapas de cada grupo obtendo a razão total d relações/mapa (R/M). Esse parâmetro representa o número médio de relações do conceito em cada amostra de alunos estudada, o que permite uma melhor comparação entre os mesmos (Figura 12).

- Construção de gráfico \% Frequência de associação vs. Relações/Mapa

4) A aplicação da Prova de Associação de Olmstead-Tukey (González Yoval, 2004) consiste em construir o gráfico que relaciona o total de relações $(R / M)$ e a freqüência de associação (R/M vs. F). O gráfico obtido é dividido em quadrantes determinados pelas medianas de Relações e Frequência (Figura 12).

Á partir dos resultados obtidos pela posição gráfica dos conceitos, definise:

- Conceitos dominantes- aqueles que possuem alto número de relações e alto número de freqüência, presentes nos mapas analisados.

- Conceitos constantes- aqueles que possuem baixo número de relações e alto número de freqüência, presentes nos mapas.

- Conceitos ocasionais- aqueles que possuem alto número de relações e baixo número de freqüência, presentes nos mapas.

- Conceitos raros- aqueles que possuem baixo número de relações e baixo número de freqüência, presentes nos mapas.

Assim, pela posição de cada conceito em um quadrante, pode-se determinar quais dos conceitos são dominantes (alto $R$ e alto $F$ ), constantes (baixo $R$ e alto $F$ ), ocasionais (alto $R$ e baixo $F$ ) e raros (baixo $R$ e baixo $F$ ). Figura 12 


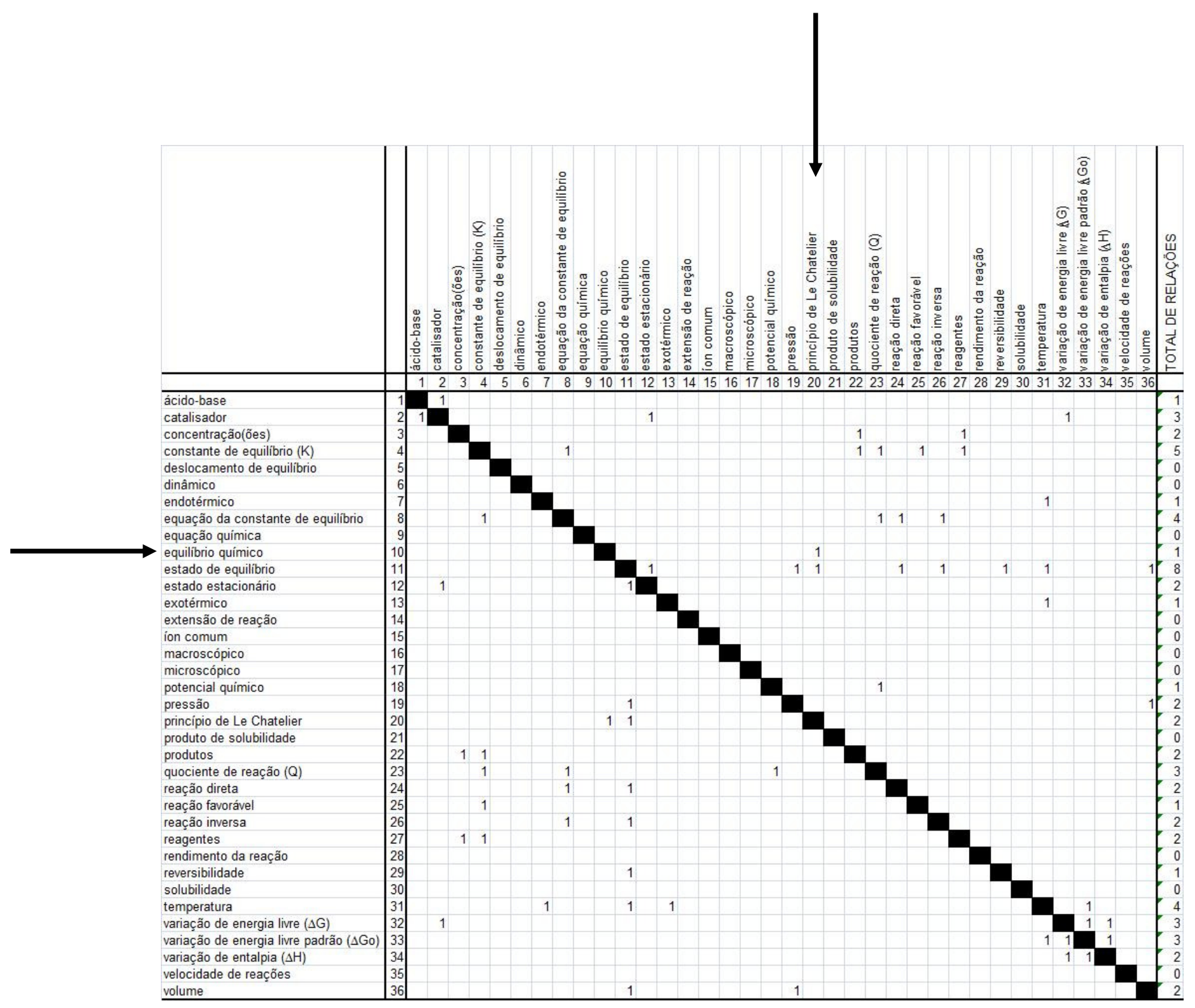

Figura 9-Matriz obtida a partir de um mapa conceitual elaborado por aluno_11 do 30 ano do curso integral. 


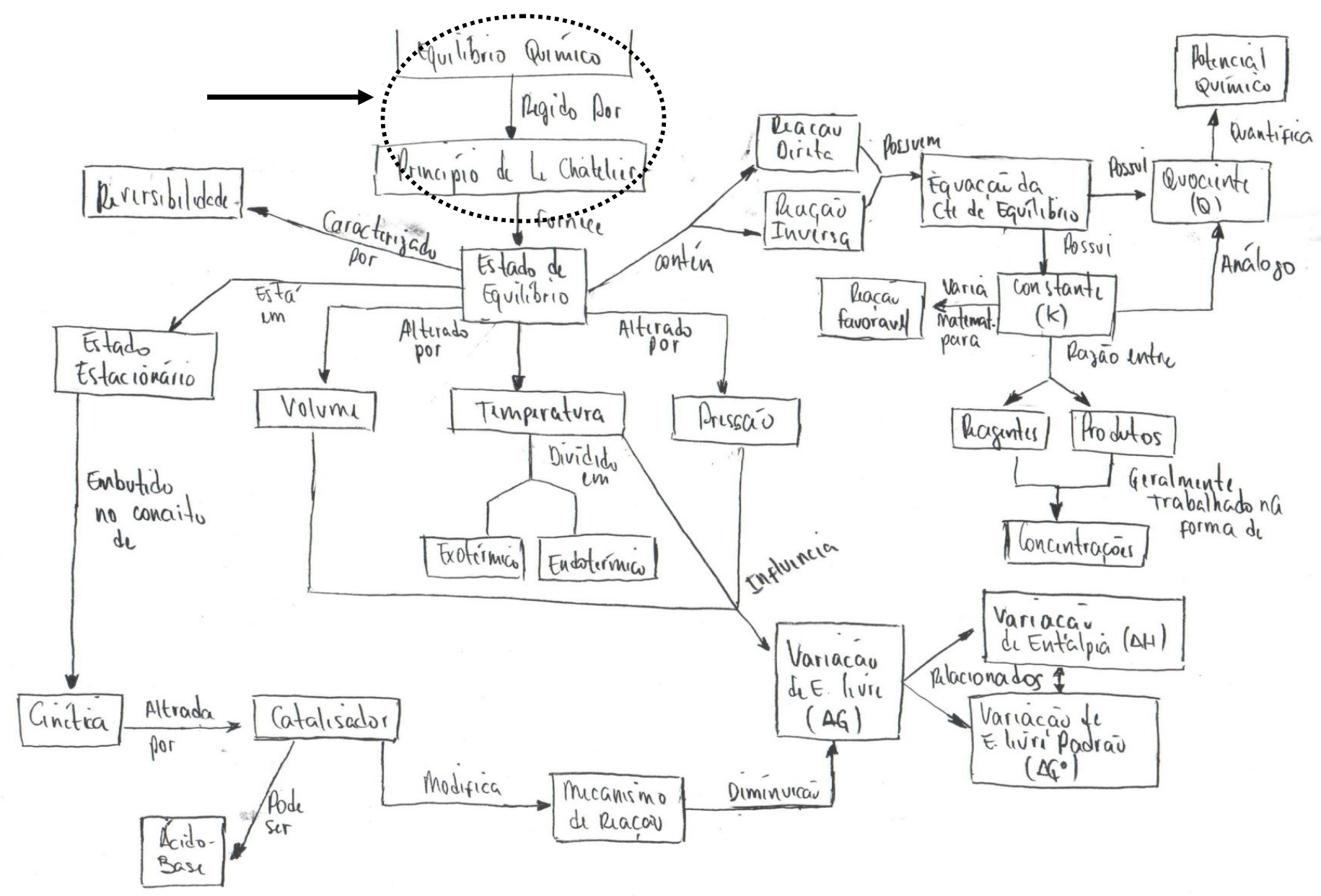

Figura 10-Mapa conceitual construído por aluno_11 do 3ํano de 2007 durante estudo piloto 


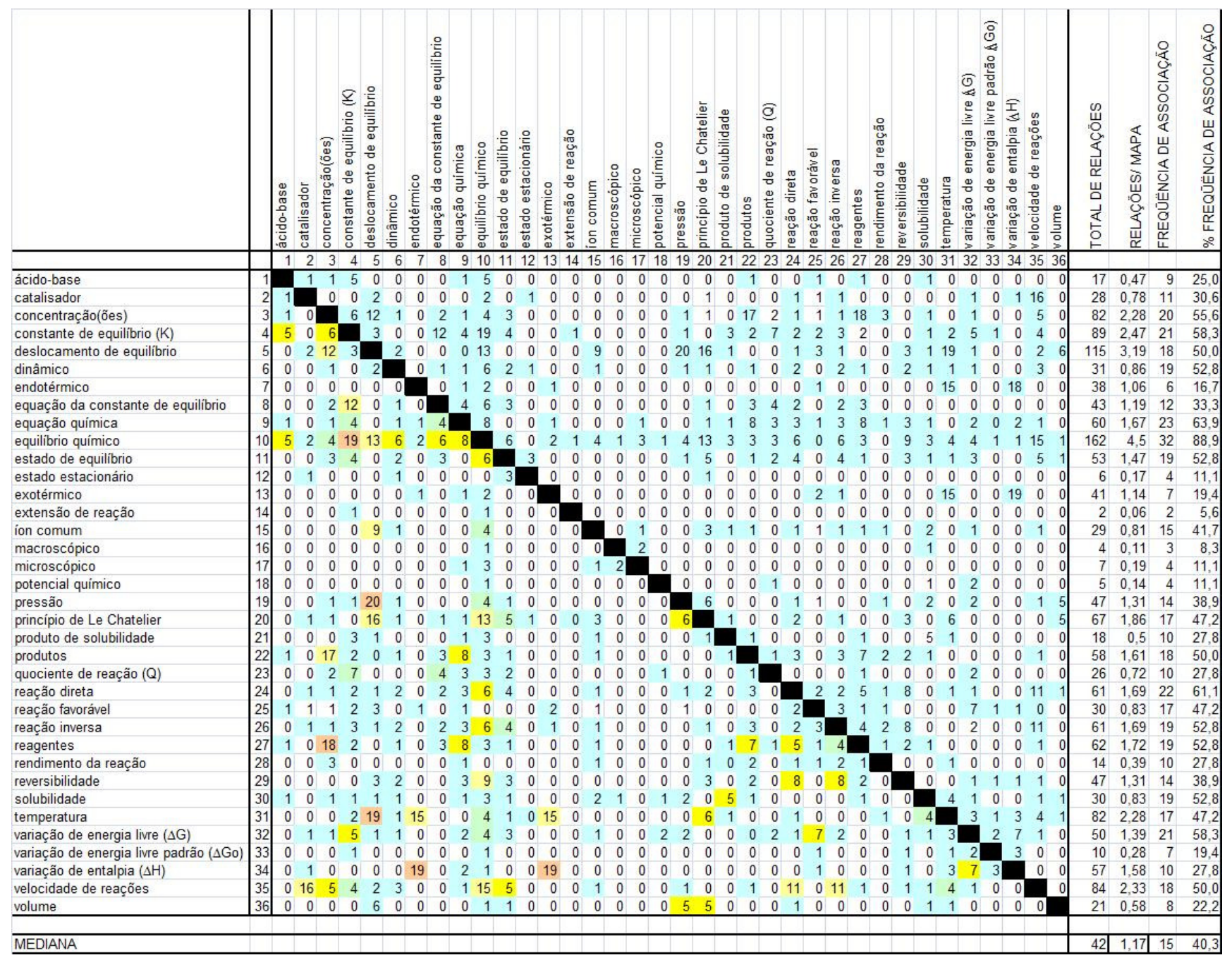

Figura 11-Matriz final obtida a partir da soma de todos os mapas conceituais elaborados pelos alunos do 30 ano do curso noturno. 


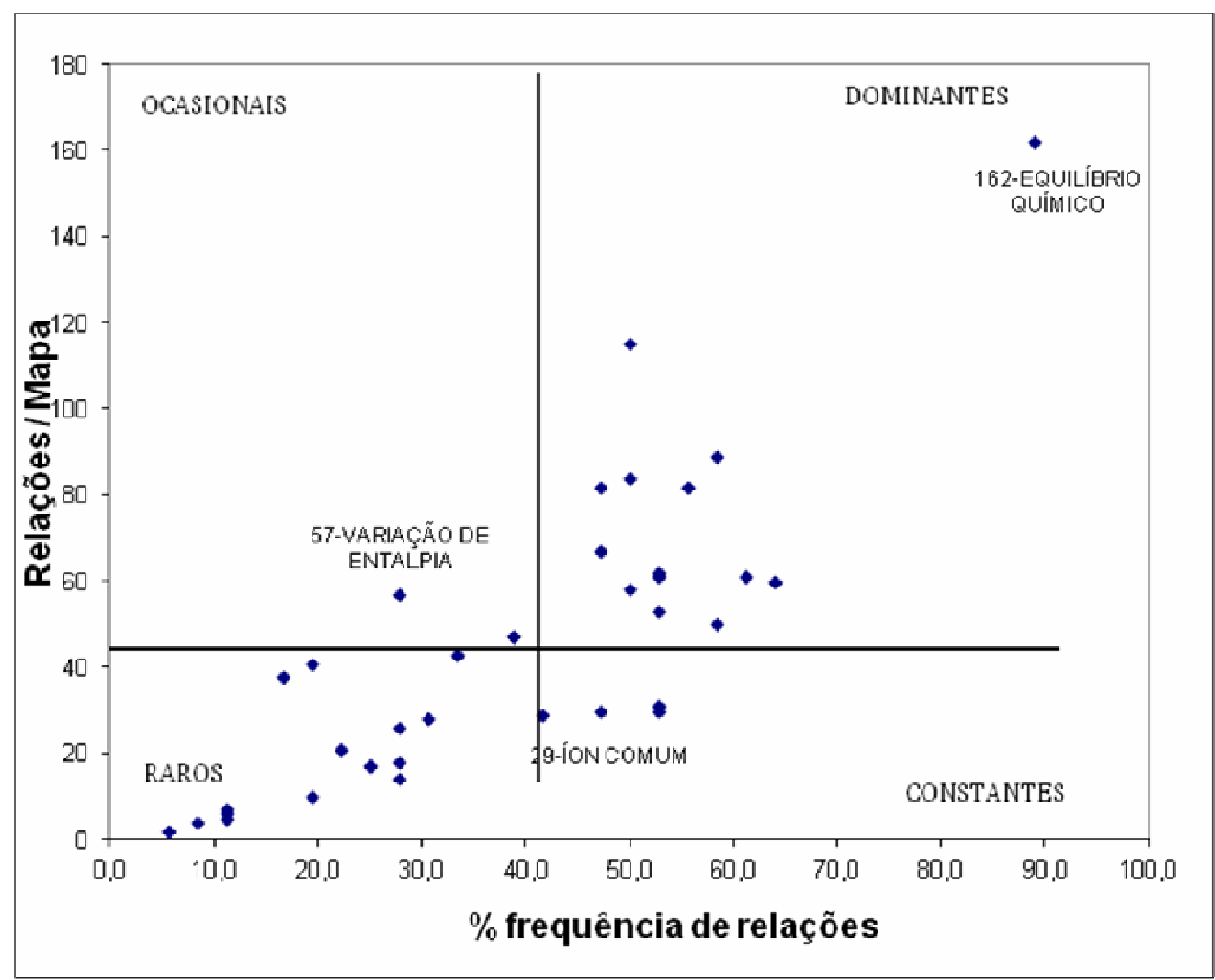

Figura 12-Gráfico obtido a partir da AMC para os alunos do 30 ano do curso noturno 


\section{- Construção de mapas conceituais representativos}

Ainda com o objetivo de comparar as duas amostras de alunos estudadas em 2007, estudo piloto, foi construído, a partir das matrizes finais, um mapa conceitual representativo para cada grupo. Construiu-se, a princípio, a partir das relações entre conceitos que apareceram em $50 \%, 30 \%$, e $15 \%$ ou mais dos mapas em cada uma das amostras.

Em seguida, com o auxílio das matrizes individuais, cada mapa que contém uma determinada relação é revisto e as frases de ligação utilizadas entre os dois conceitos em questão são listadas, agrupadas em categorias e computadas. Inicialmente foi feito um teste considerando as relações que apareciam em mais de $50 \%$ da amostra, no entanto, os mapas obtidos eram constituídos por grupos de conceitos isolados Figura 13. Também foram verificados mapas representativos com relações que apareciam em 30\% (Figura 14 e Figura 15), e 15\% da amostra.

Os mapas representativos com as relações acima de $30 \%$ da amostra, também, apareciam de maneira isolada dificultando assim a análise dos mesmos. O mesmo teste obtido com as relações acima de 15\% (Figura $16 \mathrm{e}$ Figura 17) da amostra demonstrou muitos conceitos relacionados, sendo assim difusa sua análise.

Foi efetuado então, o teste com o mapa representativo com um valor intermediário de $25 \%$ o qual demonstrou de maneira mais clara a ligação entre os conceitos, este foi escolhido de maneira a permitir a construção de um mapa com todos os conceitos ligados. Certamente há uma boa relação entre o valor escolhido e o número de conceitos presentes na lista de maneira que um número menor de conceitos deve permitir a adoção de um critério mais restrito. 


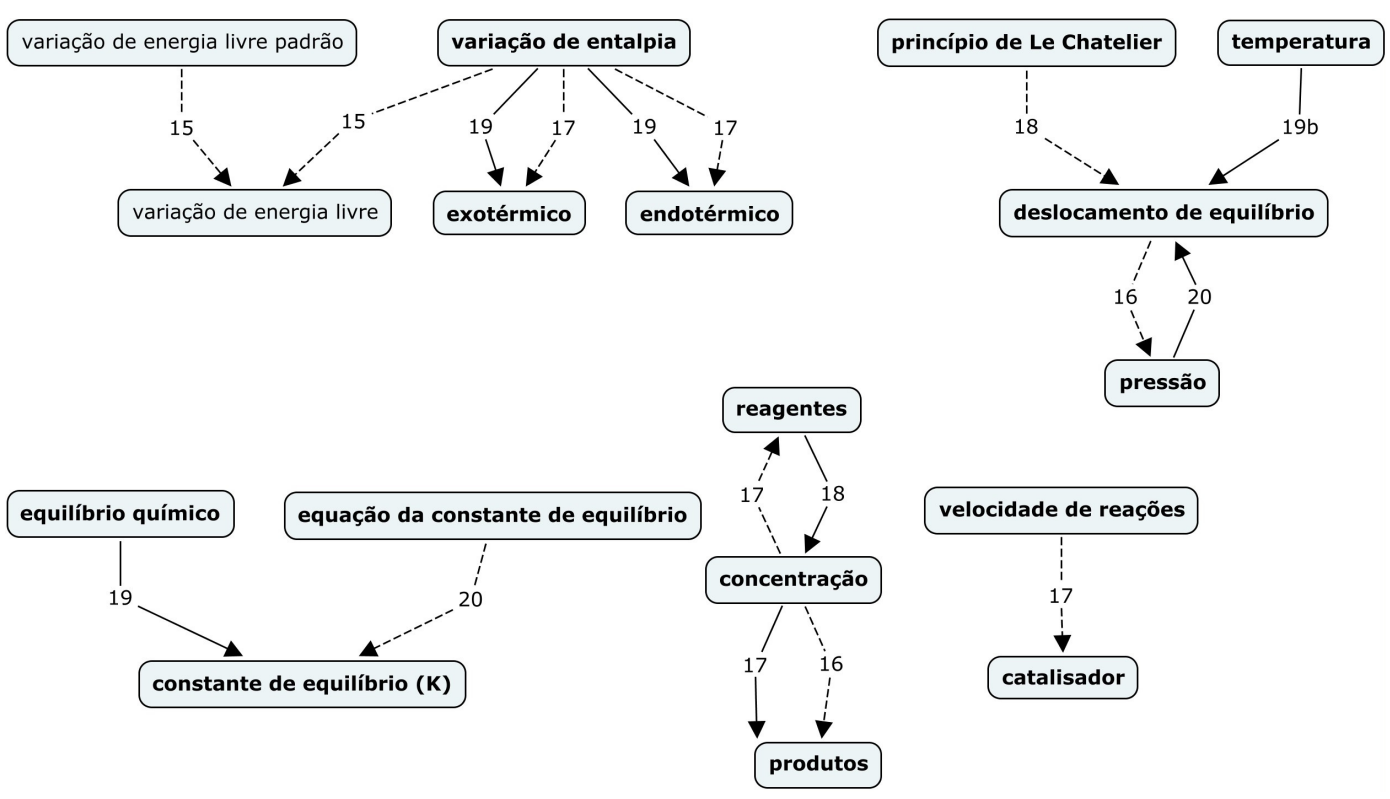

Figura 13- Mapa conceitual representativo-50\% para o grupo de alunos do curso integral. As linhas tracejadas representam as relações que são exclusivas desse mapa. Os valores representam o número de alunos que ligou os dois conceitos.

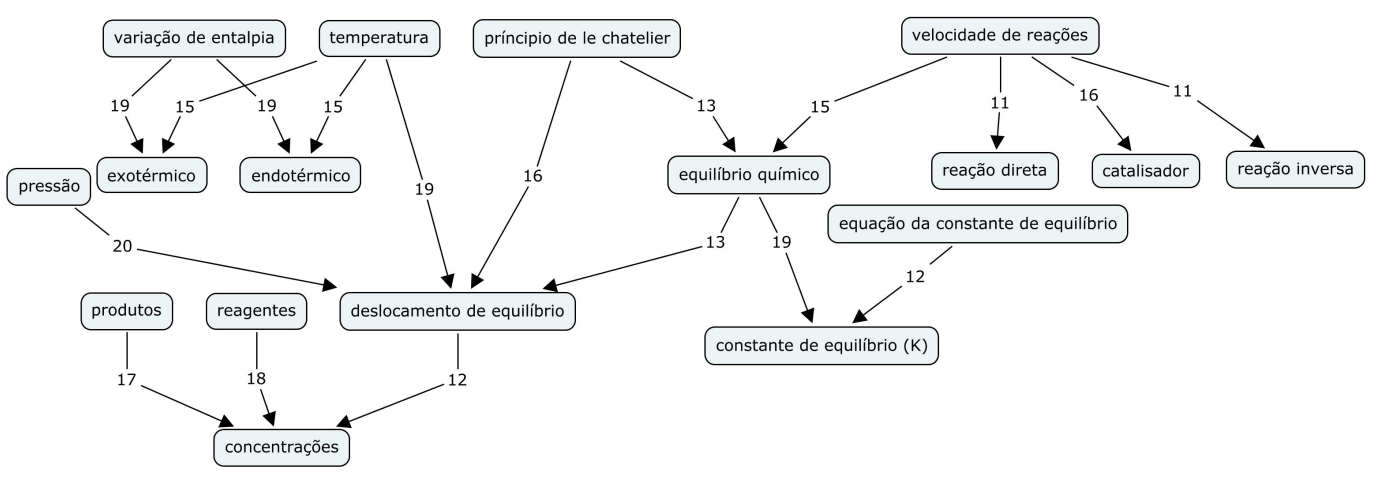

Figura 14-Mapa conceitual representativo-30\% para o grupo de alunos do curso noturno. Os valores representam o número de alunos que ligou os dois conceitos. 


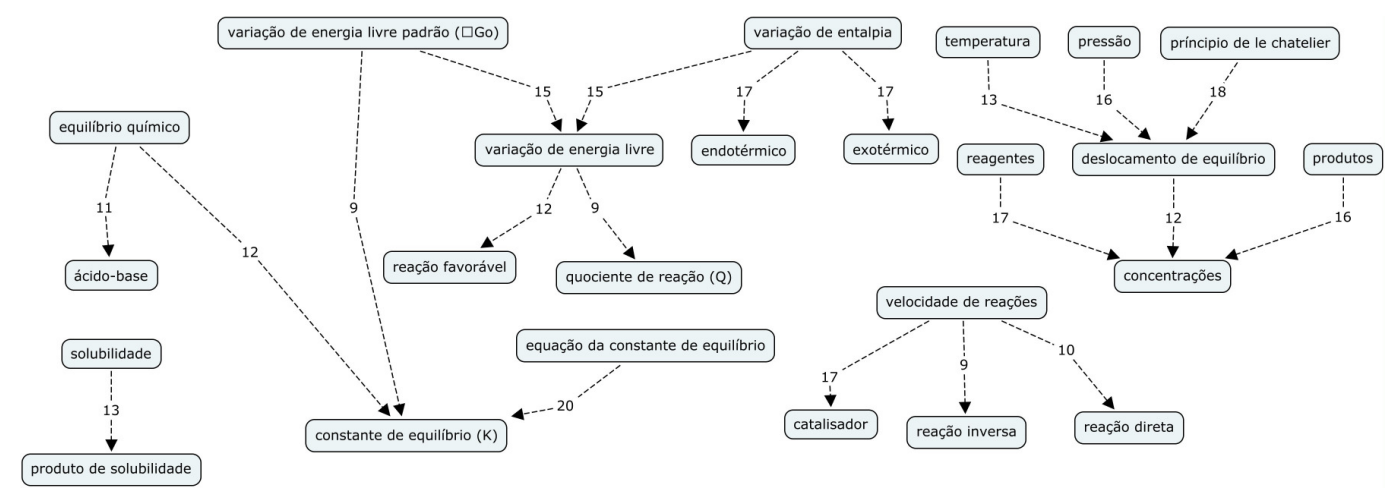

Figura 15-Mapa conceitual representativo- $30 \%$ para o grupo de alunos do curso integral. Os valores representam o número de alunos que ligou os dois conceitos.

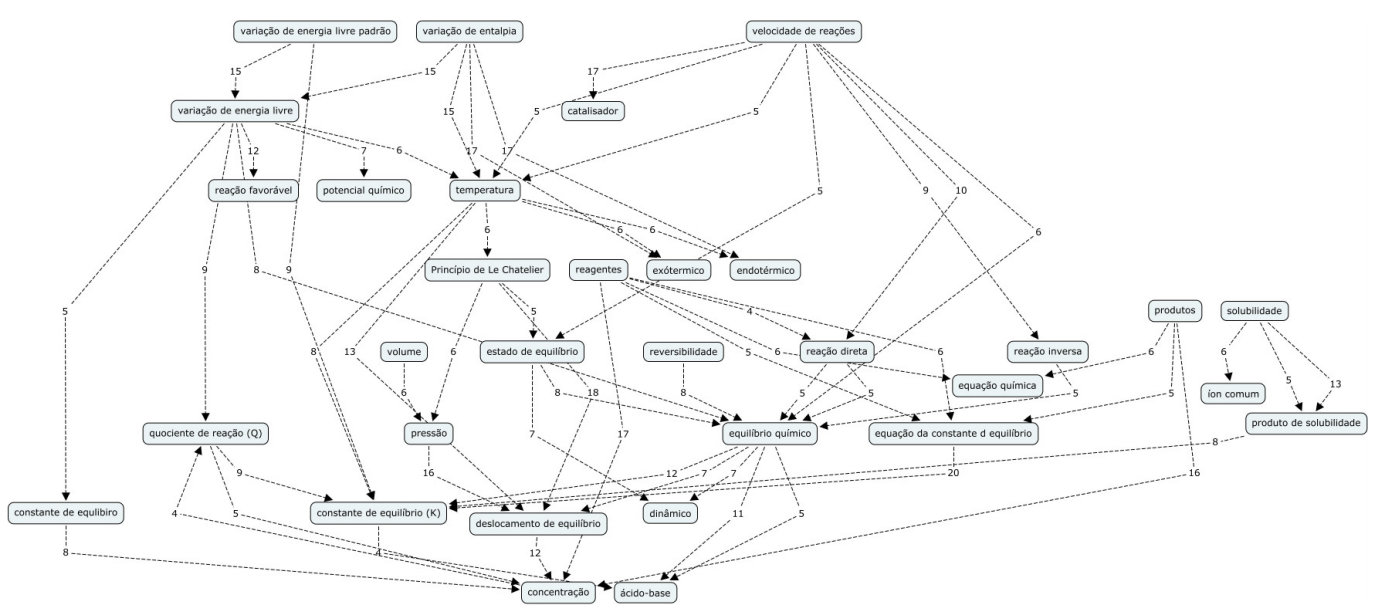

Figura 16-Mapa conceitual representativo-15\% para o grupo de alunos do curso integral. Os valores representam o número de alunos que ligou os dois conceitos. 


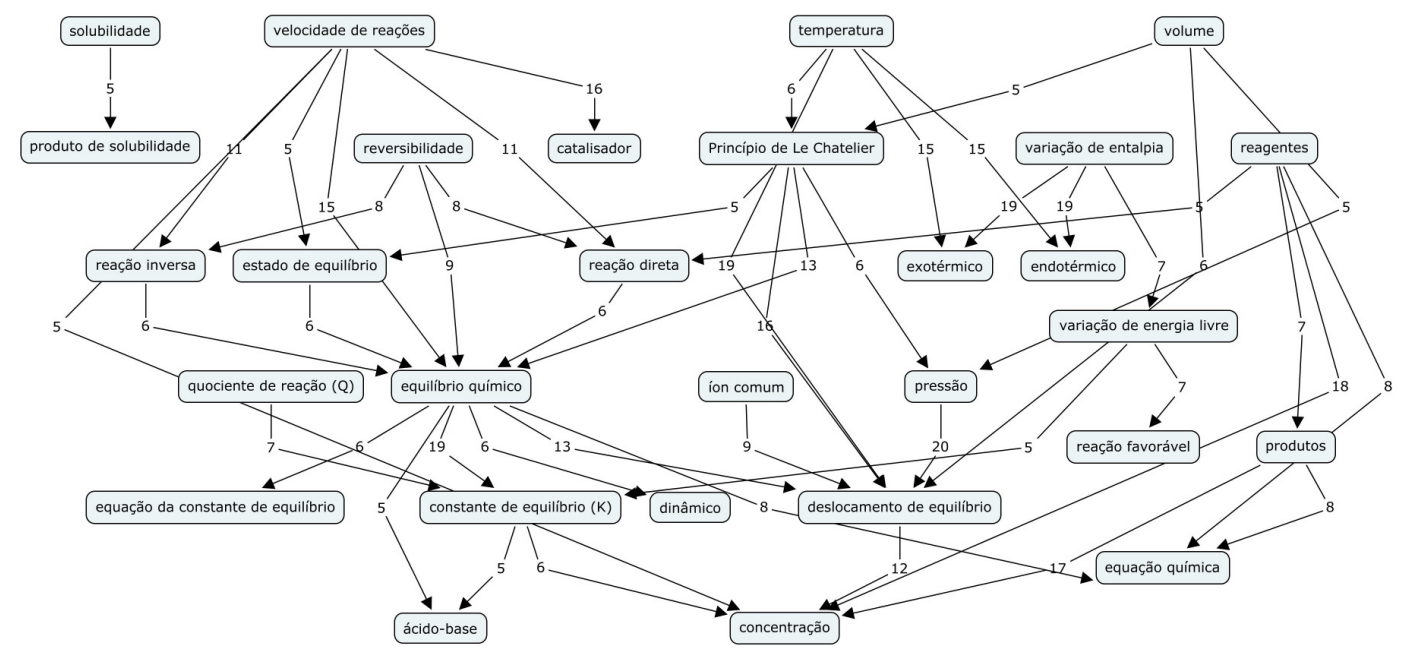

Figura 17-Mapa conceitual representativo-15\% para o grupo de alunos do curso noturno. Os valores representam o número de alunos que ligou os dois conceitos. 


\section{RESULTADOS E DISCUSSÃO}

\subsection{ESTUDO PILOTO: ANÁLISE GERAL DOS MAPAS CONCEITUAIS}

Nas Figura 18 a Figura 21 são apresentados, a título de ilustração, mapas elaborados pelos alunos do $3^{\circ}$ ano construídos em 2007. Observa-se desde mapas bem elaborados, ou seja, que demonstram um bom número de relações (Figura 18 e Figura 19) até mapas mais simples que podem demonstrar tanto a falta de uma compreensão completa do tema, como falta de dedicação do aluno na execução da atividade (Figura 20 e Figura 21).

Foram poucos os mapas que não apresentaram nenhuma frase de ligação compondo as proposições, sendo dois dos mapas dos alunos do período integral e quatro mapas dos alunos do noturno conforme exemplificado nas Figura 20 e Figura 21. Parte dos mapas apresenta uma estrutura mais linear, denotando poucas relações entre conceitos diferentes (Figura 21).

A análise desses mapas também mostrou que na maioria das vezes os mapas conceituais não apresentam uma hierarquia conceitual tão explícita, (Figura 20 e Figura 21), como exemplos, em que os conceitos mais gerais e inclusivos são colocados no topo do mapa, seguido pelos conceitos mais específicos e exemplos (Novak, 2006). Embora as instruções pedissem explicitamente que, antes de construir o mapa, os conceitos fossem listados em uma ordem hierárquica. Isto certamente se deve a vários fatores como a falta de experiência dos alunos em construir os mapas (formalmente este era o segundo mapa conceitual construído pelos mesmos), o elevado número de conceitos citados na lista e o tempo disponível para o trabalho.

A elaboração de um mapa hierárquico como na acepção de (Novak e Gowin, 1988) exige de quem o elabora clareza a respeito do grau de generalidade de cada conceito no contexto em que se está trabalhando, além, é claro, da capacidade de ver e expressar as diferentes relações entre os conceitos traduzida na forma de proposições relevantes e claras. Assim, é preciso que quem construa o mapa tenha a habilidade de trabalhar com estas duas dimensões: hierarquia e relação, habilidades que só são desenvolvidas 
com tempo e prática (Moreira, 1987). Ficou claro também que a construção de um mapa hierárquico envolvendo tantos conceitos, exige que o mesmo passe por um ou vários processos de re-elaboração, o que demandaria muito mais tempo e esforço e dificultaria a utilização desta metodologia no presente estudo. É também por esta razão que a metodologia de análise aqui desenvolvida e aplicada, não tem como foco a natureza estrutural dos mapas conceituais elaborados pelos alunos.

Além da hierarquia, é preciso se levar em conta as dificuldades que iniciantes têm com relação à construção das frases de ligação. A natureza sintética e a necessidade de clareza na elaboração da frase de ligação, exige de quem constrói um mapa uma certa experiência em fazê-lo. Este aspecto, já tem uma forte influência nos resultados aqui apresentados uma vez que a parte da metodologia aqui utilizada foca justamente na natureza das frases de ligação.

O fato dos alunos construírem o mapa em uma folha de papel pode também ser um fator limitante que leve o aluno a expressar um raciocínio mais linear, sem expressar todas as relações que o mesmo conheça.

De todo exposto e, uma vez que, não se dispõe de um tempo maior para submeter um determinado grupo de alunos às atividades de treinamento $e$ elaboração do mapa conceitual, o que também poderia cansar os alunos e poderia prejudicar os resultados, não se deve tomar estes mapas conceituais como cópia fiel e completa da estrutura conceitual do aluno a respeito do tema. O que na realidade é um objetivo inatingível uma vez que não há método suficientemente capaz de tal realização. No entanto, pode-se considerar que os mapas conceituais aqui apresentados expressam as relações mais significativas de um aluno estimulado por uma lista de conceitos envolvidos no tema.

Nas Figura 22 e Figura 23 são apresentadas as Matrizes finais obtidas a partir da soma de todos os mapas conceituais elaborados pelos alunos do terceiro ano do curso de bacharelado Integral e Noturno. Na Tabela 3 são apresentados os resultados obtidos utilizando a AEMC-Adaptada ( Figura 24 ) para os mapas conceituais elaborados em 2007. 
Pode-se constatar que é relevante a concordância (67\%) entre as classificações dos conceitos para os dois grupos de alunos, especialmente com relação aos conceitos dominantes e raros.

Conforme ilustrado na tabela 3 e Figura 24, observa-se uma dominância dos conceitos que estão relacionados às condições e à definição do estado de equilíbrio químico e às alterações desse estado (temperatura, concentrações, constante de equilíbrio, velocidades de reação, reação inversa e direta, deslocamento do equilíbrio e princípio de Le Chatelier). Entre conceitos classificados como raros estão exemplos (produto de solubilidade, ácido-base e estado estacionário) e conceitos relacionado à termodinâmica (variação de energia livre padrão $\left(\Delta G^{\circ}\right)$ ), potencial químico, endotérmico e exotérmico). Apesar de não serem dominantes, os conceitos quociente de reação e variação de energia livre $(\Delta G)$ apresentam alto valor de Relações $(R)$ nos dois grupos. 


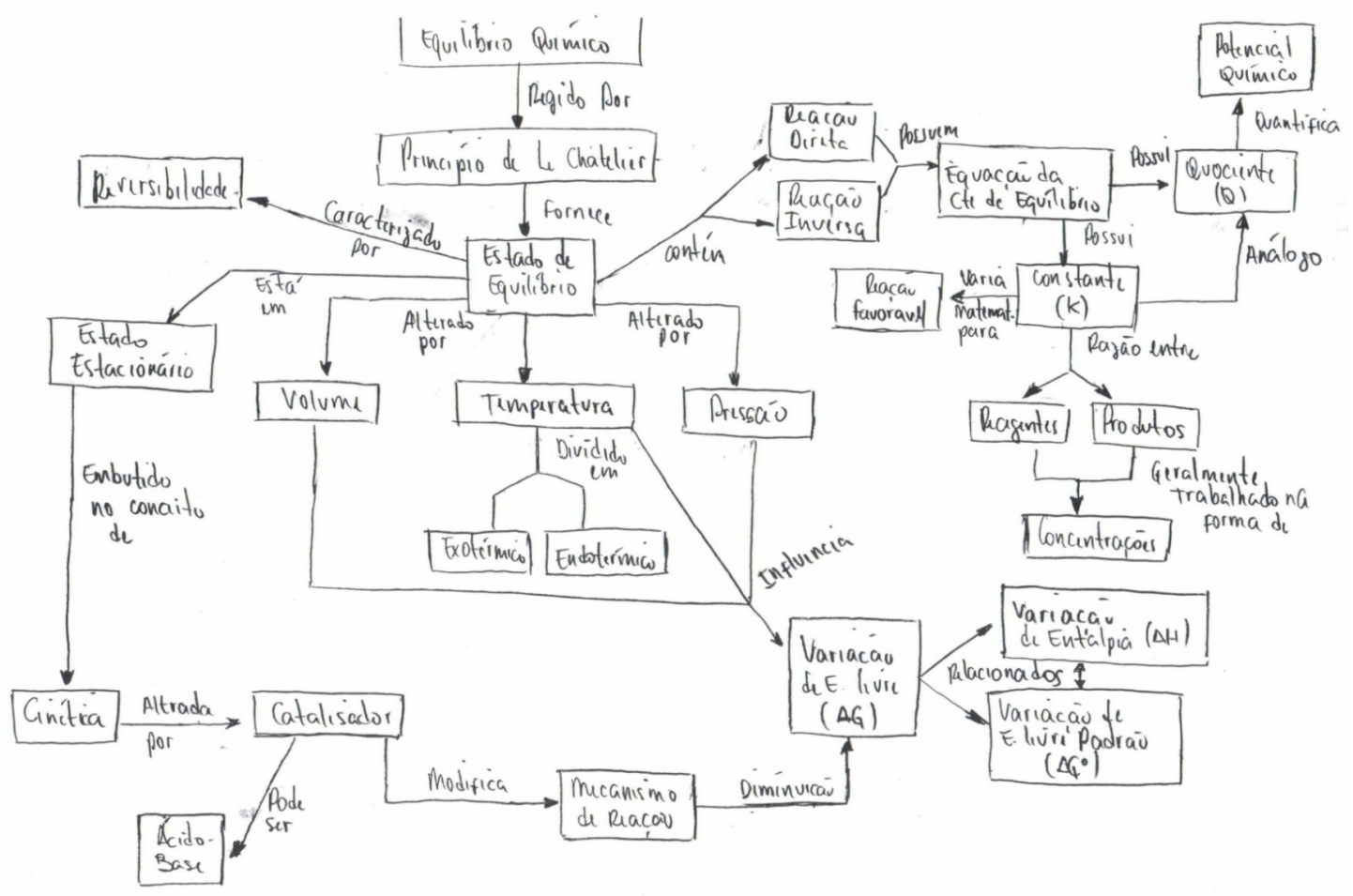

Figura 18- Mapa conceitual construído por aluno do 30 ano de 2007 


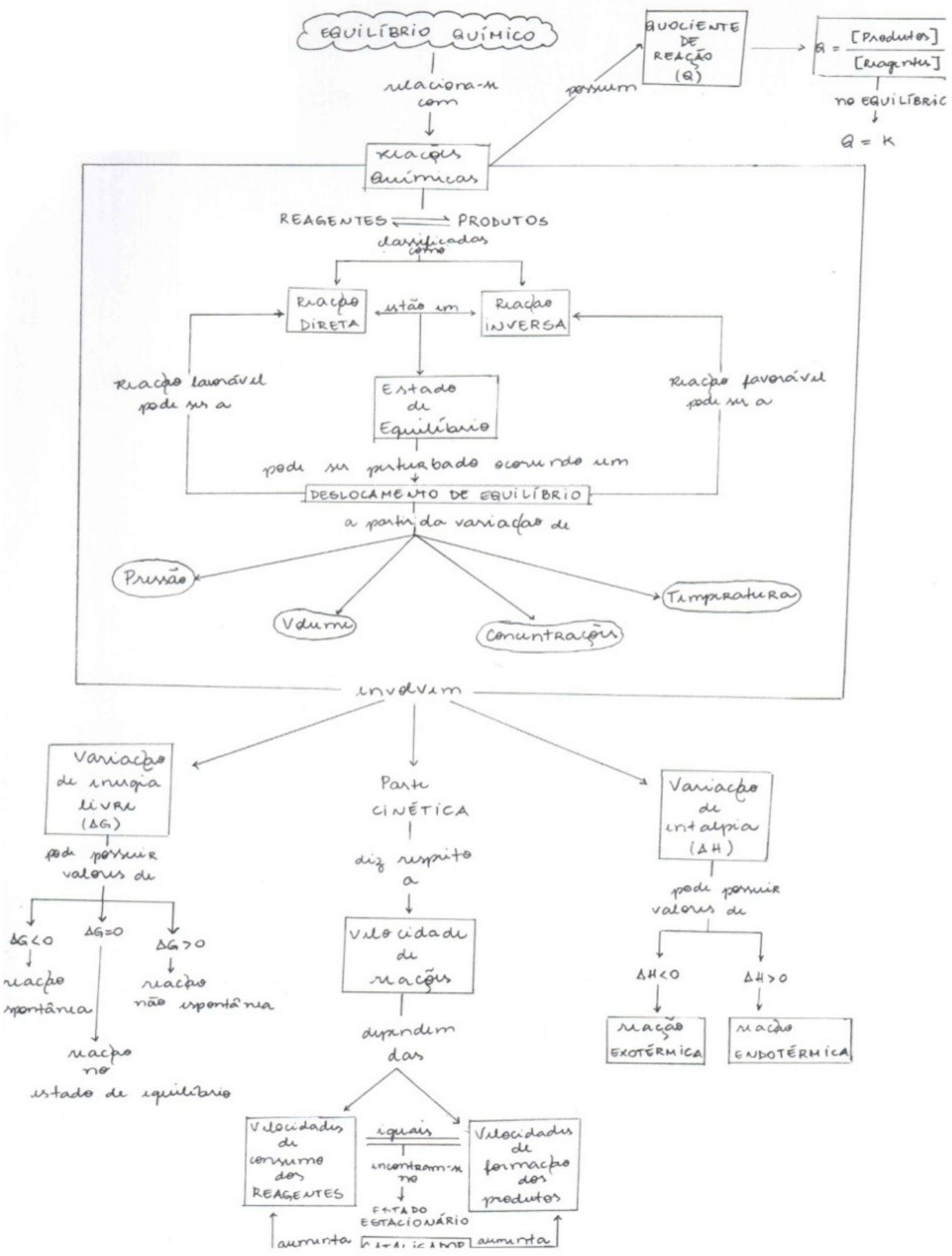

Figura 19- Mapa conceitual construído por aluno do $3^{\circ}$ ano de 2007. 


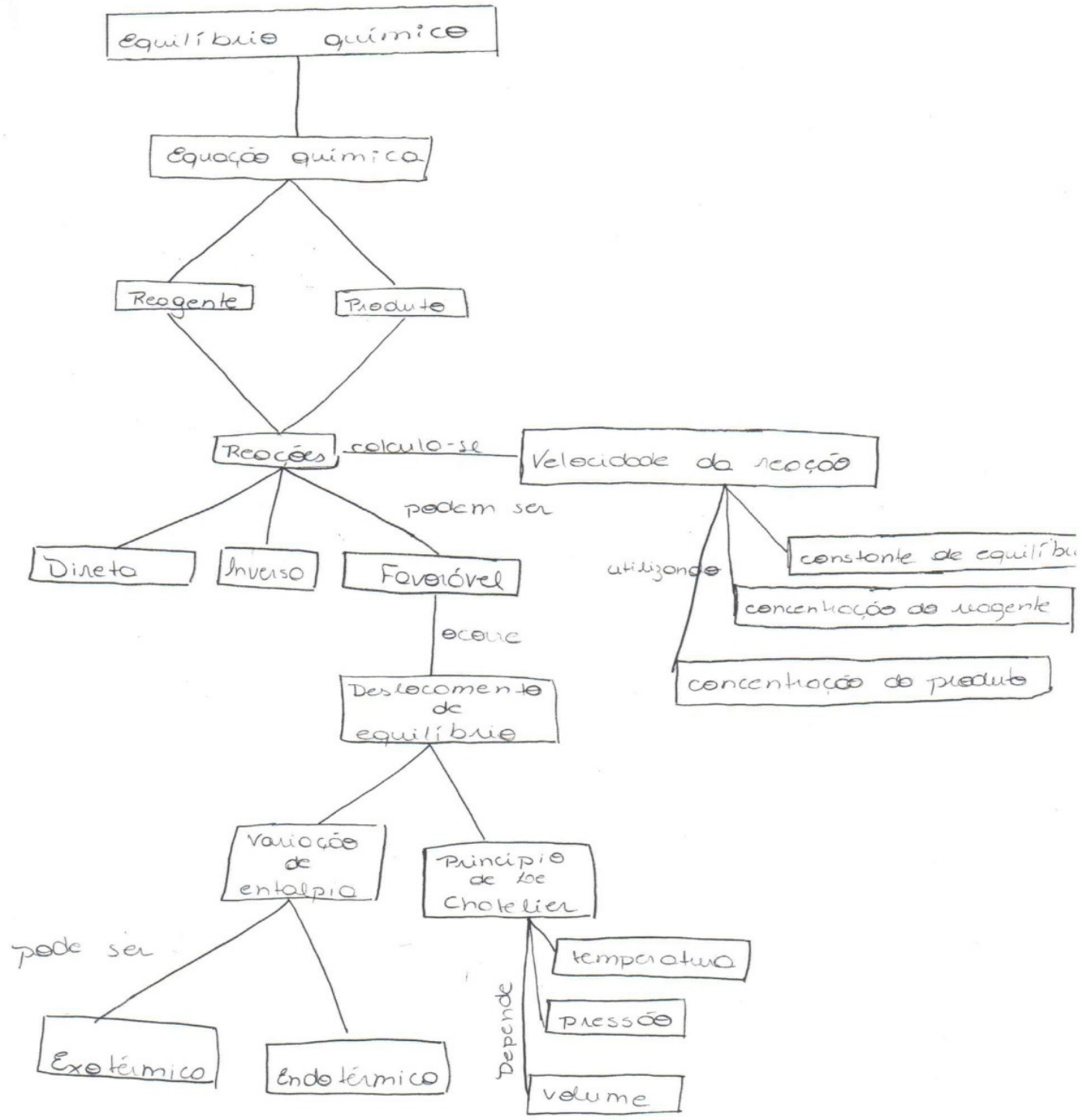

Figura 20- Mapa conceitual construído por aluno do 3ํaํ ano de 2007. 


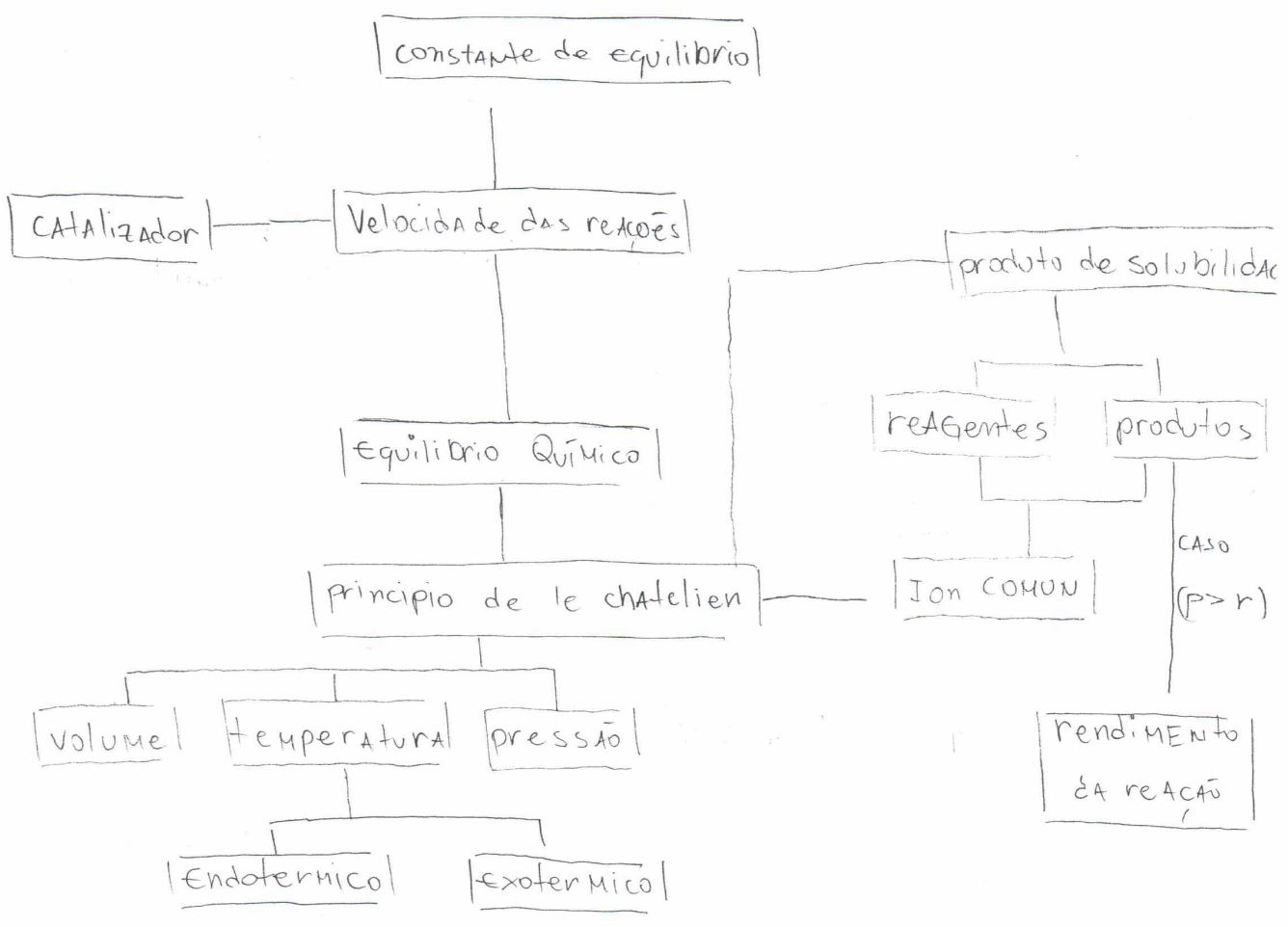

Figura 21- Mapa conceitual construído por aluno do 3ํano de 2007. 


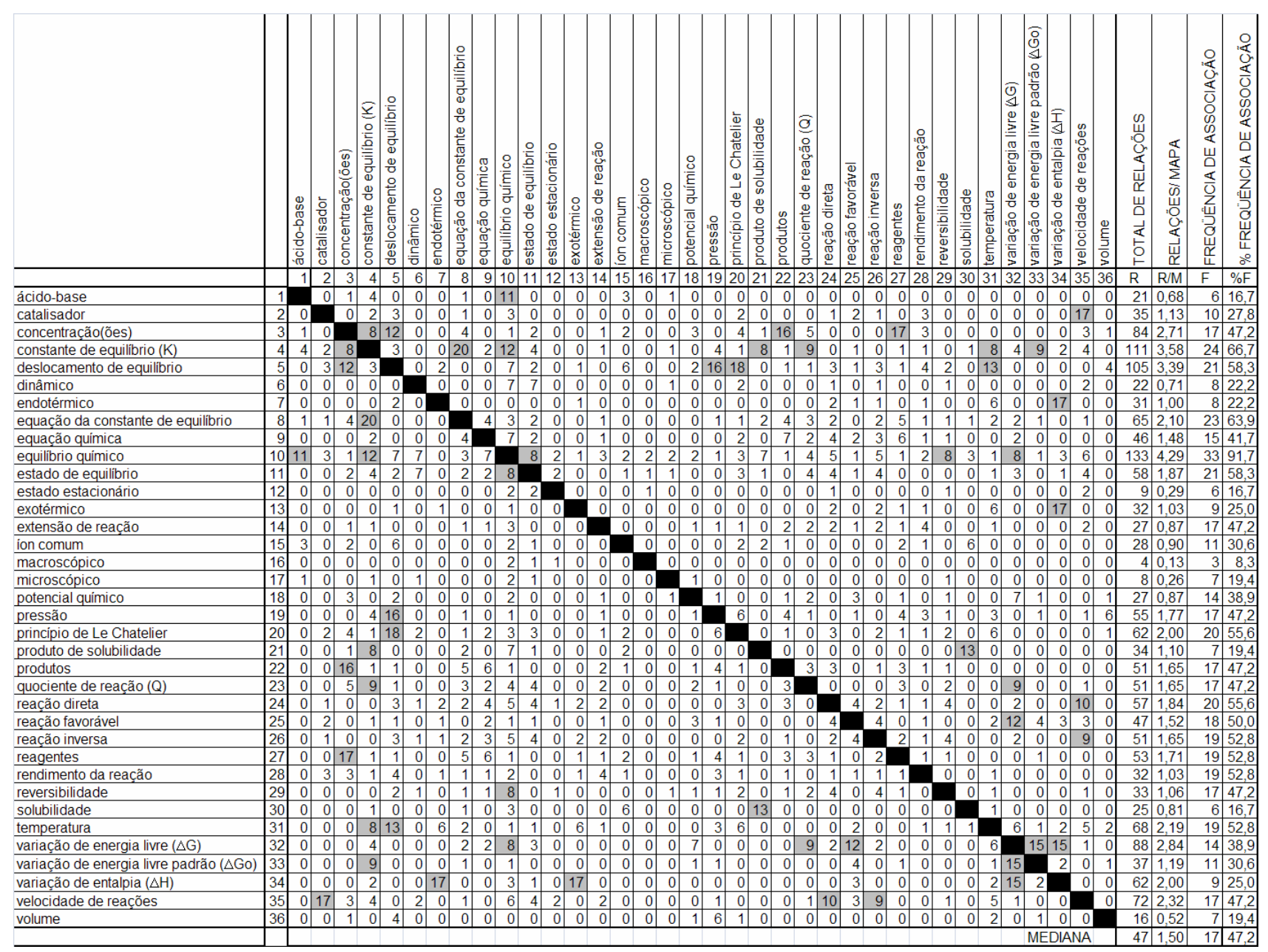

Figura 22 - Matriz final obtida a partir da soma de todos os mapas conceituais elaborados pelos alunos do $3^{\circ}$ ano do curso integral. 


\begin{tabular}{|c|c|c|c|c|c|c|c|c|c|c|c|c|c|c|c|c|c|c|c|c|c|c|c|c|c|c|c|c|c|c|c|c|c|c|c|c|c|c|}
\hline & & 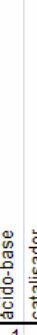 & & 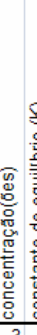 & 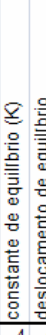 & 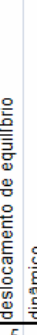 & & 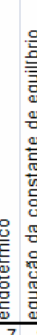 & & 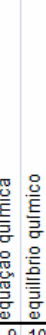 & 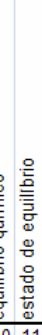 & 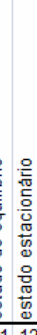 & 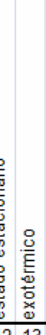 & 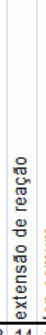 & E & $\begin{array}{l}\stackrel{\circ}{\circ} \\
: \\
:\end{array}$ & $\frac{.}{8}$ & 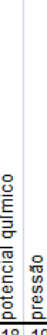 & 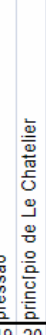 & 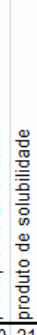 & 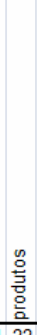 & 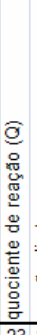 & 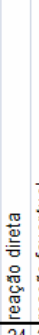 & 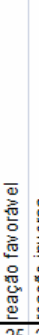 & 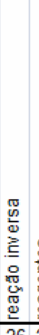 & 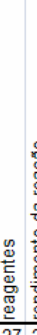 & 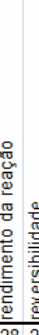 & 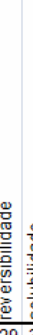 & & ב⿺ & 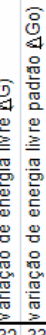 & 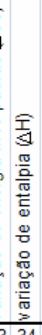 & 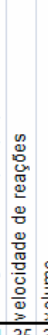 & 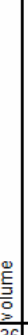 & 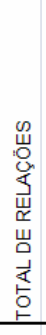 & 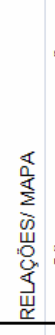 & 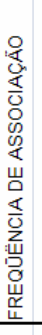 & 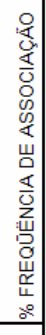 \\
\hline & & 1 & 2 & 3 & 4 & 5 & 6 & 7 & 8 & 910 & $0 \quad 11$ & 112 & 213 & 14 & 151 & 161 & 171 & 1819 & 920 & 021 & 22 & 23 & 24 & 252 & 262 & & 282 & 293 & & 313 & 3233 & 334 & 353 & 36 & & & & \\
\hline ácido-base & 1 & & 1 & 1 & 5 & 0 & 0 & 0 & 0 & 15 & 50 & 00 & $\begin{array}{ll}0 & 0\end{array}$ & 0 & 0 & 0 & 0 & 00 & $\begin{array}{ll}0 & 0\end{array}$ & 00 & 1 & 0 & 0 & 1 & 0 & 1 & 0 & 0 & 1 & 0 & 00 & 00 & 0 & 0 & 17 & 0,47 & 9 & 25,0 \\
\hline catalisador & 2 & & & & 0 & 2 & 0 & 0 & 0 & 0 & 20 & 0 & 1 & 0 & 0 & 0 & 0 & 0 & 0 & 1 & 0 & 0 & 1 & 1 & 1 & 0 & 0 & 0 & 0 & 0 & 1 & 0 & 16 & & 28 & 0,78 & 11 & 0,6 \\
\hline concentração(ões) & 3 & 1 & 0 & & 61 & 12 & 1 & 0 & 2 & 14 & 4 & 3 & 0 & 0 & 0 & 0 & 0 & 0 & 1 & 1 & 17 & 2 & 1 & 1 & & 18 & 3 & 0 & 1 & 0 & 1 & 0 & 5 & & 82 & 2,28 & 20 & 5,6 \\
\hline te de equilibrio (K) & 4 & 5 & & & & 3 & 0 & 01 & 12 & 419 & 9 & 4 & 0 & 1 & 0 & 0 & 0 & 0 & 10 & 0 & 2 & 7 & 2 & 2 & 3 & 2 & 0 & 0 & & 2 & 5 & 0 & 4 & & 89 & 2,47 & 21 & 8,3 \\
\hline deslocamento de equ & 5 & 0 & 21 & & 3 & & 2 & 0 & 0 & 013 & 3 & 0 & 0 & 0 & 9 & 0 & 0 & 020 & 2016 & 6 & 0 & 0 & 1 & 3 & 1 & 0 & 0 & 3 & & 19 & 1 & 0 & 2 & & 115 & 3,19 & 18 & 50,0 \\
\hline dinâmi & 6 & 0 & 0 & 1 & 0 & 2 & & 0 & 1 & 16 & 6 & 2 & 1 & 0 & 1 & 0 & 0 & 01 & 11 & 1 & 1 & 0 & 2 & 0 & 2 & 1 & 0 & 2 & & 1 & 1 & 0 & 3 & & 31 & 0,86 & 19 & 52,8 \\
\hline endotérmico & 7 & 0 & 0 & 0 & 0 & 0 & 0 & & 0 & 1 & 2 & 0 & 0 & 0 & 0 & 0 & 0 & 0 & 0 & 0 & 0 & 0 & 0 & 1 & 0 & 0 & 0 & 0 & & 15 & 0 & 018 & 0 & & 38 & ,06 & & 16,7 \\
\hline constante de equilibrio & 8 & 0 & 0 & & 12 & 0 & 1 & 0 & & 4 & 6 & 3 & 0 & 0 & 0 & 0 & 0 & 0 & 0 & 1 & 3 & 4 & 2 & 0 & 2 & 3 & 0 & 0 & 0 & 0 & 0 & 00 & 0 & & 43 & 1,19 & 12 & 33,3 \\
\hline equação química & 9 & 1 & 0 & & 4 & 0 & 1 & 1 & 4 & & 8 & 0 & 0 & 10 & 0 & 0 & 1 & 0 & $\begin{array}{ll}0 & 1\end{array}$ & 1 & 8 & 3 & 3 & 1 & 3 & 8 & 1 & 3 & 1 & 0 & 2 & 2 & 1 & 0 & 60 & 1,67 & 23 & 63,9 \\
\hline equilibrio químic & 10 & 5 & 2 & & 191 & 13 & 6 & 2 & 6 & 8 & & 6 & 0 & 1 & 4 & 1 & 3 & 1 & 413 & 3 & 3 & 3 & 6 & 0 & 6 & 3 & 0 & 9 & 3 & 4 & 4 & & 15 & & 162 & 4,5 & 32 & 38,9 \\
\hline estad & 11 & 0 & 0 & 3 & 4 & 0 & 2 & 0 & 3 & 0 & 6 & 3 & 3 & 0 & 0 & 0 & 0 & 0 & 15 & 5 & 1 & 2 & 4 & 0 & 4 & 1 & 0 & 3 & 1 & 1 & 3 & 0 & 5 & & 53 & 1,47 & 19 & 52,8 \\
\hline stacionário & 12 & 0 & 1 & 0 & 0 & 0 & 1 & 0 & 0 & 0 & 03 & 3 & 0 & 0 & 0 & 0 & 0 & 0 & 0 & 1 & 0 & 0 & 0 & 0 & 0 & 0 & 0 & 0 & & 0 & 0 & 0 & 0 & & 6 & 0,17 & 4 & 11,1 \\
\hline exotér & 13 & 0 & 0 & 0 & 0 & 0 & 0 & 1 & 0 & 1 & 0 & 00 & 0 & 0 & 0 & 0 & 0 & 0 & 0 & 0 & ) & 0 & 0 & 2 & 1 & 0 & 0 & 0 & & 15 & 0 & 019 & 0 & & 41 & 1,14 & & 19,4 \\
\hline extensão de reação & 14 & 0 & 0 & 0 & 1 & 0 & 0 & 0 & 0 & 0 & 1 & 0 & 0 & 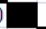 & 0 & 0 & 0 & 0 & 0 & 0 & 0 & 0 & 0 & 0 & 0 & 0 & 0 & 0 & & 0 & 0 & 00 & 0 & & 2 & 0,06 & & 5,6 \\
\hline ín co & 15 & 0 & 0 & 0 & 0 & 9 & 1 & 0 & 0 & 0 & 4 & 0 & 0 & 0 & & 0 & 1 & 0 & 0 & 3 & 1 & 0 & 1 & 1 & 1 & 1 & 1 & 0 & 2 & 0 & 1 & 0 & 1 & & 29 & 0,81 & 15 & 41,7 \\
\hline macroscópico & 16 & 0 & 0 & 0 & 0 & 0 & 0 & 0 & 0 & 0 & 1 & 0 & 0 & 0 & 0 & 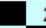 & 2 & 0 & 0 & 0 & 0 & 0 & 0 & 0 & 0 & 0 & 0 & 0 & 1 & 0 & 0 & 0 & 0 & & 4 & 0,11 & 3 & 8,3 \\
\hline microscópico & 17 & 0 & 0 & 0 & 0 & 0 & 0 & 0 & 0 & 1 & 30 & 0 & 0 & 0 & 1 & 2 & & 0 & 0 & 0 & 0 & 0 & 0 & 0 & 0 & 0 & 0 & 0 & 0 & 0 & 0 & 0 & 0 & & 7 & 0,19 & & 11,1 \\
\hline potenc & 18 & 0 & 0 & 0 & 0 & 0 & 0 & 0 & 0 & 0 & 10 & 0 & 0 & 0 & 0 & 0 & 0 & & 0 & 0 & 0 & 1 & 0 & 0 & 0 & 0 & 0 & 0 & 1 & 0 & 2 & 0 & 0 & & 5 & 0,14 & & 11,1 \\
\hline press & 19 & 0 & 0 & 1 & 12 & 20 & 1 & 0 & 0 & 04 & $4 \quad 1$ & 1 & 0 & 0 & 0 & 0 & 0 & 0 & & 6 & 0 & 0 & 1 & 1 & 0 & 0 & 1 & 0 & 2 & 0 & 2 & 0 & 1 & & 47 & 1,31 & 14 & 38,9 \\
\hline princí & 20 & 0 & 1 & 1 & & 16 & 1 & 0 & 1 & 113 & $\begin{array}{ll}3 & 5\end{array}$ & 5 & 1 & 0 & 3 & 0 & 0 & 0 & 6 & 1 & 0 & 0 & 2 & 0 & 1 & 0 & 0 & 3 & 0 & 6 & 0 & 0 & 0 & & 7 & 1,86 & 17 & 47,2 \\
\hline produto de & 21 & 0 & 0 & 0 & 3 & 1 & 0 & 0 & 0 & 13 & $\begin{array}{ll}3 & 0\end{array}$ & 0 & 0 & 0 & 1 & 0 & 0 & 0 & 0 & 1 & 1 & 0 & 0 & 0 & 0 & 1 & 0 & 0 & 5 & 1 & 0 & 0 & 0 & & 18 & 0,5 & 10 & 27,8 \\
\hline produtos & 22 & 1 & 01 & 17 & 2 & 0 & 1 & 0 & 3 & 8 & $\begin{array}{ll}3 & 1\end{array}$ & 1 & 0 & 0 & 1 & 0 & 0 & 0 & 0 & 0 & & & 3 & 0 & 3 & 7 & 2 & 2 & 1 & 0 & 0 & 0 & 1 & & 58 & 1,61 & 18 & 50,0 \\
\hline quocie & 23 & 0 & 0 & 2 & 7 & 0 & 0 & 0 & 4 & 3 & 32 & 2 & 0 & 0 & 0 & 0 & 0 & 1 & 0 & & & & 0 & 0 & 0 & 1 & 0 & 0 & 0 & 0 & 2 & 0 & 0 & & 26 & 0,72 & 10 & 27,8 \\
\hline reação d & 24 & 0 & 1 & 1 & 2 & 1 & 2 & 0 & 2 & 3 & $\begin{array}{ll}6 & 4\end{array}$ & 4 & 0 & 0 & 1 & 0 & 0 & 0 & 1 & & 3 & 0 & & 2 & 2 & 5 & 1 & 8 & 0 & 1 & 1 & & 11 & & 1 & 1,69 & 2 & 61,1 \\
\hline reação f & 25 & 1 & 1 & 1 & 2 & 3 & 0 & 1 & 0 & 1 & 00 & 0 & 2 & 0 & 1 & 0 & 0 & 0 & 1 & 0 & & 0 & 2 & & 3 & 1 & 1 & 0 & 0 & 0 & 7 & 1 & 0 & & 30 & 0,83 & 17 & 47,2 \\
\hline reação inversa & 26 & 0 & 1 & 1 & 3 & 1 & 2 & 0 & 2 & 3 & $\begin{array}{ll}6 & 4\end{array}$ & 4 & 0 & 0 & 1 & 0 & 0 & 0 & 0 & 1 & & 0 & 2 & 3 & & 4 & 2 & 8 & 0 & 0 & 2 & 0 & 11 & & 61 & 1,69 & 19 & 52,8 \\
\hline reag & 27 & 1 & 01 & 18 & 2 & 0 & 1 & 0 & 3 & 8 & 31 & 1 & 0 & 0 & 1 & 0 & 0 & 0 & 0 & 0 & & 1 & & 1 & 4 & & & 2 & 1 & 0 & 0 & 0 & 1 & & 2 & 1,72 & 19 & 2,8 \\
\hline rendit & 28 & 0 & 0 & 3 & 0 & 0 & 0 & 0 & 0 & 10 & 00 & 0 & 0 & 0 & 1 & 0 & 0 & 0 & & 0 & & 0 & & & & & & 0 & 0 & 1 & 0 & 0 & 0 & & & 0,39 & & 27,8 \\
\hline reversibilidade & 29 & 0 & 0 & 0 & 0 & 3 & 2 & 0 & 0 & 39 & 93 & 3 & 0 & 0 & 0 & 0 & 0 & 0 & 0 & 3 & ) & 0 & 8 & 0 & 8 & 2 & 0 & & 0 & 0 & 1 & 11 & 1 & & 47 & 1,31 & 14 & 38,9 \\
\hline solubi & 30 & 1 & 0 & 1 & 1 & 1 & 1 & 0 & 0 & 13 & $\begin{array}{ll}3 & 1\end{array}$ & 1 & $\begin{array}{ll}0 & 0\end{array}$ & 0 & 2 & 1 & 0 & 1 & 20 & 0 & 5 & 0 & 0 & 0 & 0 & 1 & 0 & 0 & & & 1 & 0 & 1 & & 30 & 0,83 & 19 & 52,8 \\
\hline & 3 & 0 & 0 & 0 & 21 & 19 & 11 & 15 & 0 & 0 & 4 & 1 & 015 & 50 & 0 & 0 & 0 & 0 & 0 & 6 & & 0 & 1 & 0 & & & 1 & & 4 & & & 3 & 4 & & 2 & 28 & 17 & 7,2 \\
\hline & 3 & 0 & 1 & 1 & 5 & 1 & 1 & 0 & 0 & 2 & $4 \quad 3$ & 3 & 00 & 0 & 1 & 0 & 0 & 2 & 2 & 0 & 0 & 2 & 1 & 7 & 2 & 0 & 0 & 1 & & 3 & & 7 & 1 & & 50 & 1,39 & 21 & 58,3 \\
\hline variação de energia livre padrão $(\Delta \mathrm{Go})$ & 33 & 0 & 0 & 0 & 1 & 0 & 0 & 0 & 0 & 0 & 10 & 0 & $\begin{array}{ll}0 & 0\end{array}$ & 0 & 0 & 0 & 0 & 0 & 00 & 0 & 0 & 0 & 0 & 1 & 0 & 0 & 0 & 1 & 0 & 1 & 2 & & 0 & & 10 & 0,28 & 7 & 19,4 \\
\hline variaçâ & 34 & 0 & 1 & 0 & 0 & 0 & 01 & 19 & 0 & & 10 & 0 & 019 & 0 & 0 & 0 & 0 & 0 & 0 & 0 & & 0 & 0 & & 0 & 0 & 0 & 1 & 0 & 3 & 7 & & & & 57 & 1,58 & 10 & 27,8 \\
\hline velocidac & 35 & 01 & 16 & 5 & 4 & 2 & 3 & 0 & 0 & 115 & & 5 & $\begin{array}{ll}0 & 0\end{array}$ & 0 & 1 & 0 & 0 & 0 & 10 & 0 & & & 11 & & 11 & 1 & 0 & & & 4 & 1 & 0 & & & 34 & 33 & 18 & 50,0 \\
\hline volume & 36 & 0 & 0 & 0 & 0 & 6 & 0 & 0 & 0 & $\begin{array}{ll}0 & 1\end{array}$ & $\begin{array}{ll}1 & 1\end{array}$ & 1 & 0 & 0 & 0 & 0 & 0 & 0 & $\begin{array}{ll}5 & 5 \\
\end{array}$ & 5 & 0 & 0 & 1 & 0 & 0 & 0 & 0 & 0 & 1 & 1 & 0 & 0 & 0 & & 21 & 0,58 & 8 & 22,2 \\
\hline MEDIANA & & & & & & & & & & & & & & & & & & & & & & & & & & & & & & & & & & & 42 & 1.17 & 15 & 40,3 \\
\hline
\end{tabular}

Figura 23 - Matriz final obtida a partir da soma de todos os mapas conceituais elaborados pelos alunos do $3^{\circ}$ ano do curso noturno. 


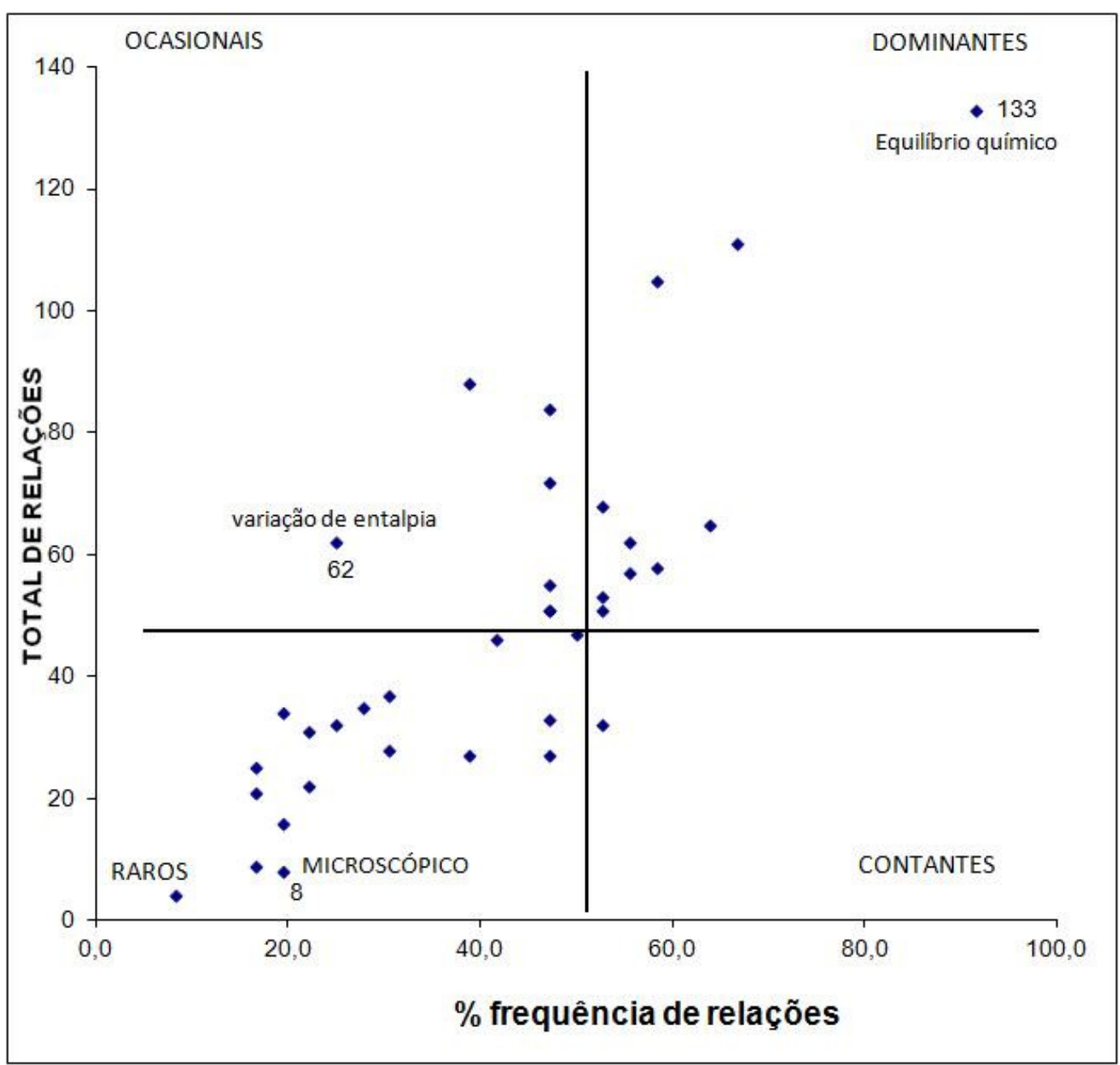

Figura 24 - Gráfico obtido a partir da AEMC para os alunos do $3^{\circ}$ ano do curso integral. Prova de Associação de Olmstead-Tukey para a matriz soma dos mapas conceituais elaborados pelos alunos do período integral. Cada ponto corresponde a um conceito não está identificado para facilitar a visualização. 
Tabela 3- Resultados obtidos usando AEMC para os dados obtidos em 2007

\begin{tabular}{|c|c|c|c|}
\hline $\begin{array}{l}\text { Conceitos } \\
\text { dominantes }\end{array}$ & $\begin{array}{l}\text { Conceitos } \\
\text { ocasionais }\end{array}$ & $\begin{array}{l}\text { Conceitos } \\
\text { constantes }\end{array}$ & \begin{tabular}{|l|} 
Conceitos \\
raros
\end{tabular} \\
\hline \multicolumn{4}{|c|}{ resultado para os alunos do período diurno } \\
\hline $\begin{array}{l}\text {-equação de K } \\
\text {-pressão } \\
\text {-quociente } \\
\text { reação (Q) } \\
\text {-reação favorável } \\
\end{array}$ & \begin{tabular}{|l|}
-variação de energia \\
livre $(\Delta \mathrm{G})$
\end{tabular} & $\begin{array}{l}\text {-extensão de reação } \\
\text {-rendimento de } \\
\text { reação } \\
\text {-reversibilidade }\end{array}$ & $\begin{array}{l}\text {-dinâmico } \\
\text {-íon comum } \\
\text {-equação química }\end{array}$ \\
\hline \multicolumn{4}{|c|}{ resultado para os alunos do período noturno } \\
\hline $\begin{array}{l}\text {-equação química } \\
\text {-variação de energia } \\
\text { livre }(\Delta G)\end{array}$ & \begin{tabular}{|l|}
-reversibilidade \\
-equação de K \\
-pressão \\
-quociente de \\
reação (Q) \\
\end{tabular} & $\begin{array}{l}\text {-dinâmico } \\
\text {-íon comum } \\
\text {-solubilidade } \\
\text {-reação favorável }\end{array}$ & $\begin{array}{l}\text {-extensão de reação } \\
\text {-rendimento de } \\
\text { reação }\end{array}$ \\
\hline \multicolumn{4}{|c|}{ comum aos dois grupos de alunos } \\
\hline $\begin{array}{l}\text {-concentração } \\
\text {-constante de } \\
\text { equilíbrio (K) } \\
\text {-deslocamento do } \\
\text { equilíbrio } \\
\text {-equilíbrio químico } \\
\text {-estado de equilíbrio } \\
\text {-princípio de Le } \\
\text { Chatelier } \\
\text {-produtos } \\
\text {-reação direta } \\
\text {-reação inversa } \\
\text {-reagentes } \\
\text {-temperatura } \\
\text {-velocidade de } \\
\text { reações }\end{array}$ & $\begin{array}{l}\text {-variação de } \\
\text { entalpia }(\Delta \mathrm{H})\end{array}$ & & $\begin{array}{l}\text {-ácido - base } \\
\text {-catalisador } \\
\text {-endotérmico } \\
\text {-estado estacionário } \\
\text {-exotérmico } \\
\text {-macroscópico } \\
\text {-microscópico } \\
\text {-potencial químico de } \\
\text {-produto } \\
\text { solubilidade } \\
\text {-variação de energia } \\
\text { livre padrão }\left(\Delta \mathrm{G}^{\circ}\right) \\
\text {-volume }\end{array}$ \\
\hline
\end{tabular}




\subsection{ESTUDO PILOTO: OBTENÇÃO DE UM MAPA CONCEITUAL REPRESENTATIVO DE CADA AMOSTRA ESTUDADA}

Ainda com o objetivo de comparar as duas amostras, integral e noturno, de alunos estudadas foi construído, a partir das matrizes finais, um mapa conceitual representativo para cada grupo (Figura 25 e Figura 26) O mapa obtido para o período diurno é mais elaborado contendo: (26 conceitos e 27 proposições) do que o do período noturno: (19 conceitos e 20 proposições) e apresenta relações entre conceitos termodinâmicos que não existem no mapa dos alunos do noturno. De uma maneira geral, estes resultados apontam para uma estrutura conceitual média dos alunos na qual a definição do equilíbrio químico está baseada na Lei da ação das massas e não na termodinâmica e a previsão de alterações do estado de equilíbrio químico é feita através da aplicação do Princípio de Le Chatelier e não da comparação entre quociente de reação e constante de equilíbrio.

Através dos mapas conceituais representativos ficam claras as diferenças entre os dois grupos estudados. Parte dos alunos do período integral faz relações envolvendo conceitos provenientes da Termodinâmica como: Constante de equilíbrio $K$ e Variação de energia livre $\Delta G^{\circ}(29 \%)$; Equilíbrio químico e Variação de energia $\Delta \mathrm{G}(26 \%)$; Constante de equilíbrio $K e$ quociente de reação $Q(29 \%)$ e Variação de energia $\Delta G$ e quociente de reação $Q(29 \%)$, muitas vezes utilizando as relações matemáticas que relacionam estes conceitos. O mesmo não ocorre com os alunos do período noturno que relacionam Equilíbrio químico diretamente ao Deslocamento do equilíbrio e ao Princípio de Le Chatelier.

Nos dois casos, acima descrito, observa-se a existência de relações fora do contexto do equilíbrio químico, por exemplo, aparecem com mais de $50 \%$ de incidência as relações entre Variação de Entalpia com Endotérmico e Exotérmico, ou ainda com Variação de energia livre de Gibbs (48\% nos mapas do período integral) ou Velocidade de reação com Catalisador (com mais de $40 \%$ nos dois grupos). Isto indica que antes de pensar nos possíveis papéis 
destes conceitos para o tema em questão os alunos tendem a fazer as relações mais óbvias e conhecidas.

Este fato caracteriza uma limitação do método, que não é capaz de verificar se realmente não existem, na estrutura conceitual dos alunos, relações entre estes conceitos que sejam importantes para o tema em estudo, como por exemplo, o fato de que um Catalisador não alterar o Estado de equilíbrio, ou o uso do sinal de $\Delta H$ para a previsão da alteração de um Estado de equilíbrio com variações de Temperatura (esta relação apareceu em boa parte dos mapas dos alunos do período noturno). Estas observações parecem indicar que para verificar a capacidade ou não dos alunos em estabelecer estas relações através de mapas conceituais é preciso mudar a metodologia, partindo para uma lista de conceitos menos ampla, para perguntas focais mais específicas ou para outras abordagens de aplicação de mapas conceituais mais dirigidas como os métodos que prevêem que os alunos preencham espaços em branco em um mapa conceitual dado, referente ao conceito ou à frase de ligação (Ruiz-Primo, 2004).

Os mapas representativos (Figura 25 e Figura 26) também mostram erros conceituais importantes como os expressos por alunos que firmam que 0 Princípio de Le Chatelier explica, causa, governa ou proporciona o Deslocamento do equilíbrio; ou ainda a proposição que afirma que o Equilíbrio químico é regido/ obedece, é baseado ou é alterado pelo Princípio de Le Chatelier. Essas proposições são apresentadas por 36\% dos alunos. 


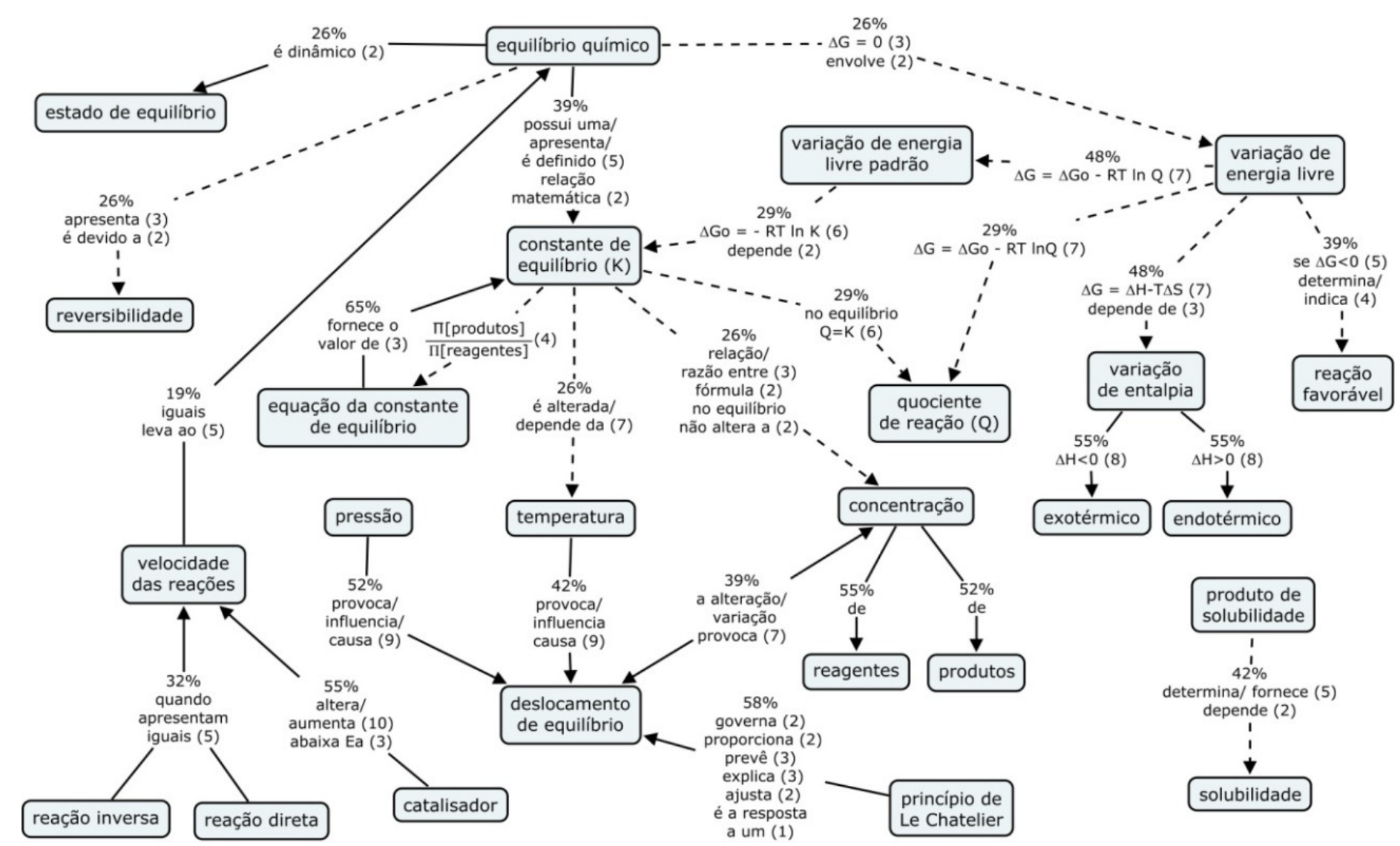

Figura 25- Mapa conceitual representativo para o grupo de alunos do curso integral. As linhas tracejadas representam as relações que são exclusivas desse mapa. Os valores percentuais representam a proporção de alunos que ligou os dois conceitos. Entre parênteses está o número de ocorrências da frase de ligação. 


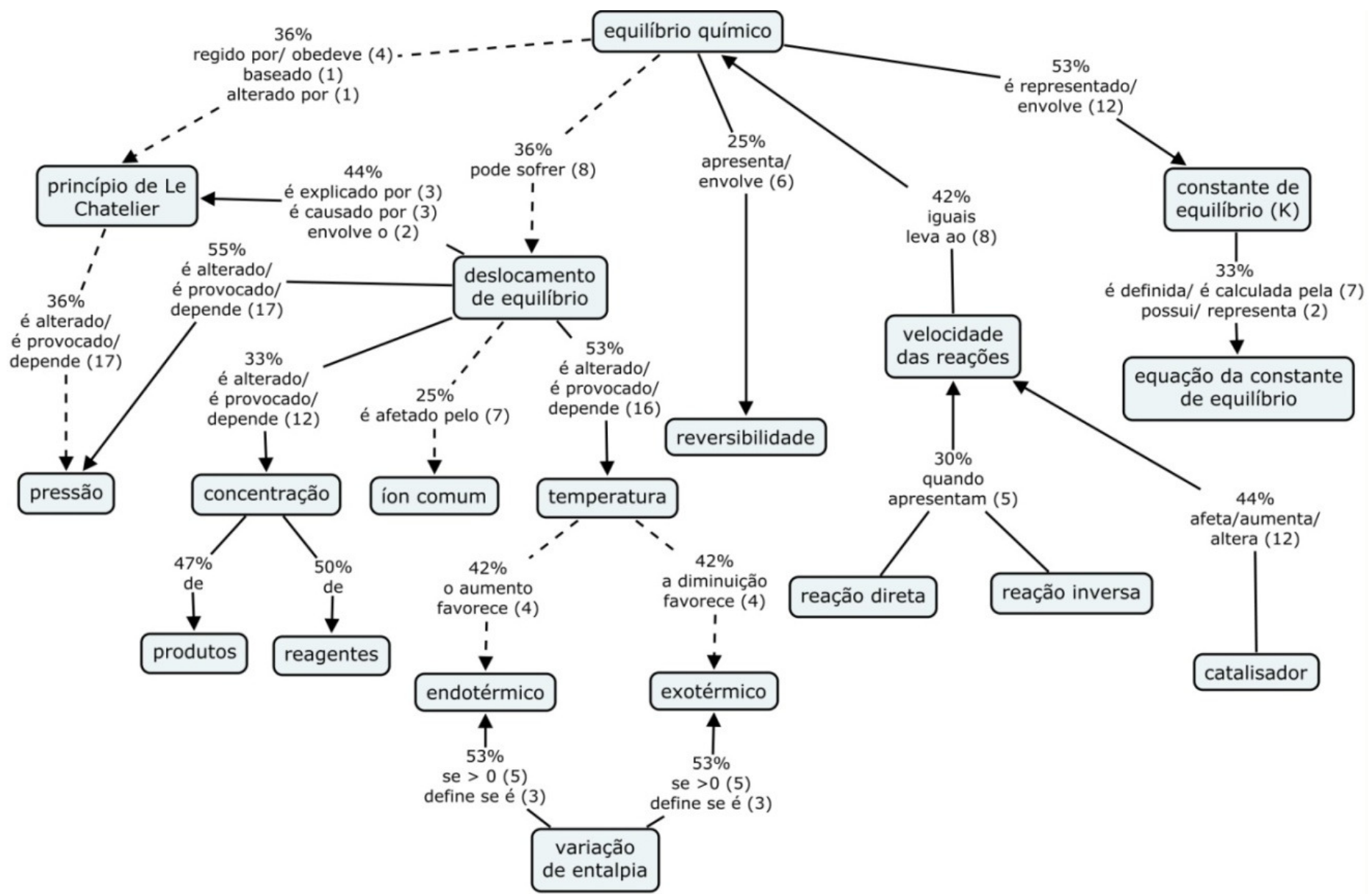

Figura 26- Mapa conceitual representativo para o grupo de alunos do curso noturno. As linhas tracejadas representam as relações que são exclusivas desse mapa. Os valores percentuais representam a proporção de alunos que ligou os dois conceitos. Entre parênteses está o número de ocorrências da frase de ligação. 


\subsection{ESTUDO DAS ALTERAÇÕES DA ESTRUTURA CONCEITUAL SOBRE O TEMA EQUILÍBRIO QUÍMICO EM ALUNOS INGRESSANTES NO CURSO DE QUÍMICA}

\subsubsection{ANÁLISE GERAL DOS MAPAS CONCEITUAIS}

Ao todo 49 alunos do primeiro ano do curso de graduação em química do período noturno matriculados na disciplina "Introdução às Transformações Químicas”, confeccionaram mapas conceituais sobre o tema equilíbrio químico, porém, serão analisados somente os mapas dos dezessete alunos que também o fizeram durante a disciplina de Química Inorgânica, no final do ano letivo de 2008. Os mapas conceituais produzidos pelos alunos em folha de papel foram reconstruídos com o software cmap tools para melhor visualização. Nesse processo, procurou-se ser fiel à estrutura do mapa original, tanto quanto à sua organização espacial quanto à escrita dos conceitos e das frases de ligação. Observam-se pelas Figuras 27 a 32 apresentadas a título de ilustração e comparação, mapas elaborados por esses alunos em maio de 2008.

Dos 17 mapas, doze (70\%) apresentam como conceito mais inclusivo Equilíbrio Químico e quatro (23\%) apresentam a hierarquia central com o conceito Reação Química; o que nos demonstra uma hegemonia de critérios por parte dos alunos, podendo assim ser reagrupados por critérios semelhantes de estrutura cognitiva. $\mathrm{O}$ fato de $70 \%$ dos alunos escolherem o conceito Equilíbrio Químico está relacionado com as instruções dadas a estes alunos que sugeriria a construção do mapa a partir deste conceito (ANEXO 1). No entanto, um número expressivo $23 \%$ dos alunos elencaram Reação Química como conceito mais inclusivo que o próprio Equilíbrio Químico. Ressalta-se ainda que nas instruções para a construção do mapa foi solicitado que organizassem os conceitos de maneira hierárquica antes mesmo da construção do mapa e que no momento desta coleta de dados os alunos não haviam sido submetidos ao estudo do tópico equilíbrio químico. 


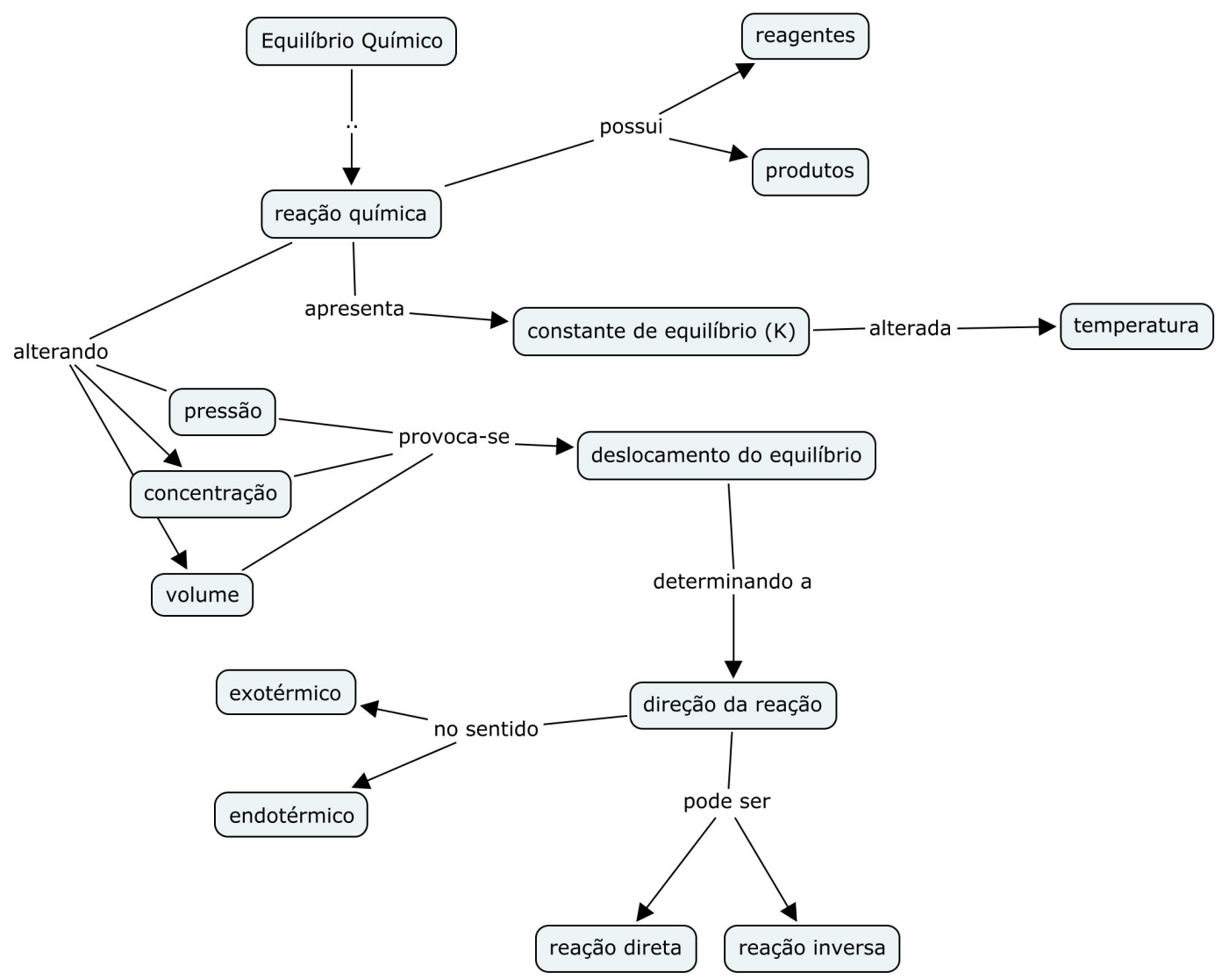

Figura 27-Mapa aluno-1 1 ano 2008- Ingressante. 


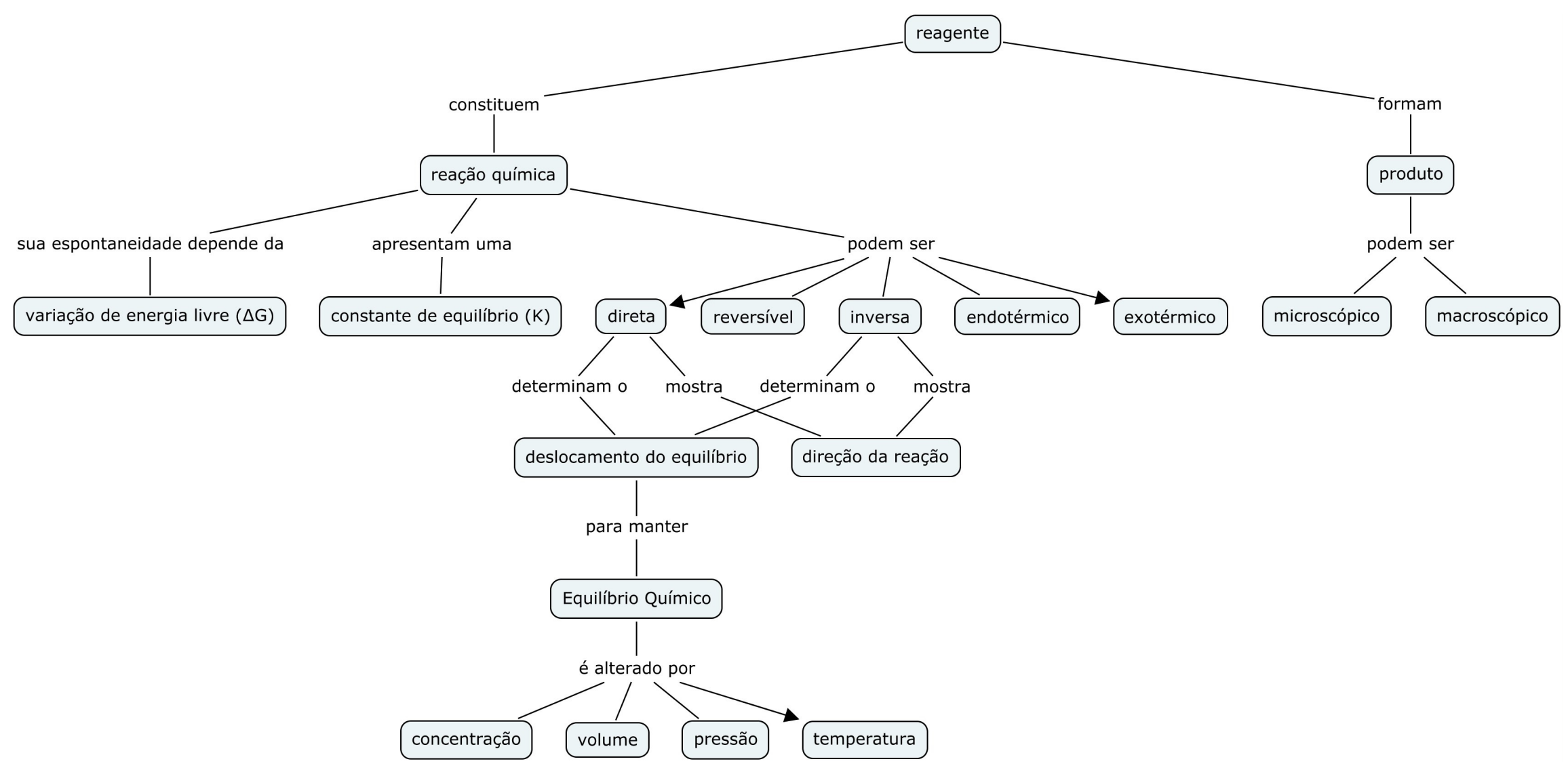

Figura 28-Mapa aluno-1 1ํano 2008-Após um ano de Curso-Inorgânica. 


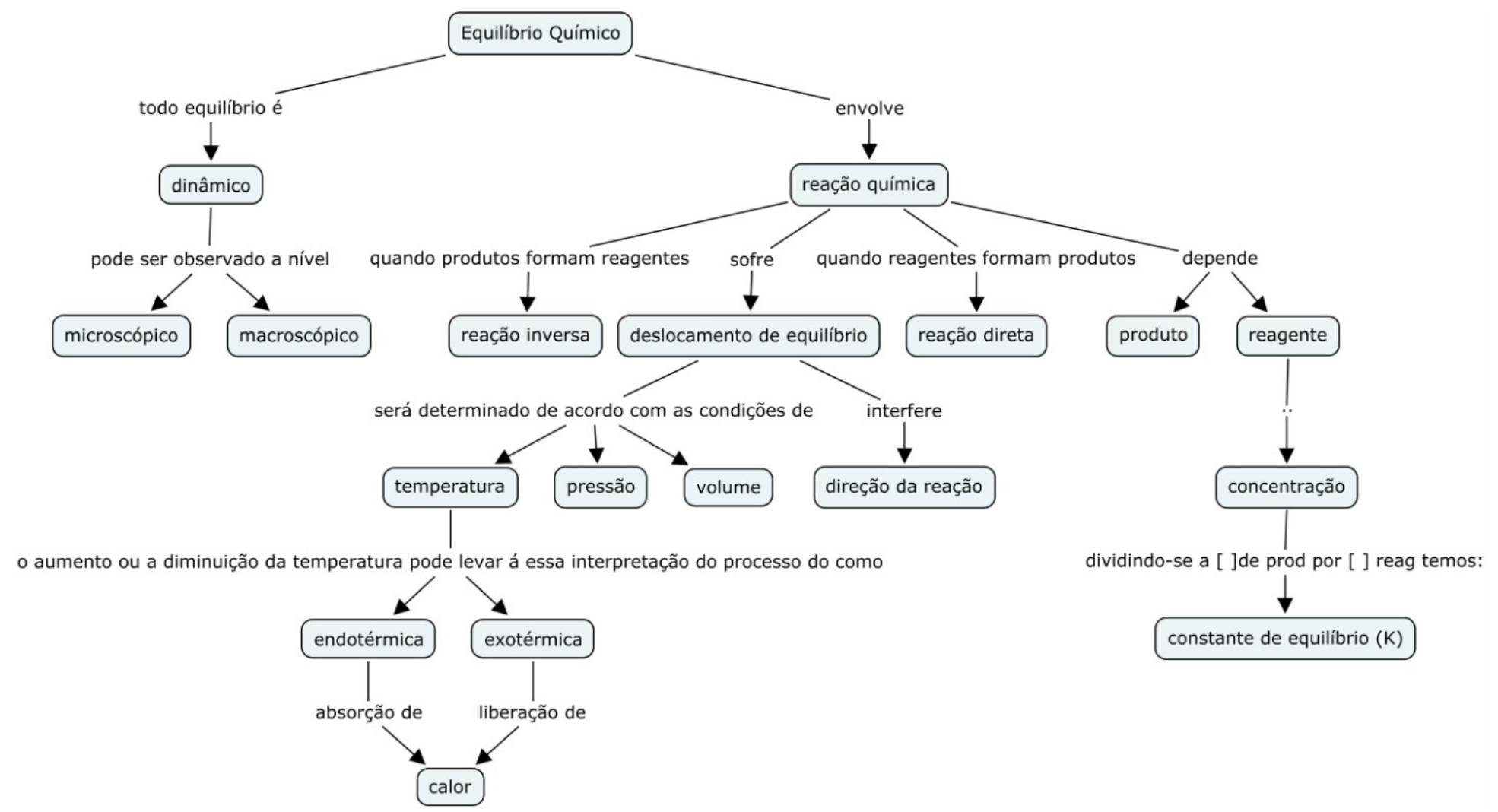

Figura 29-Mapa aluno-47 10 ano 2008-Ingressante. 


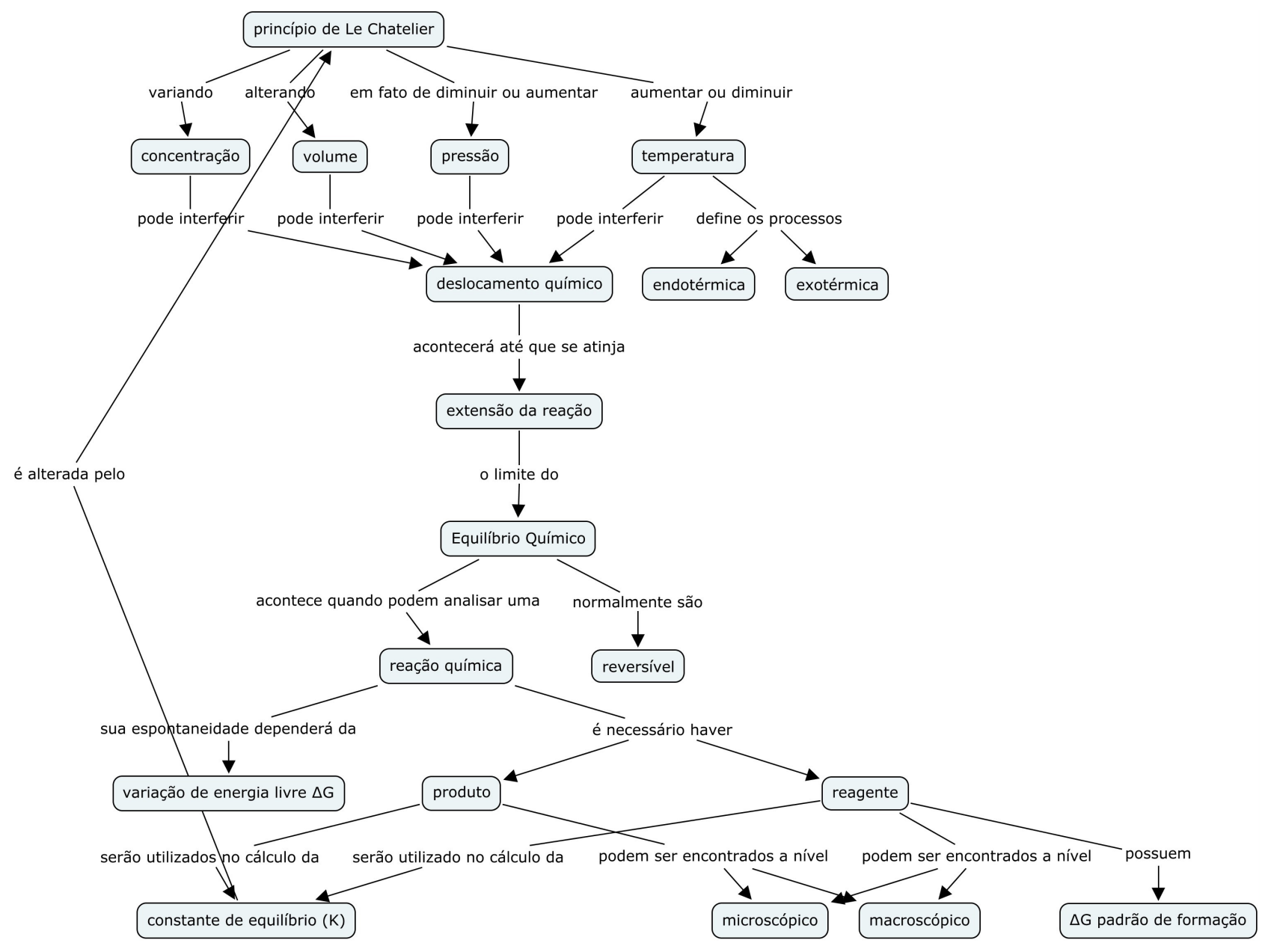

Figura 30-Mapa aluno-47 10 ano 2008-após um ano de curso. 


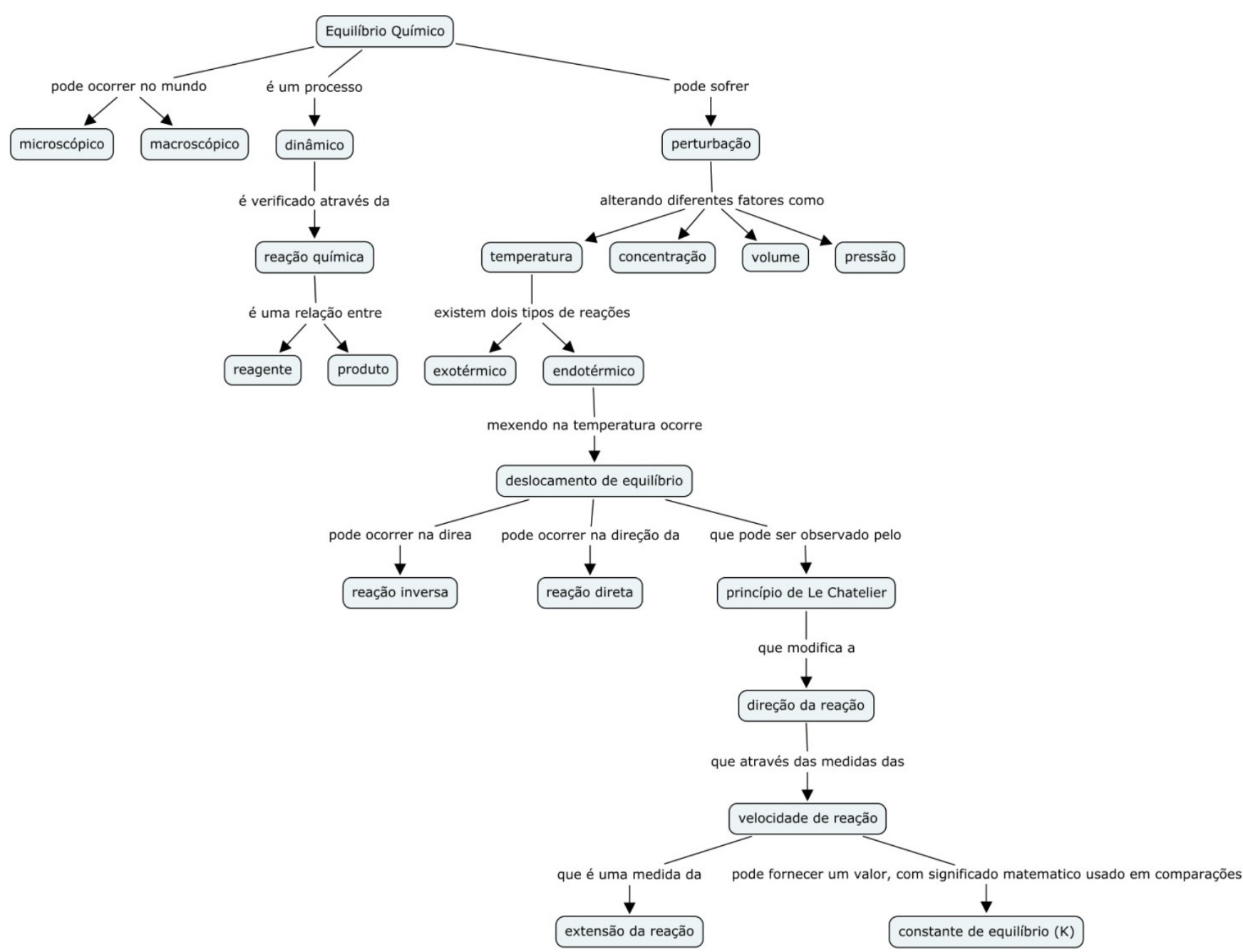

Figura 31- Mapa aluno-36 10 ano 2008-Ingressante 


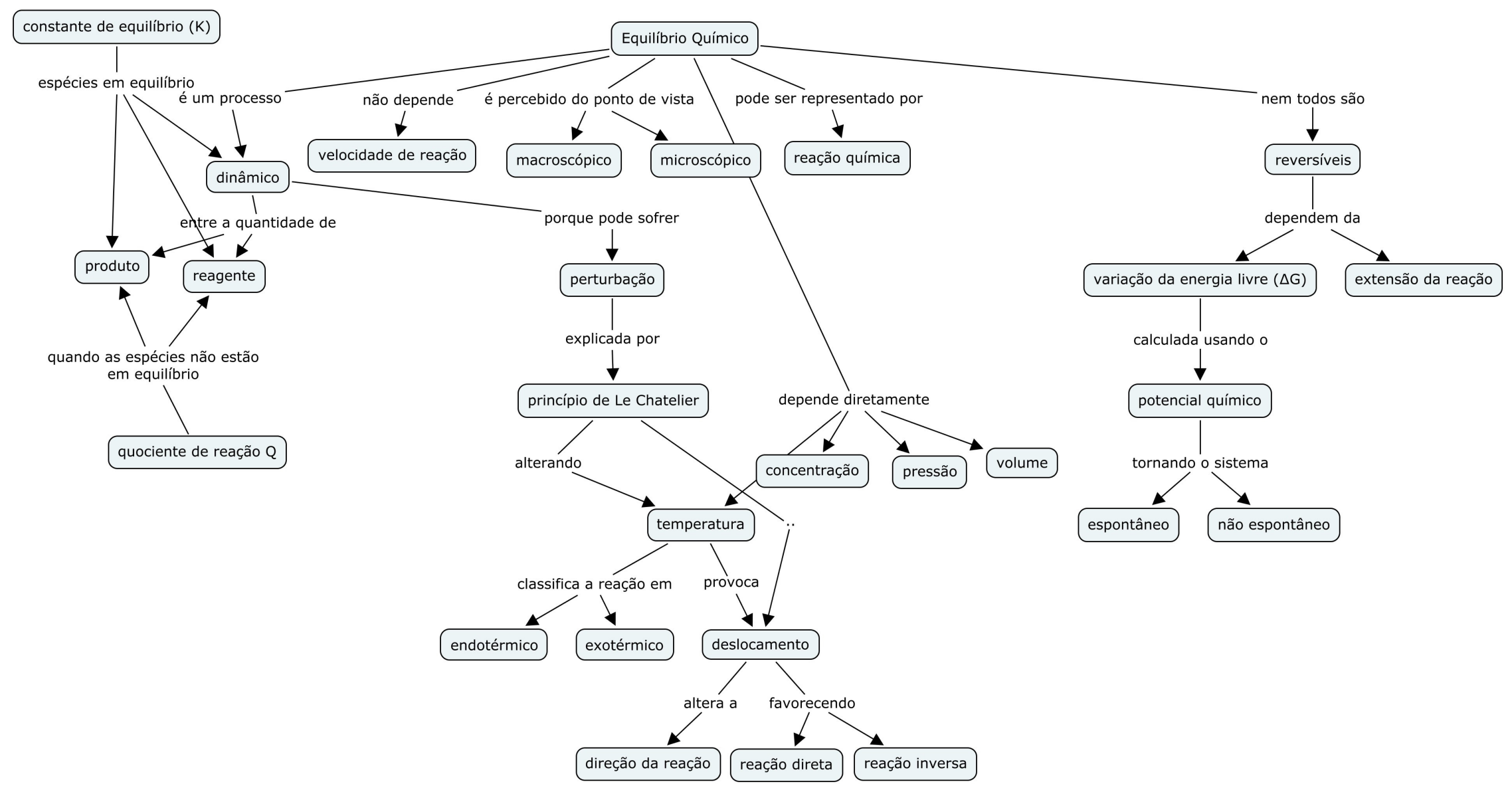

Figura 32- Mapa aluno-36 10 ano 2008-após um ano de curso. 
De todos os mapas construídos pelos alunos, apenas um apresenta como conceito mais hierárquico Princípio de Le Chatelier, este conceito está relacionado a compreensão da mudança do estado de equilíbrio, os alunos apresentam tal dificuldade por se tratar de um conceito mais específico e para relacioná-lo o aluno deve possuir uma compreensão que vá além de simplesmente memorizar o princípio como uma regra.

Ao final do ano letivo, após estudarem o tema equilíbrio químico, os mapas conceituais elaborados pelos alunos apresentaram uma pequena mudança na ocorrência do conceito de maior hierarquia. Dos 17 alunos estudados, dez (58\%) apresentam como conceito mais inclusivo Equilíbrio Químico e cinco (29\%) apresentam a hierarquia central com o conceito Reação Química, um (5\%) apresenta o conceito Princípio de Le Chatelier e um (5\%) o conceito Velocidade das Reações como conceito mais hierárquico. A mudança de nível de hierarquia dos conceitos nos demonstra que os alunos apresentam uma alteração em seu entendimento sobre o tópico equilíbrio químico. Um exemplo de mapa conceitual construído em novembro de 2008, após o estudo do tema é apresentado na Figura 28, Figura 30 e Figura 32 a título de ilustração e comparação.

Após um ano de curso, verificando os mapas construídos pelos alunos nota-se as mudanças ocorridas em termos de número de conceitos Figura 33. Percebe-se um aumento no número de conceitos elencados nos mapas construídos pelos alunos, em média 2 conceitos a mais comparados aos mapas construídos no início do curso, ingressantes, além do aumento do numero de conceitos verifica-se que estes denotam uma compreensão mais completa do tema, como por exemplo, conceitos como variação de energia livre, princípio de Le Chatelier, extensão da reação; os quais não foram verificados nos mapas construídos pelos alunos ingressantes.

O número de conceitos utilizados nos mapas após um ano de curso apresentam um aumento considerável (cerca de $88 \%$ dos mapas) quando comparado aos desenvolvidos quando os alunos eram ingressantes, disciplina Introdução as transformações químicas, além da mudança hierárquica de alguns conceitos. 


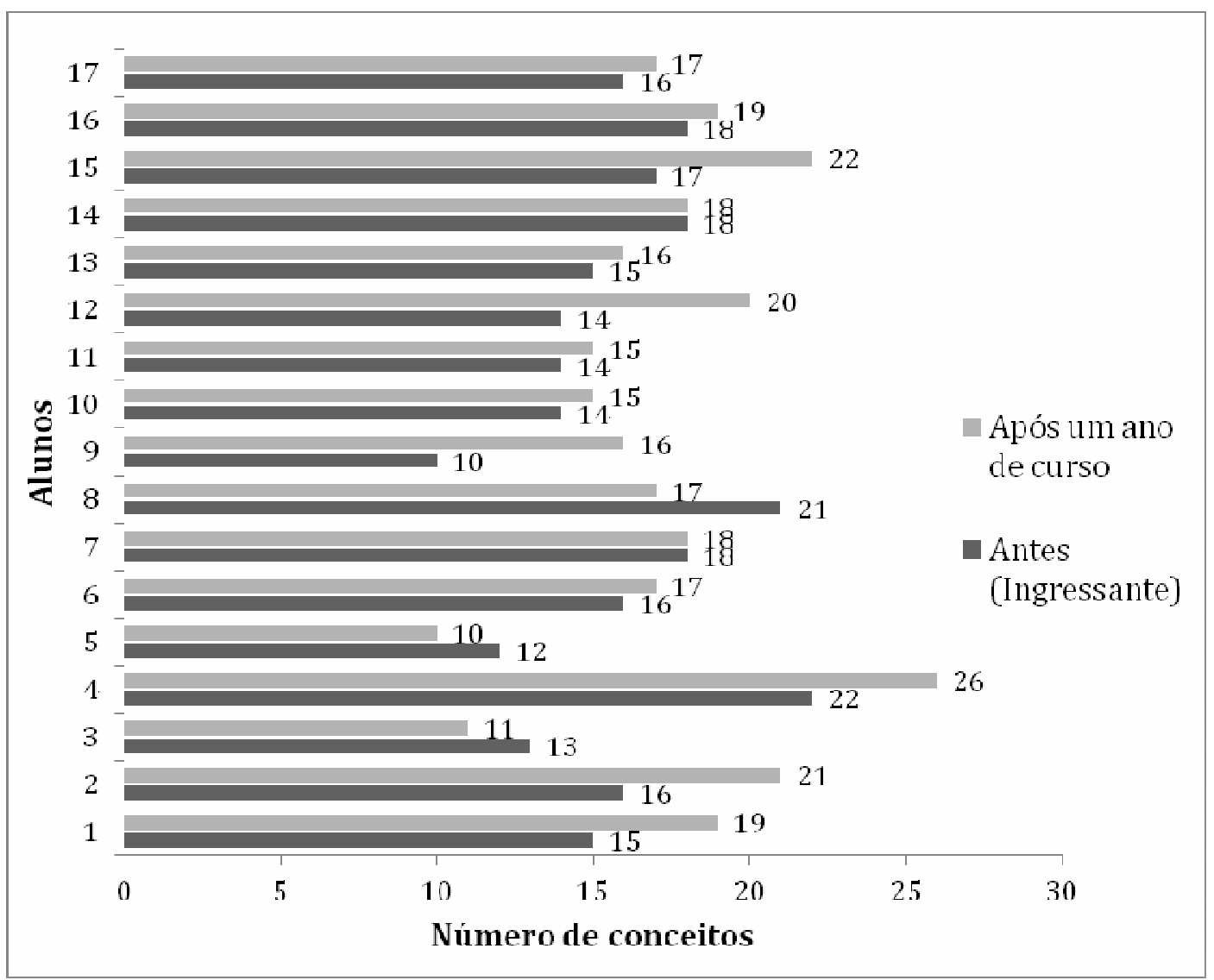

Figura 33- Número de conceitos presentes em cada mapa conceitual.

(Alunos ingressantes e após um ano de curso)

A comparação entre os mapas feitos por um mesmo aluno permite verificar diferenças interessantes entre os mesmos que refletem um melhor aprendizado pelo aluno. Por exemplo, no caso do aluno 1, o conceito Equilíbrio Químico considerado pelo mesmo como mais inclusivo em seu primeiro mapa passou a ter outro nível hierárquico, sendo que no segundo mapa o termo mais inclusivo passou a ser reação química. No segundo mapa aparecem ainda quatro novos conceitos: microscópico, macroscópico, reversível e variação de energia livre. O mapa apresenta frases de ligação com maior complexidade, além de outras que não apareciam, como por exemplo:

Reação química $\rightarrow$ sua espontaneidade depende da $\rightarrow$ variação de energia livre $(\Delta G)$

Equilíbrio químico $\rightarrow$ é alterado por $\rightarrow$ concentração 
No caso do segundo mapa construído pelo aluno 47, Figura 30 o conceito eleito pelo aluno de maior nível hierárquico foi o Princípio de Le Chatelier e o conceito Equilíbrio químico o qual no primeiro momento era o mais incluso passou a ser de nível inferior. $O$ aluno também relacionou outros quatro novos conceitos: extensão da reação, princípio de Le Chatelier, reversível e variação de energia livre ( $\Delta G)$.

As proposições estabelecidas pelo aluno na primeira construção dos mapas demonstram relações matemáticas memorísticas, muito características das encontradas em livros de ensino médio, conforme demonstrado nas Figura 34 e Figura 35.

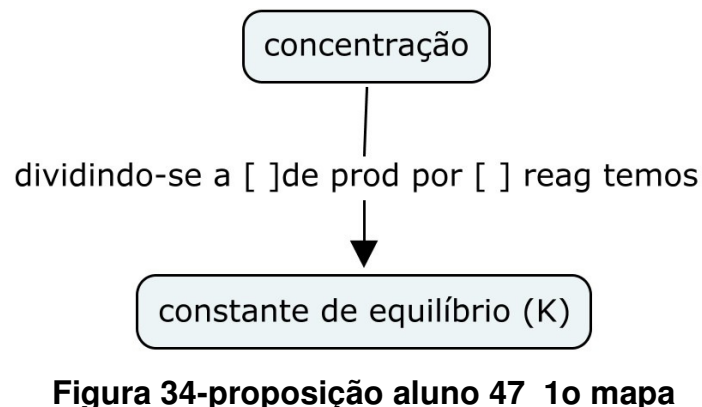

Figura 34-proposição aluno 47_10 mapa

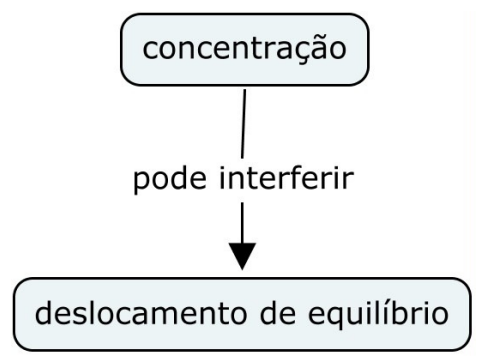

Figura 35-proposição aluno 47_2o mapa

Muito recorrente, verifica-se um destaque para a definição de Constante de Equílibrio em função das concentrações, de maneira algorítimica, muito encontrado em livros didáticos do nível médio.

Constante de equilíbrio em função das concentrações, e em destaque:

$$
R c=\frac{[C]^{e}}{[A]^{\alpha}[B]^{b}}
$$

Já os conceitos: Potencial Químico, Variação de Energia livre e Variação de energia livre padrão, não existe nenhuma menção em livros mais utilizados no ensino de química para o ensino médio. Estes conceitos não foram relacionados em nenhum mapa construído pelos alunos ingressantes.

Verificando a organização hierárquica dos mapas conceituais construídos pelo aluno 36, Figura 31 Figura 32, observa-se que não houve mudança em termos hierárquicos, ou seja, o conceito Equilíbrio químico foi 
eleito como de maior nível hierárquico no $1^{\circ}$ mapa e no $2^{\circ}$ mapa este permaneceu neste mesmo nível. Porém o número de conceitos relacionados pelo aluno na construção de seu mapa aumentou: extensão da reação, potencial químico, reversível e variação de energia livre $(\Delta G)$. As proposições também foram modificadas, em seu $1^{\circ}$ mapa verificam-se proposições quase algorítmicas e outras erradas.

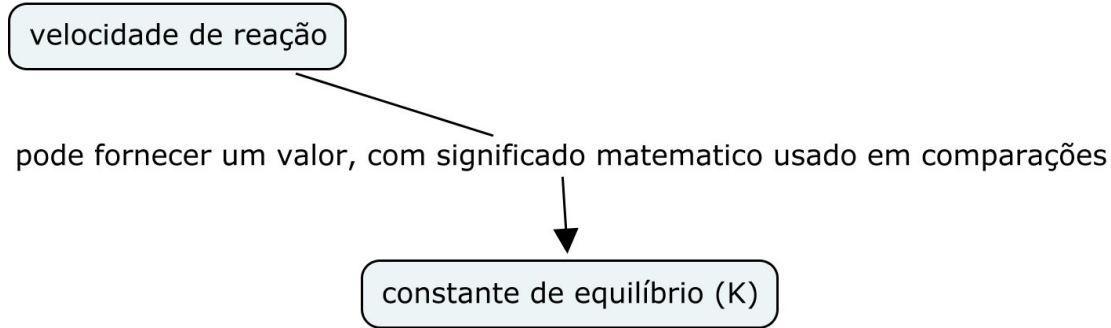

Figura 36-proposição aluno 36_10 mapa

princípio de Le Chatelier

que modifica a

$$
\text { direção da reação }
$$

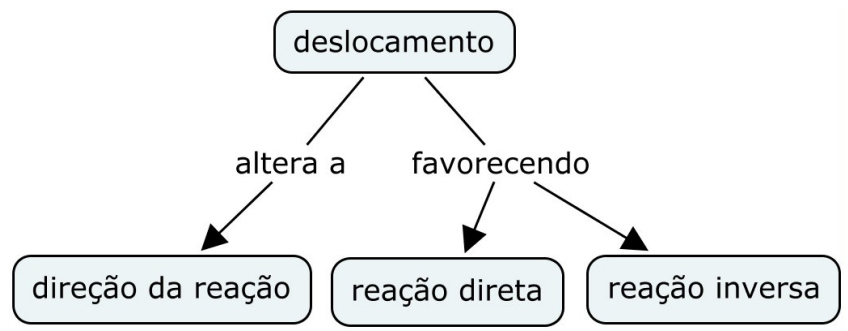

Figura 38-proposição aluno 36_2o mapa

Figura 37-proposição aluno 36_10 mapa 


\subsubsection{APLICAÇÃO NA NOVA PROPOSTA DE ANÁLISE}

Os mapas construídos pelos alunos ingressantes-2008 foram transformados em Matrizes, como ilustrados na Figura 8. A somatória de todas as matrizes deu origem a Matriz final ilustrada na Figura 39 pela qual se obteve:

a) Número total de relações para cada conceito $(\mathrm{R})$;

b) Número total de relações por mapa (R/M);

c) Número total da freqüência de relações para cada conceito $(F)$ e

d) Total da freqüência de relações em \%, para cada conceito (\%F).

Como critério de análise adotou-se as relações com um valor igual ou acima de 5 para serem verificadas, ou seja, as quais correspondem a pelo menos $29 \%$ do total dos mapas elaborados, conforme descrito em nossa metodologia de trabalho. Na Tabela 4 são apresentados os resultados obtidos utilizando a AEMC-Adaptada para os mapas conceituais elaborados pelos alunos ingressantes, em maio de 2008. Para melhor visualização foi aplicado a Prova de Associação de Olmstead-Tokey (González-Yoval, 2004), obtendo assim um gráfico (Figura 40) o qual relaciona o número de relações e a freqüência de associações.

Os conceitos dominantes determinados nos mapas estão relacionados às condições e à reação química, deslocamento e a definição do estado de equilíbrio químico. O conceito Velocidade das reações classificado como dominante apresenta trinta e seis relações nos dezessete mapas com uma porcentagem de freqüência de $55 \%$, ou seja, oito alunos relacionaram pelo menos uma vez o conceito, sendo que desses, quatro fizeram mais de uma relação para o mesmo conceito. 


\begin{tabular}{|c|c|c|c|c|c|c|c|c|c|c|c|c|c|c|c|c|c|c|c|c|c|c|c|c|c|c|c|c|c|c|c|c|c|}
\hline & & 1 & 2 & 3 & 4 & 5 & 6 & 7 & 8 & & 10 & 11 & 12 & 13 & 14 & 15 & 16 & 1 & 18 & 19 & 20 & 21 & 22 & 23 & 24 & 25 & 26 & 27 & 28 & & & & \\
\hline concentração & 1 & & 4 & 6 & 0 & 1 & 0 & 3 & 0 & 1 & 0 & 0 & 0 & 1 & 0 & 0 & 3 & 6 & 0 & 0 & 0 & 2 & 8 & 0 & 0 & 0 & 0 & 3 & 1 & 39 & 2,3 & 12 & 70,6 \\
\hline constante de equilibrio (K) & 2 & 4 & & 2 & 0 & 0 & 0 & 4 & 0 & 0 & 0 & 0 & 0 & 1 & 0 & 3 & 2 & 4 & 0 & 0 & 0 & 3 & 4 & 0 & 5 & 0 & 0 & 5 & 1 & 38 & 2,2 & 12 & 44,4 \\
\hline deslocamento de equilibrio & 3 & 6 & 2 & & 0 & 4 & 2 & 3 & 1 & 0 & 0 & 0 & 0 & 1 & 0 & 8 & 5 & 1 & 0 & 3 & 2 & 1 & 1 & 0 & 7 & 0 & 0 & 2 & 3 & 52 & $\overline{3,1}$ & 17 & 63 \\
\hline dinâmico & 4 & 0 & 0 & 0 & & 0 & 0 & 6 & 0 & 0 & 0 & 1 & 1 & 0 & 0 & 0 & 1 & 0 & 0 & 1 & 1 & 2 & 0 & 0 & 0 & 0 & 0 & 0 & 0 & 13 & $\overline{0,8}$ & 7 & 25,9 \\
\hline direção da reação & 5 & 1 & 0 & 4 & 0 & & 2 & 1 & 2 & 0 & 0 & 0 & 0 & 1 & 0 & 3 & 1 & 2 & 1 & 7 & 7 & 1 & 3 & 0 & 4 & 0 & 0 & 1 & 3 & 44 & 2,6 & 17 & 63 \\
\hline endotérmico & 6 & 0 & 0 & 2 & 0 & 2 & & 0 & 0 & 0 & 0 & 0 & 0 & 0 & 0 & 0 & 0 & 1 & 0 & 0 & 0 & 4 & 1 & 0 & 8 & 0 & 0 & 0 & 0 & 18 & $\overline{1,1}$ & 6 & 22,2 \\
\hline equilibrio químico & 7 & 3 & 4 & 3 & 6 & 1 & 0 & & 0 & 0 & 0 & 1 & 1 & 4 & 0 & 4 & 1 & 1 & 0 & 0 & 0 & 8 & 2 & 2 & 4 & 0 & 0 & 3 & 3 & 51 & 3 & 17 & 63 \\
\hline exotérmico & 8 & 0 & 0 & 1 & 0 & 2 & 0 & 0 & & 0 & 0 & 0 & 0 & 0 & 0 & 0 & 0 & 1 & 0 & 0 & 1 & 3 & 1 & 0 & 8 & 0 & 0 & 0 & 0 & 17 & 1 & 7 & 25,9 \\
\hline extensão de reação & 9 & 0 & 0 & 0 & 0 & 0 & 0 & 0 & 0 & & 0 & 0 & 0 & 0 & 0 & 0 & 0 & 0 & 0 & 0 & 0 & 0 & 0 & 0 & 0 & 0 & 0 & 2 & 0 & 2 & $\overline{0,1}$ & 1 & 3,7 \\
\hline lei de ação das massas & 10 & 0 & 0 & 0 & 0 & 0 & 0 & 0 & 0 & 0 & & 0 & 0 & 0 & 0 & 0 & 0 & 0 & 1 & 0 & 0 & 0 & 0 & 0 & 0 & 0 & 0 & 1 & 0 & 2 & $\overline{0,1}$ & 2 & 7,41 \\
\hline macroscópico & 11 & 0 & 0 & 0 & 1 & 0 & 0 & 1 & 0 & 0 & 0 & & 0 & 1 & 0 & 0 & 0 & 0 & 0 & 0 & 0 & 3 & 0 & 0 & 1 & 0 & 0 & 0 & 0 & 7 & $\overline{0,4}$ & 5 & 18,5 \\
\hline microscópico & 12 & 0 & 0 & 0 & 1 & 0 & 0 & 1 & 0 & 0 & 0 & 0 & & 1 & 0 & 0 & 0 & 0 & 0 & 0 & 0 & 3 & 0 & 1 & 0 & 0 & 0 & 0 & 0 & 7 & $\overline{0,4}$ & 5 & 18,5 \\
\hline perturbação & 13 & 1 & 1 & 1 & 0 & 1 & 0 & 4 & 0 & 0 & 0 & 1 & 1 & & 0 & 1 & 1 & 0 & 0 & 0 & 0 & 0 & 0 & 0 & 1 & 0 & 0 & 1 & 1 & 15 & $\overline{0,9}$ & 12 & 44,4 \\
\hline potencial químico & 14 & 0 & 0 & 0 & 0 & 0 & 0 & 0 & 0 & 0 & 0 & 0 & 0 & 0 & & 0 & 0 & 0 & 0 & 0 & 0 & 0 & 0 & 0 & 0 & 0 & 0 & 0 & 0 & 0 & \begin{tabular}{|l}
0 \\
\end{tabular} & 0 & 0 \\
\hline pressão & 15 & 0 & 3 & 8 & 0 & 3 & 0 & 4 & 0 & 0 & 0 & 0 & 0 & 1 & 0 & & 2 & 0 & 0 & 0 & 0 & 2 & 0 & 0 & 0 & 0 & 0 & 4 & 1 & 28 & $\overline{1,6}$ & 9 & 33,3 \\
\hline princípio de Le Chatelier & 16 & 3 & 2 & 5 & 1 & 1 & 0 & 1 & 0 & 0 & 0 & 0 & 0 & 1 & 0 & 2 & & 0 & 0 & 0 & 0 & 0 & 0 & 1 & 0 & 0 & 0 & 1 & 1 & 19 & $\overline{1,1}$ & 11 & 40,7 \\
\hline produtos & 17 & 6 & 4 & 1 & 0 & 2 & 1 & 1 & 1 & 0 & 0 & 0 & 0 & 0 & 0 & 0 & 0 & & 1 & 4 & 3 & 8 & 1 & 1 & 0 & 0 & 0 & 0 & 0 & 34 & 2 & 13 & 48,1 \\
\hline quociente de reação $(\mathrm{Q})$ & 18 & 0 & 0 & 0 & 0 & 1 & 0 & 0 & 0 & 0 & 1 & 0 & 0 & 0 & 0 & 0 & 0 & 1 & & 0 & 0 & 0 & 0 & 0 & 0 & 0 & 0 & 0 & 0 & 3 & 0,2 & 3 & 11,1 \\
\hline reação direta & 19 & 0 & 0 & 3 & 2 & 7 & 0 & 0 & 0 & 0 & 0 & 0 & 0 & 0 & 0 & 0 & 0 & 4 & 0 & & 0 & 4 & 0 & 3 & 0 & 0 & 0 & 2 & 0 & 25 & 1,5 & 7 & 25,9 \\
\hline reação inversa & 20 & 0 & 0 & 2 & 2 & 7 & 0 & 0 & 1 & 0 & 0 & 0 & 0 & 0 & 0 & 0 & 0 & 3 & 0 & 0 & & 4 & 4 & 3 & 1 & 0 & 0 & 2 & 0 & 29 & 1,7 & 10 & 37 \\
\hline reação química & 21 & 2 & 3 & 1 & 2 & 1 & 4 & 8 & 3 & 0 & 0 & 3 & 3 & 0 & 0 & 2 & 0 & 8 & 0 & 4 & 4 & & 7 & 3 & 0 & 0 & 0 & 3 & 2 & 63 & \begin{tabular}{|l}
3,7 \\
\end{tabular} & 18 & 66,7 \\
\hline reagentes & 22 & 8 & 4 & 1 & 0 & 3 & 1 & 2 & 1 & 0 & 0 & 0 & 0 & 0 & 0 & 0 & 0 & 1 & 0 & 1 & 4 & 7 & & 0 & 0 & 0 & 0 & 0 & 0 & 33 & 1,9 & 11 & 40,7 \\
\hline reversivel & 23 & 0 & 0 & 0 & 0 & 0 & 0 & 2 & 0 & 0 & 0 & 0 & 1 & 0 & 0 & 0 & 1 & 0 & 0 & 3 & 3 & 3 & 0 & & 0 & 0 & 0 & 0 & 0 & 13 & 0,8 & 6 & 22,2 \\
\hline temperatura & 24 & 0 & 5 & 7 & 0 & 4 & 8 & 4 & 8 & 0 & 0 & 1 & 0 & 1 & 0 & 0 & 0 & 0 & 0 & 0 & 0 & 1 & 0 & 0 & & 0 & 0 & 4 & 0 & 43 & \begin{tabular}{|l|}
2,5 \\
\end{tabular} & 10 & 37 \\
\hline variação de energia livre $(\Delta G)$ & 25 & 0 & 0 & 0 & 0 & 0 & 0 & 0 & 0 & 0 & 0 & 0 & 0 & 0 & 0 & 0 & 0 & 0 & 0 & 0 & 0 & 0 & 0 & 0 & 0 & & 0 & 0 & 0 & 0 & 0 & 0 & 0 \\
\hline variação de energia livre padrão ( $\Delta \mathrm{Go})$ & 26 & 0 & 0 & 0 & 0 & 0 & 0 & 0 & 0 & 0 & 0 & 0 & 0 & 0 & 0 & 0 & 0 & 0 & 0 & 0 & 0 & 0 & 0 & 0 & 0 & 0 & & 0 & 0 & 0 & 0 & 0 & 0 \\
\hline velocidade de reações & 27 & 3 & 5 & 2 & 0 & 1 & 0 & 2 & 0 & 2 & 1 & 0 & 0 & 1 & 0 & 4 & 1 & 0 & 0 & 2 & 2 & 3 & 0 & 0 & 4 & 0 & 0 & & & 36 & $\overline{2,1}$ & 15 & 55,6 \\
\hline volume & 28 & 1 & 1 & 3 & 0 & 3 & 0 & 3 & 0 & 0 & 0 & 0 & 0 & 1 & 0 & 1 & 1 & 0 & 0 & 0 & 0 & 2 & 0 & 0 & 0 & 0 & 0 & 3 & & 19 & 1,1 & 10 & 37 \\
\hline
\end{tabular}

Figura 39-Matriz final obtida para o grupo de alunos referente a disciplina Q.Transformações. Em destaque estão as relações com frequência maior ou igual a $5(29 \%$ da amostra estudada). 


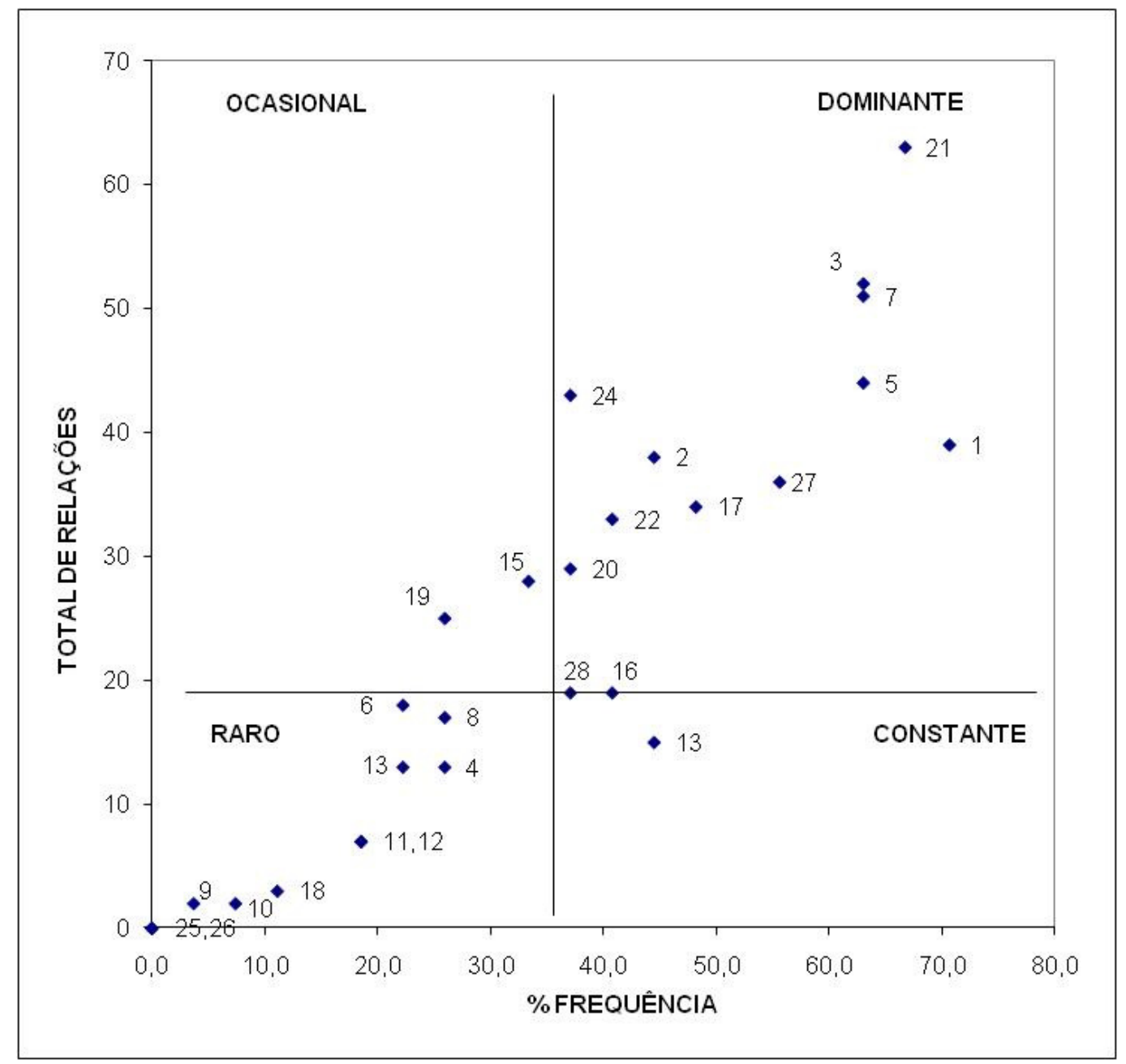

Figura 40-Gráfico obtido a partir da AEMC para os alunos ingressantes do $1^{\circ}$ ano de 2008. Prova de Associação de Olmstead-Tukey para a matriz soma dos mapas conceituais elaborados pelos alunos referente a disciplina Q.Transformações. Cada ponto corresponde a um conceito: 1-concentração, 2-constante de equilíbrio (K), 3-deslocamento de equilíbrio, 4dinâmico, 5-direção da reação, 6-endotérmico, 7-equilíbrio químico, 8-exotérmico, 9-extensão da reação, 10-lei de ação das massas, 11-macroscópico, 12-microscópico, 13-perturbação, 14potencial químico, 15-pressão, 16-princípio de Le Chatelier, 17-produtos, 18-quociente de reação $(Q)$, 19-reação direta, 20-reação inversa, 21-reação química, 22-reagentes, 23reversível, 24-temperatura, 25-variação de energia livre $(\Delta \mathrm{G})$, 26-variação de energia livre padrão $\left(\Delta G^{\circ}\right)$, 27-velocidade de reações, 28-volume. 
Podemos entender este fato por o tópico equilíbrio químico ser abordado no ensino médio, com base na lei de ação das massas. De maneira pouco clara os livros didáticos não abordam o tema equilíbrio químico como fenômeno dinâmico, comumente, é introduzido através das velocidades e concentrações, assumindo que, quando as velocidades das reações de formação de produtos e de formação de reagentes (reações direta e inversa, respectivamente) se igualam e, portanto, as concentrações das espécies envolvidas se mantém constantes. Na grande maioria dos livros didáticos o tema Equilíbrio Químico é apresentado sequencialmente após o tema Cinética Química, onde destacam que:

"No Equilíbrio químico $V 1=V 2 \Rightarrow \frac{k_{1}}{k_{2}}=K C=\frac{[\mathrm{prod}]}{[\operatorname{reg}]}$ Constante de equilíbrio em função das concentrações"

$$
\begin{gathered}
\mathrm{Kc}=\mathrm{Vd} / \mathrm{Vi} \\
\mathrm{Kc}=\frac{[C]^{e}}{[A]^{\alpha}[B]^{b}}
\end{gathered}
$$

As proposições apresentadas caracterizam fortemente a relação estabelecida entre o equilíbrio químico e velocidade de reações e ou Constante de equilíbrio depende da velocidade, aspectos enfatizados na abordagem com os alunos; proposições apresentadas pelos alunos 7 e 48 :

Equilíbrio químico $\rightarrow$ ocorre quando se igualam $\rightarrow$ velocidade da reação

Velocidade da reação $\rightarrow$ depende $\rightarrow$ constante de equilíbrio

Observa-se pela análise bidimensional (Figura 40 e Tabela 4) que, entre os conceitos o único considerado constante, ou seja, com baixo número de relações e alta freqüência, é a perturbação, o qual apresenta 15 relações e uma freqüência de $44 \%$. Este fato pode ser relacionado ao direcionamento que se é feito no ensino do tópico equilíbrio químico, durante o ensino médio, que comumente dá grande ênfase a este aspecto do tema.

Por se tratar de um conceito mais específico, perturbação aparece relacionado em poucos mapas (aluno 9, aluno 13 e aluno 43), para relacioná-lo os alunos precisam ter o domínio sobre os conceitos a serem ligados e 
descritos. Dentre os três mapas que foram relacionados o conceito perturbação, dois deles apresentaram uma proposição pouco expressiva:

Equilíbrio químico $\rightarrow$ pode sofrer $\rightarrow$ perturbação

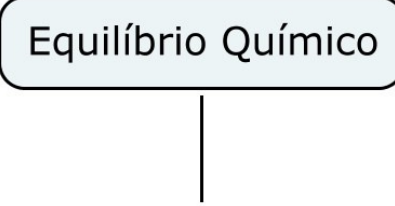

pode sofrer

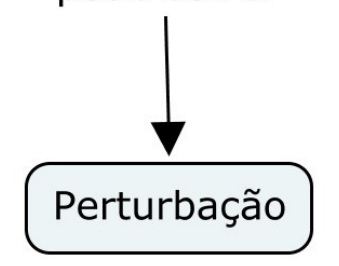

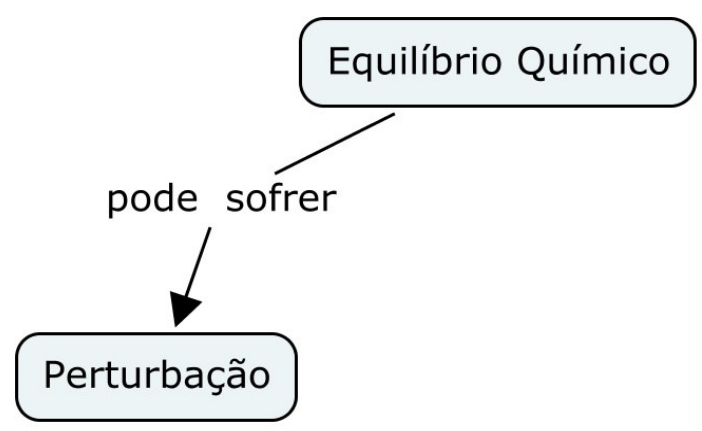

Figura 42-proposição aluno_13

Figura 41-proposição aluno_9

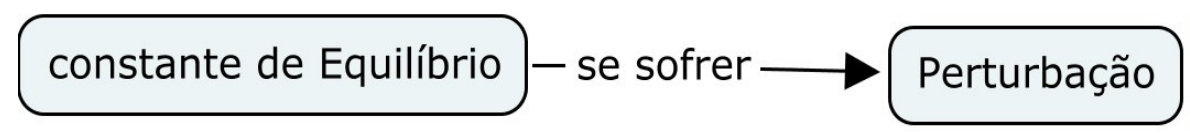

Figura 43-proposição aluno_43

Entre os conceitos classificados como raros, baixo número de relações e baixa porcentagem de freqüência, os conceitos macroscópico e microscópico aparecem relacionados em seis dos dezessete mapas (35\%) com apenas 7 relações e apresentando frases de ligação pouco significativas:

Reação química $\rightarrow$ pode ser representada $\rightarrow$ microscópico

Perturbação $\rightarrow$ que podem ser $\rightarrow$ macroscópico

De acordo com Machado e Aragão (1996) os alunos têm dificuldade em diferenciar o fenômeno de sua representação. A representação macroscópica de um fenômeno microscópico, a questão dos choques entre as moléculas são aspectos mais complexos para compreensão dos alunos. Em virtude da dificuldade em lidar com conceitos como Energia livre e Entropia, os quais não aparecem relacionados em nenhum dos mapas construídos pelos alunos, fato 
que corrobora com nossa inferência sobre como o ensino do equilíbrio químico é pautado no ensino médio; uma abordagem com caráter cinético.
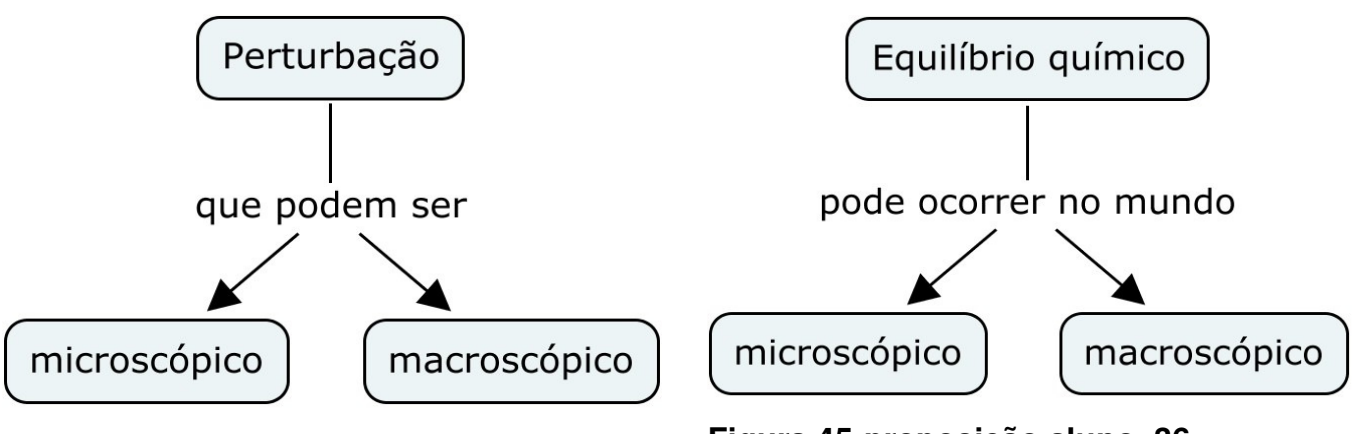

Figura 44-proposição aluno_13

Figura 45-proposição aluno_36

Com propósito de comparar as amostras coletadas aplicou-se a mesma metodologia após um ano de curso com os mesmos 17 alunos ingressantes, transformando os mapas construídos em matriz, obtendo-se a matriz soma e gráfico bidimensional

Dentre os conceitos classificados como dominantes, alto número de relações e alto valor de frequência (Tabela 4, Figura 46 e Figura 47), além dos mesmos apresentados na amostra anteriormente, estão relacionados: perturbação, pressão e reação direta.

$\mathrm{Na}$ primeira aplicação da metodologia o conceito perturbação foi classificado como constante, baixo número de relações e alto número de freqüência, apresentava 15 Relações e posteriormente este obteve 47 Relações (dominante), velocidade de reações foi classificado como dominante com 36 Relações e após a nova aplicação da construção dos mapas este conceito obteve 19 Relações, sendo classificado como constante.

De acordo com as mudanças de categoria entre os conceitos podemos relacionar este evento ao contexto em que é estudado o tópico equilíbrio químico no ensino médio, de maneira a relacionar o estado de equilíbrio à velocidade de reação, visto que no momento da aplicação da construção dos mapas conceituais os alunos ingressantes não tinham sido submetidos ao estudo do tópico equilíbrio químico. 
Podemos inferir, pelo número de relações apontadas nos mapas, que o conceito perturbação foi melhor compreendido e portanto mais relacionado, este conceito nesta segunda fase foi classificado como dominante, perturbação está ligado a compreensão do principio de Le Chatelier, de acordo com Canzian e Maximiano (2010) este é apontado pelos livros didáticos de ensino médio de maneira geral de forma memorística sem relações experimentais sem fundamentação teórica.

Entre os conceitos classificados como raros, baixo número de relações e baixo número de freqüência, além dos que haviam sido relacionados e classificados na primeira aplicação dos mapas, foram verificados nesta fase: endotérmico, potencial químico, variação de energia livre $(\Delta G)$, variação de energia livre padrão $(\Delta G)$ e volume. Ressalta-se que os conceitos potencial químico, variação de energia livre $(\Delta G)$ e variação de energia livre padrão $(\Delta G)$ na primeira amostragem, com os alunos ingressantes, não foram relacionados em nenhum dos dezessete mapas construídos pelos alunos e nesta coleta os mesmos foram relacionados, ainda que em número reduzido: potencial químico uma relação, variação de energia livre $(\Delta G)$ doze relações $e$ variação de energia livre padrão $(\Delta G)$ foi relacionado quatro vezes. 


\begin{tabular}{|c|c|c|c|c|c|c|c|c|c|c|c|c|c|c|c|c|c|c|c|c|c|c|c|c|c|c|c|c|c|c|c|c|}
\hline & & & 2 & 3 & 4 & 5 & 6 & 7 & 8 & 9 & 101 & 111 & 12 & 131 & 14 & 151 & 16 & 171 & 181 & 192 & & 212 & & 232 & & 52 & & 728 & & R/M & & $\% \mathrm{~F}$ \\
\hline concentração & 1 & & 4 & 3 & 0 & 1 & 0 & 4 & 0 & 0 & 1 & 0 & 0 & 7 & 0 & 0 & 3 & 4 & 0 & 1 & 0 & 0 & 3 & 0 & 0 & 0 & $\begin{array}{ll}0 & 2\end{array}$ & 20 & 33 & 1,9 & 11 & 40,7 \\
\hline de equilí & 2 & 4 & & 0 & 1 & 2 & 0 & 5 & 0 & 0 & 0 & 0 & 0 & 0 & 0 & & 5 & & 0 & & 1 & 3 & & 0 & & & & & 40 & 2,4 & 15 & 55,6 \\
\hline rio & 3 & 3 & 0 & & 1 & 6 & 0 & 1 & 0 & 1 & 0 & 0 & 0 & 6 & 0 & 4 & 2 & 0 & 0 & 3 & 3 & 1 & 0 & 0 & & 0 & & 3 & 40 & 2,4 & 14 & 51,9 \\
\hline nâmi & 4 & 0 & 1 & & & 0 & 0 & 5 & 0 & 0 & 0 & 0 & 0 & 1 & 0 & 0 & 0 & 1 & 0 & 0 & 0 & 0 & 1 & 0 & 0 & 0 & 0 & 0 & 10 & 0,6 & 6 & 22,2 \\
\hline a reação & 5 & 1 & 2 & 6 & 0 & & 1 & 2 & 1 & 0 & 0 & 0 & 0 & 1 & 0 & 1 & 2 & 0 & 0 & 8 & 8 & 1 & 0 & 1 & 1 & 1 & 0 & 0 & 37 & 2,2 & 14 & 51,9 \\
\hline ndot & 6 & 0 & 0 & 0 & 0 & & & 0 & 0 & 0 & 0 & 0 & 0 & 0 & 0 & 0 & 0 & 0 & 0 & 3 & 2 & 9 & 0 & 1 & & 0 & & 0 & 24 & 1,4 & 7 & 25,9 \\
\hline ímico & 7 & 4 & 5 & 1 & 5 & 2 & 0 & & 0 & 1 & 0 & 1 & 1 & 6 & 0 & 6 & 2 & 2 & 0 & 0 & 1 & 9 & & 4 & & 1 & & 3 & 64 & 3,8 & 20 & 74,1 \\
\hline até & 8 & 0 & 0 & 0 & 0 & 1 & 0 & 0 & & 0 & 0 & 0 & 0 & 0 & 0 & 0 & 0 & 0 & 0 & 1 & 3 & 9 & 0 & 0 & & 0 & 1 & 0 & 22 & 1,3 & 5 & 18,5 \\
\hline io & 9 & 0 & 0 & 1 & 0 & 0 & 0 & 1 & 0 & & 0 & 1 & 0 & 0 & 0 & 0 & 0 & 0 & 0 & 0 & 0 & 0 & 0 & 1 & 0 & 0 & 0 & 0 & 4 & 0,2 & 4 & 14,8 \\
\hline $\mathrm{Ide}$ & 10 & 1 & 0 & 0 & 0 & 0 & 0 & 0 & 0 & 0 & & 0 & 0 & 0 & 0 & 0 & 0 & 0 & 0 & 0 & 0 & 0 & 0 & 0 & & 0 & 0 & 0 & 1 & 0,1 & 1 & 3,7 \\
\hline macro & 11 & 0 & 0 & 0 & 0 & 0 & & 1 & & 1 & 0 & & 0 & 2 & 0 & 1 & 0 & 2 & 0 & 0 & 0 & 3 & 1 & 0 & & 0 & & 1 & 14 & 0,8 & 10 & 37 \\
\hline ICro & 12 & 0 & 0 & 0 & 0 & 0 & & 1 & & 0 & 0 & 0 & & 2 & 0 & 0 & 0 & 2 & 0 & 0 & 0 & 3 & 1 & 0 & & 1 & & 0 & 10 & 0,6 & 6 & 22,2 \\
\hline rtu & 13 & 7 & 0 & 6 & 1 & 1 & 0 & 6 & 0 & 0 & 0 & 2 & 2 & & 0 & 8 & 4 & 0 & 0 & 0 & 0 & 0 & 0 & 0 & 7 & 0 & & 3 & 47 & 2,8 & 11 & 40,7 \\
\hline oter & 14 & 0 & 0 & 0 & 0 & 0 & 0 & 0 & 0 & 0 & 0 & 0 & 0 & 0 & & 0 & 0 & 0 & 0 & 0 & 0 & 0 & 0 & 0 & & 1 & 0 & 0 & 1 & 0,1 & 1 & 3,7 \\
\hline & 15 & 0 & 2 & 4 & 0 & 1 & 0 & 6 & 0 & 0 & 0 & 1 & 0 & 8 & 0 & & 5 & 0 & 1 & 1 & 1 & 0 & 0 & 0 & & 0 & & 2 & 34 & 2 & 12 & 44,4 \\
\hline Princl & 16 & 4 & 5 & 2 & 0 & 2 & 0 & 2 & 0 & 0 & 0 & 0 & 0 & 4 & 0 & 5 & & 0 & 0 & 1 & 1 & 1 & 0 & 0 & & 0 & 0 & 2 & 35 & 2,1 & 12 & 44,4 \\
\hline produ & 17 & 3 & 5 & 0 & 1 & 0 & 0 & 2 & 0 & 0 & 0 & 2 & 2 & 0 & 0 & 0 & 0 & & 1 & 2 & 1 & 7 & 6 & 3 & 0 & 0 & & 0 & 35 & 2,1 & 12 & 44,4 \\
\hline $\mathrm{IOC}$ & 18 & 0 & 0 & 0 & 0 & 0 & 0 & 0 & 0 & 0 & 0 & 0 & & 0 & & 1 & 0 & 1 & & 0 & 0 & 0 & 1 & 0 & & 0 & & 0 & 3 & 0,2 & 3 & 11,1 \\
\hline Cิ̃ & 15 & 1 & 1 & 3 & 0 & 8 & 3 & 0 & 1 & 0 & 0 & 0 & 0 & 0 & & 1 & 1 & 2 & 0 & & 0 & 5 & 2 & 1 & & 0 & & 0 & 31 & 1,8 & 14 & 51,9 \\
\hline & 20 & 0 & 1 & 3 & 0 & 8 & 2 & 0 & 3 & 0 & 0 & 0 & 0 & 0 & & 1 & 1 & 2 & 0 & 0 & & 5 & 3 & 1 & & 0 & & 0 & 32 & 1,9 & 13 & 48,1 \\
\hline mica & 21 & 0 & 3 & 1 & 0 & 2 & 9 & 9 & 9 & 0 & 0 & 3 & 3 & 0 & & 0 & 1 & 7 & 0 & 5 & 5 & & 8 & 8 & 0 & 4 & & 0 & 78 & 4,6 & 16 & 59,3 \\
\hline & 22 & 3 & 5 & 0 & 1 & 0 & & 1 & & 0 & 0 & 1 & 1 & 0 & & 0 & & & & 1 & 2 & 8 & & 2 & 0 & 0 & & 0 & 33 & 1,9 & 13 & 48,1 \\
\hline & 2. & 0 & 0 & 0 & 0 & 1 & 1 & 4 & & 1 & 0 & 0 & 0 & & & 0 & & & & & & 8 & 2 & & & & & & 3 & 1,4 & & 37 \\
\hline & 2 & 0 & 2 & 5 & 0 & 1 & 7 & 5 & 7 & 0 & 0 & 1 & 0 & 7 & 0 & 0 & 6 & 0 & & 1 & 1 & 0 & & 0 & & & & 0 & 46 & 2,7 & 13 & 48,1 \\
\hline variaç & 25 & 0 & 1 & 0 & 0 & 1 & 0 & 1 & 0 & 0 & 0 & 0 & 1 & 0 & 1 & 0 & 0 & 0 & 0 & 0 & 0 & 4 & 0 & 1 & & & 0 & 0 & 12 & 0,7 & 9 & 33,3 \\
\hline variaç & 26 & 0 & 0 & 0 & 0 & 0 & 1 & 0 & 1 & 0 & 0 & 0 & 0 & 0 & 0 & 0 & 0 & 0 & & 0 & 0 & & & 0 & & 1 & & 0 & 4 & 0,2 & 4 & 14,8 \\
\hline 100 & 27 & 2 & 2 & 1 & 0 & 0 & & 4 & 0 & 0 & 0 & 1 & & 0 & & 2 & & 0 & & 1 & & & & & & 0 & & & 19 & 1,1 & 12 & 44,4 \\
\hline volume & 28 & 0 & 1 & 3 & 0 & 0 & 0 & 3 & 0 & 0 & 0 & & 1 & 3 & 0 & 2 & 2 & 0 & & 0 & & & & 0 & 0 & & & & 17 & 1 & & 33,3 \\
\hline
\end{tabular}

Figura 46-Matriz final obtida para o grupo de alunos referente a disciplina Q.Inorgânica(após um ano de curso). Em amarelo estão as relações com freqüência maior ou igual a 5 ( $29 \%$ da amostra estudada). 


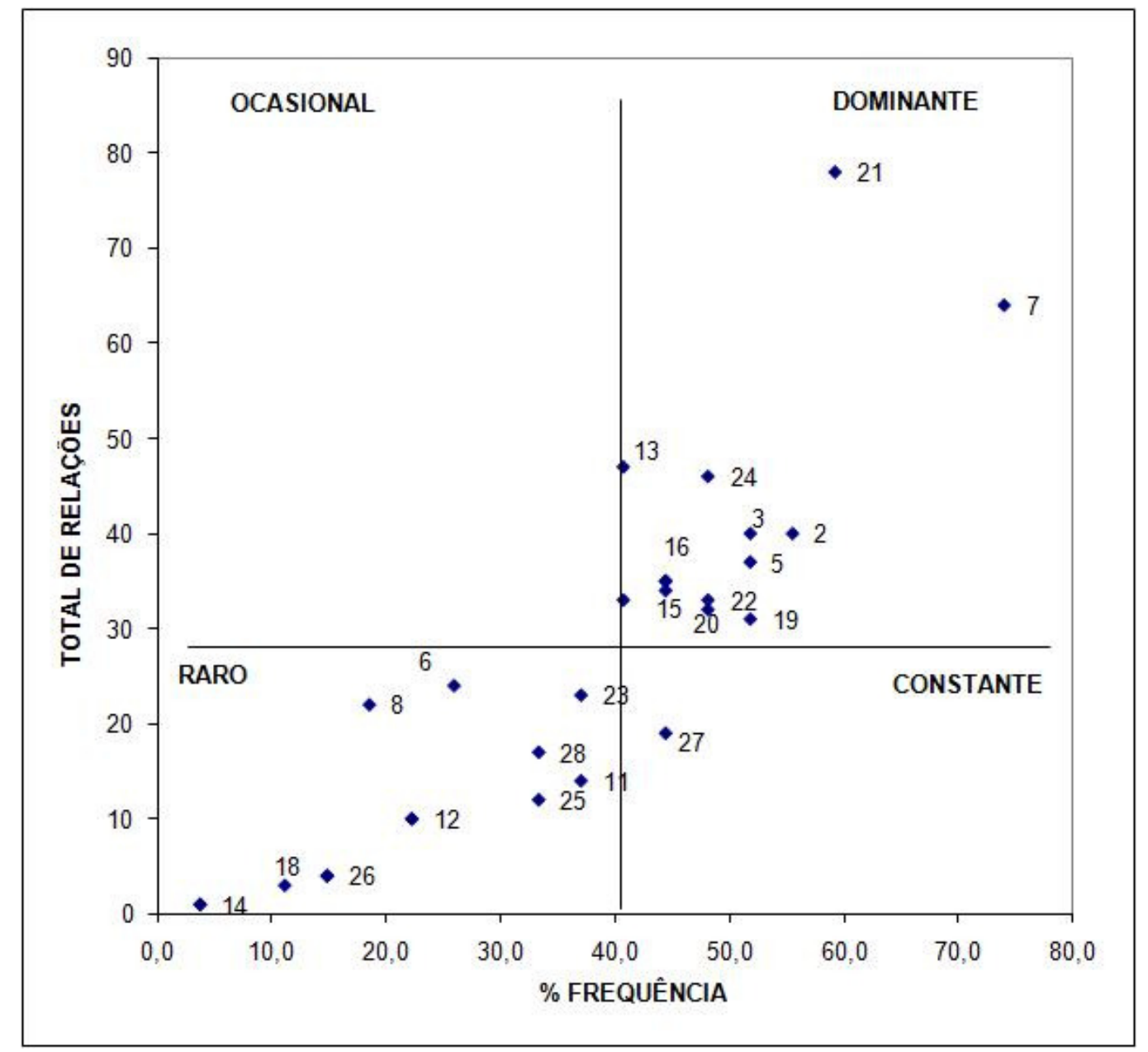

Figura 47-Gráfico obtido a partir da AEMC para os alunos do $1^{\circ}$ ano de 2008. Prova de Associação de Olmstead-Tukey para a matriz soma dos mapas conceituais elaborados pelos alunos referente a disciplina Q.Transformações. Cada ponto corresponde a um conceito: 1-conceito: 1-concentração, 2-constante de equilíbrio (K), 3-deslocamento de equilíbrio, 4-dinâmico, 5-direção da reação, 6-endotérmico, 7-equilíbrio químico, 8exotérmico, 9-extensão da reação, 10-lei de ação das massas, 11-macroscópico, 12 microscópico, 13-perturbação, 14-potencial químico, 15-pressão, 16-princípio de Le Chatelier, 17-produtos, 18-quociente de reação $(Q)$, 19-reação direta, 20-reação inversa, 21-reação química, 22-reagentes, 23-reversível, 24-temperatura, 25-variação de energia livre $(\Delta \mathrm{G})$, 26-variação de energia livre padrão $\left(\Delta \mathrm{G}^{\circ}\right)$, 27-velocidade de reações, 28-volume. 
Tabela 4-Resultados obtidos usando AEMC-Adaptada para os dados dos alunos 1ํano- Transformações Q.e Q.Inorgânica obtidos em 2008

\begin{tabular}{|c|c|c|c|c|}
\hline NOTURNO & Conceitos dominantes & Conceitos ocasionais & Conceitos constantes & Conceitos raros \\
\hline $\begin{array}{l}\text { Resultado obtidos } \\
\text { apenas no grupo } \\
\text { de mapas feitos } \\
\text { antes do estudo do } \\
\text { tema }\end{array}$ & $\begin{array}{l}\text {-Velocidade das reações } \\
\text {-Volume } \\
\end{array}$ & $\begin{array}{l}\text {-endotérmico } \\
\text {-Pressão } \\
\text {-reação direta }\end{array}$ & -perturbação & \\
\hline $\begin{array}{l}\text { Resultado obtidos } \\
\text { apenas no grupo } \\
\text { de mapas feitos } \\
\text { após o estudo do } \\
\text { tema }\end{array}$ & $\begin{array}{l}\text {-reação direta } \\
\text {-perturbação } \\
\text {-pressão }\end{array}$ & & -Velocidade das reações & $\begin{array}{l}\text {-endotérmico } \\
\text {-potencial químico } \\
\text {-Variação de energia livre } \\
(\Delta \mathrm{G}) \\
\text {-Variação de energia livre } \\
\text { padrão }(\Delta \mathrm{G}) \\
\text {-volume }\end{array}$ \\
\hline $\begin{array}{l}\text { Comum aos dois } \\
\text { grupos de mapas } \\
\text { conceituais } \\
\text { coletados }\end{array}$ & $\begin{array}{l}\text {-concentração } \\
\text {-constante de equilíbrio (K) } \\
\text {-deslocamento de equilíbrio } \\
\text {-direção da reação } \\
\text {-Equilíbrio químico } \\
\text {-Princípio de Le Chatelier } \\
\text {-Produtos } \\
\text {-reação inversa } \\
\text {-reação química } \\
\text {-regentes } \\
\text {-temperatura }\end{array}$ & & & $\begin{array}{l}\text {-Dinâmico } \\
\text {-exotérmico } \\
\text {-extensão da reação } \\
\text {-lei de ação das massas } \\
\text {-macroscópico } \\
\text {-microscópico } \\
\text {-quociente de reação (Q) } \\
\text {-reversível }\end{array}$ \\
\hline
\end{tabular}




\subsubsection{QUANTIFICAÇÃO FREQUÊNCIA DE ASSOCIAÇÃO E DO NÚMERO DE RELAÇÕES POR MAPA CONCEITUAL}

Ainda com forte propósito de evidenciar as diferenças apontadas na segunda coleta de dados, estas estão mais bem ilustradas na Tabela 5.

Dentre os 28 conceitos listados as diferenças mais significativas entre as RELAÇÕES/MAPA, para os mapas coletados para alunos ingressantes e após um ano de curso, destacam-se Perturbação, Princípio de Le Chatelier, Reação química e Velocidade das reações. Este conceito foi relacionado $50 \%$ a menos em comparação a primeira amostragem, o que correlaciona com nossa observação de que alunos ingressantes tendem a relacionar a cinética química ao equilíbrio químico.

O conceito Princípio de Le Chatelier foi relacionado pelo menos uma vez a mais a cada mapa, na comparação dos dois momentos da coleta dos mapas, demonstrando que este foi melhor compreendido e por tanto relacionado.

Pode-se também observar diferenças expressivas entre as FREQUÊNCIAS DE ASSOCIAÇÕES, dentre os conceitos os que apresentam diferenças mais relevantes são Macroscópico, Reação direta, Reversível, Variação de energia livre e Variação de energia livre padrão.

A freqüência de associações foi alterada de maneira muito significante para os conceitos citados, na comparação dos mapas dos alunos ingressantes e após um ano de curso, Macroscópico, Reação direta e Reversível apresentam o dobro de freqüência; pode-se inferir que um conceito que é mais freqüente é aquele que foi mais bem entendido, portanto, verifica-se uma evolução na compreensão dos mesmos.

Os conceitos relacionados à termodinâmica, Variação de energia livre e Variação de energia livre padrão não foram relacionados, ou seja, a freqüência de associação destes conceitos na primeira amostragem foi zero, já nos mapas construídos pelos alunos após um ano de curso estes conceitos obtiveram suas freqüências de associações de zero para nove e de zero para quatro, de acordo com os apontamentos demonstrados na tabela. 
Este apontamento nos direciona para o entendimento de que ao ingressar os estudantes não possuem o domínio de alguns conceitos, porém ao cursarem disciplinas que abordam estes conceitos os alunos demonstraram através da construção dos mapas que houve uma compreensão dos mesmos.

Da mesma forma que a cinética foi muito relacionada nos mapas construídos pelos ingressantes após estes terem sido submetidos ao estudo da termodinâmica, a cinética química apontada através do conceito velocidade das reações, obteve sua freqüência de associação reduzida de quinze para doze. 
Tabela 5- FREQUÊNCIA DE ASSOCIAÇÃO E RELAÇÕES/MAPA

\begin{tabular}{|c|c|c|c|c|c|c|c|c|c|c|c|}
\hline & 2008 & & pas & & & & ma & o cur & & & \\
\hline & & 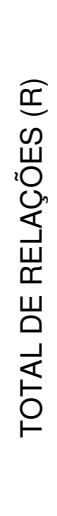 & 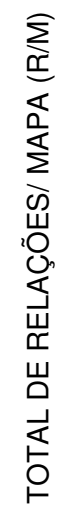 & 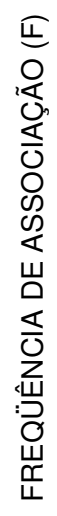 & 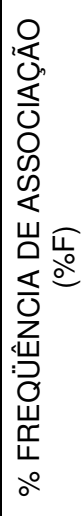 & 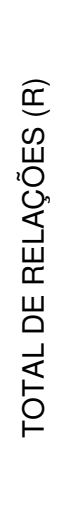 & 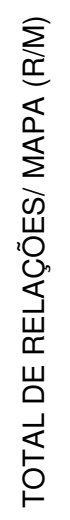 & 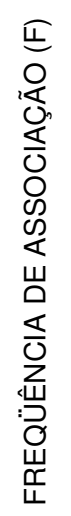 & 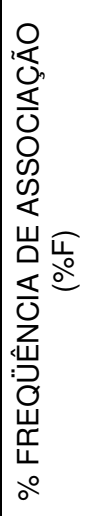 & 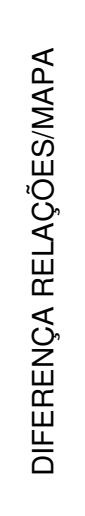 & 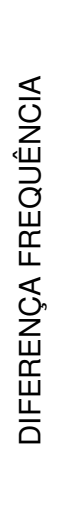 \\
\hline 1 & concentração & 39 & 2,3 & 12 & 70,6 & 33 & 1,9 & 11 & 40,7 & 0,4 & 1 \\
\hline 2 & constante de equilíbrio (K) & 38 & 2,2 & 12 & 44,4 & 40 & 2,4 & 15 & 55,6 & $-0,2$ & 3 \\
\hline 3 & deslocamento de equilíbrio & 52 & 3,1 & 17 & 63 & 40 & 2,4 & 14 & 51,9 & 0,7 & 3 \\
\hline 4 & dinâmico & 13 & 0,8 & 7 & 25,9 & 10 & 0,6 & 6 & 22,2 & 0,2 & 1 \\
\hline 5 & direção da reação & 44 & 2,6 & 17 & 63 & 37 & 2,2 & 14 & 51,9 & 0,4 & 3 \\
\hline 6 & endotérmico & 18 & 1,1 & 6 & 22,2 & 24 & 1,4 & 7 & 25,9 & 0,3 & -1 \\
\hline 7 & equilíbrio químico & 51 & 3 & 17 & 63 & 64 & 3,8 & 20 & 74,1 & $-0,8$ & -3 \\
\hline 8 & exotérmico & 17 & 1 & 7 & 25,9 & 22 & 1,3 & 5 & 18,5 & $-0,3$ & 2 \\
\hline 9 & extensão de reação & 2 & 0,1 & 1 & 3,7 & 4 & 0,2 & 4 & 14,8 & $-0,1$ & -3 \\
\hline 10 & Lei de ação das massas & 2 & 0,1 & 2 & 7,41 & 1 & 0,1 & 1 & 3,7 & 0 & 1 \\
\hline 11 & macroscópico & 7 & 0,4 & 5 & 18,5 & 14 & 0,8 & 10 & 37 & $-0,4$ & -5 \\
\hline 12 & microscópico & 7 & 0,4 & 5 & 18,5 & 10 & 0,6 & 6 & 22,2 & $-0,2$ & -1 \\
\hline 13 & perturbação & 15 & 0,9 & 12 & 44,4 & 47 & 2,8 & 11 & 40,7 & $-1,9$ & 1 \\
\hline 14 & potencial químico & 0 & 0 & 0 & 0 & 1 & 0,1 & 1 & 3,7 & $-0,1$ & -1 \\
\hline 15 & pressão & 28 & 1,6 & 9 & 33,3 & 34 & 2 & 12 & 44,4 & $-0,4$ & -3 \\
\hline 16 & princípio de Le Chatelier & 19 & 1,1 & 11 & 40,7 & 35 & 2,1 & 12 & 44,4 & -1 & -1 \\
\hline 17 & produtos & 34 & 2 & 13 & 48,1 & 35 & 2,1 & 12 & 44,4 & $-0,1$ & 1 \\
\hline 18 & quociente de reação (Q) & 3 & 0,2 & 3 & 11,1 & 3 & 0,2 & 3 & 11,1 & 0 & 0 \\
\hline 19 & reação direta & 25 & 1,5 & 7 & 25,9 & 31 & 1,8 & 14 & 51,9 & $-0,3$ & -7 \\
\hline 20 & reação inversa & 29 & 1,7 & 10 & 37 & 32 & 1,9 & 13 & 48,1 & $-0,2$ & -3 \\
\hline 21 & reação química & 63 & 3,7 & 18 & 66,7 & 78 & 4,6 & 16 & 59,3 & $-0,9$ & 2 \\
\hline 22 & reagentes & 33 & 1,9 & 11 & 40,7 & 33 & 1,9 & 13 & 48,1 & 0 & -2 \\
\hline 23 & reversível & 13 & 0,8 & 6 & 22,2 & 23 & 1,4 & 10 & 37 & $-0,6$ & -4 \\
\hline 24 & temperatura & 43 & 2,5 & 10 & 37 & 46 & 2,7 & 13 & 48,1 & $-0,2$ & -3 \\
\hline 25 & variação de energia livre $(\Delta \mathrm{G})$ & 0 & 0 & 0 & 0 & 12 & 0,7 & 9 & 33,3 & $-0,7$ & -9 \\
\hline 26 & variação de energia livre padrão $\left(\Delta \mathrm{G}^{\circ}\right)$ & 0 & 0 & 0 & 0 & 4 & 0,2 & 4 & 14,8 & $-0,2$ & -4 \\
\hline 27 & velocidade de reações & 36 & 2,1 & 15 & 55,6 & 19 & 1,1 & 12 & 44,4 & 1 & -3 \\
\hline 28 & volume & 19 & 1,1 & 10 & 37 & 17 & 1 & 9 & 33,3 & 0,1 & -1 \\
\hline
\end{tabular}




\subsubsection{MAPA CONCEITUAL REPRESENTIVO}

Com o propósito de verificar e comparar as duas amostras, alunos ingressantes e após um ano de curso, foi construído um mapa representativo (Figura 48 e Figura 49 para cada momento da coleta de dados, a partir das matrizes finais (Figura 39 e Figura 46). Para uma melhor comparação destes mapas relacionamos os conceitos presentes nos dois mapas representativos, Tabela 6 .

Tabela 6-conceitos presentes nos mapas representativos

\begin{tabular}{|l|l|}
\hline & $\begin{array}{l}\text { Conceitos presentes nos mapas } \\
\text { representativos }\end{array}$ \\
\hline $\begin{array}{l}\text { Conceitos presentes apenas no } \\
\text { mapa representativo obtido antes do } \\
\text { estudo do tema. }\end{array}$ & Velocidade das reações \\
\hline $\begin{array}{l}\text { Conceitos presentes apenas no } \\
\text { mapa representativo obtido após do } \\
\text { estudo do tema. }\end{array}$ & Perturbação \\
\hline $\begin{array}{l}\text { Conceitos presentes nos dois mapas } \\
\text { conceituais representativos. }\end{array}$ & Concentração \\
& Constante de equilíbrio \\
& Deslocamento de equilíbrio \\
& Dinâmico \\
& Direção da reação \\
& Endotérmico \\
& Equilíbrio químico \\
& Exotérmico \\
& Pressão \\
& Princípio de Le Chatelier \\
& Produtos \\
& Reação direta \\
& Reação inversa \\
Reação química \\
Reagentes \\
Temperatura \\
\hline
\end{tabular}




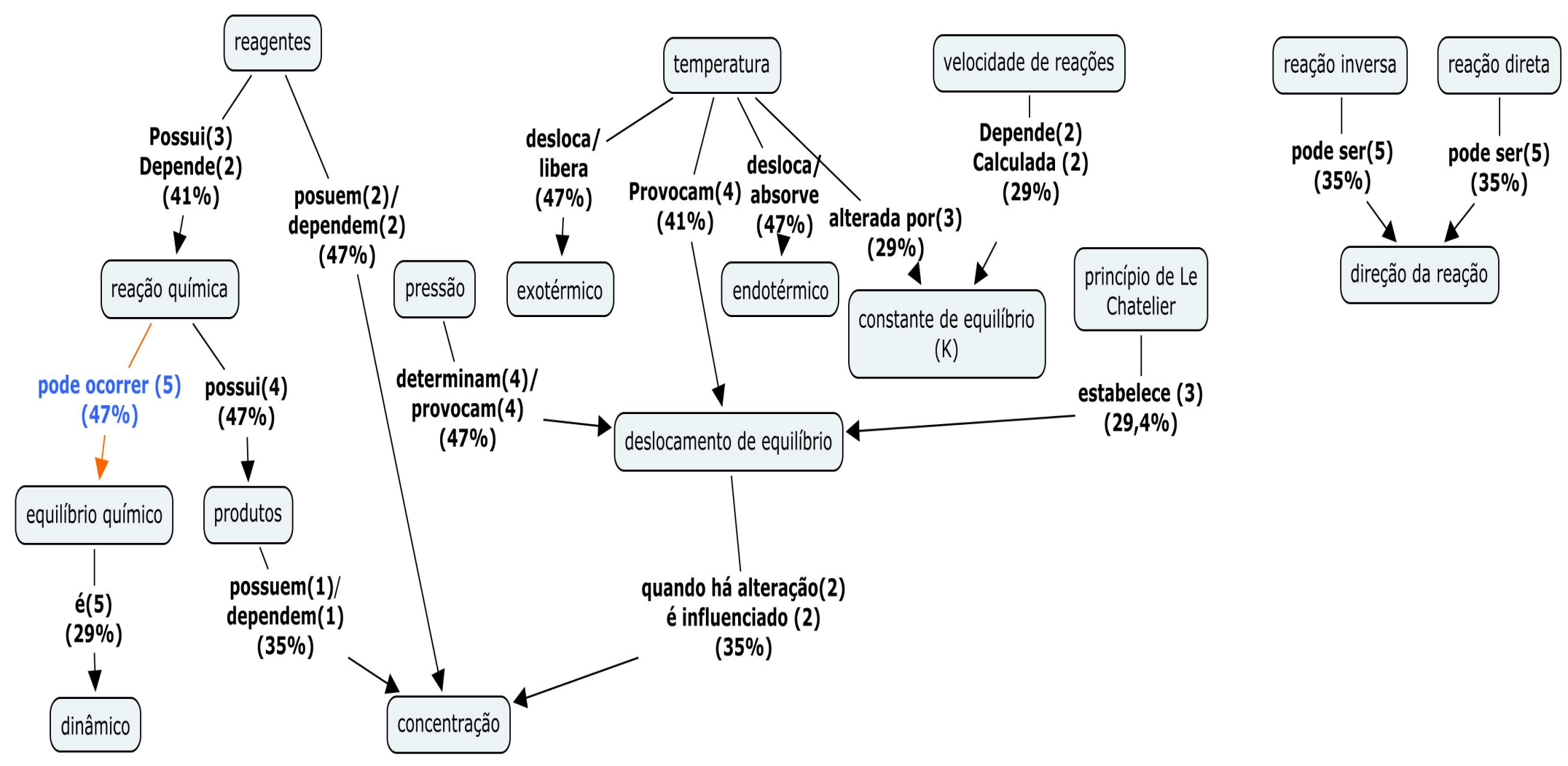

Figura 48-Mapa conceitual obtido para o grupo de alunos da disciplina Transformações Químicas. O porcentual presente nas frases de ligação expressa a freqüência de ligação entre os conceitos. Entre parênteses está o número de ocorrência da frase de ligação. 


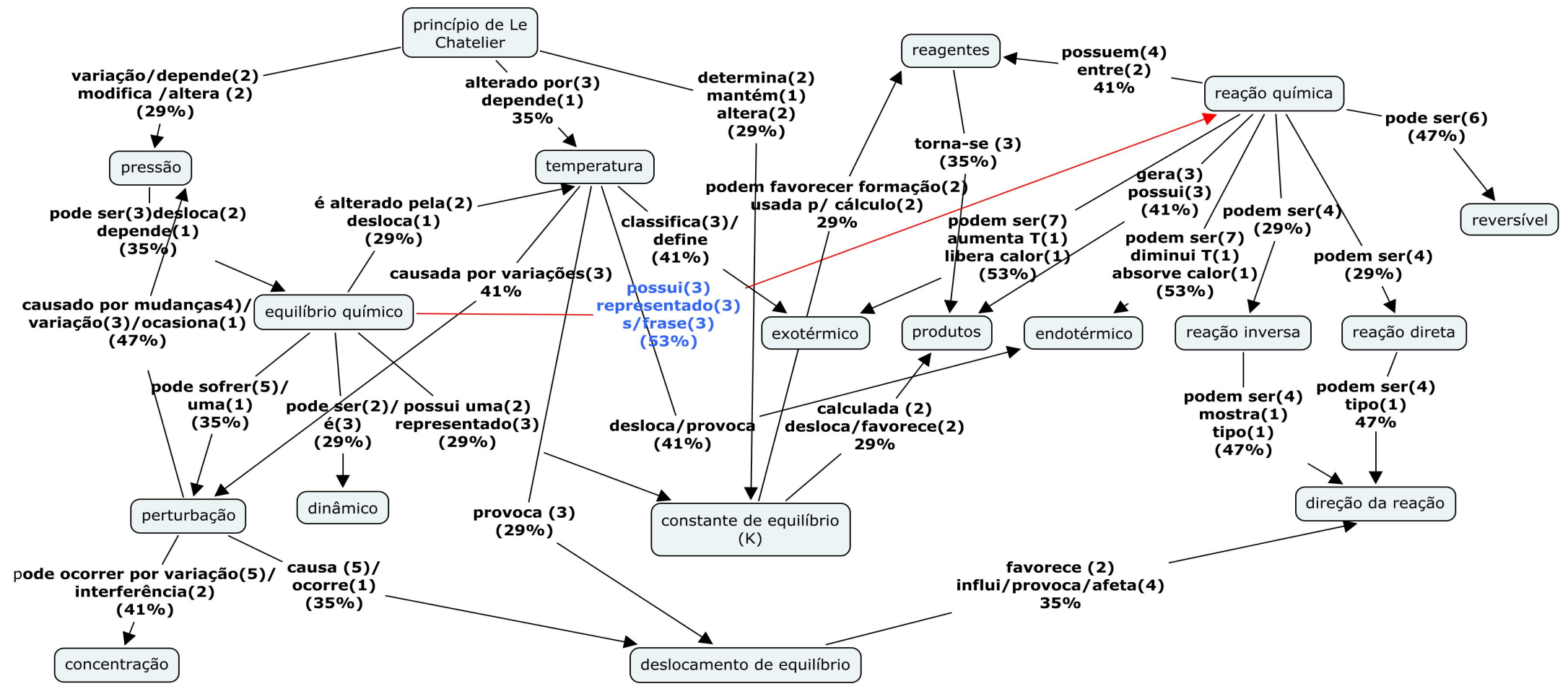

Figura 49-Mapa conceitual obtido para o grupo de alunos da disciplina Química Inorgânica. O porcentual presente nas frases de ligação expressa a freqüência de ligação entre os conceitos. Entre parênteses está o número de ocorrência da frase de ligação. 
O mapa conceitual representativo obtido após um ano de ingresso dos alunos, apresenta 18 conceitos e 29 proposições, já o mapa representativo da primeira amostragem, momento em que os estudantes eram ingressantes e cursando a disciplina Introdução as transformações químicas apresentou 17 conceitos e apenas 16 proposições. As proposições verificadas no mapa referente a Transformações são muito óbvias e simplificadas, ou ainda inválidas, como:

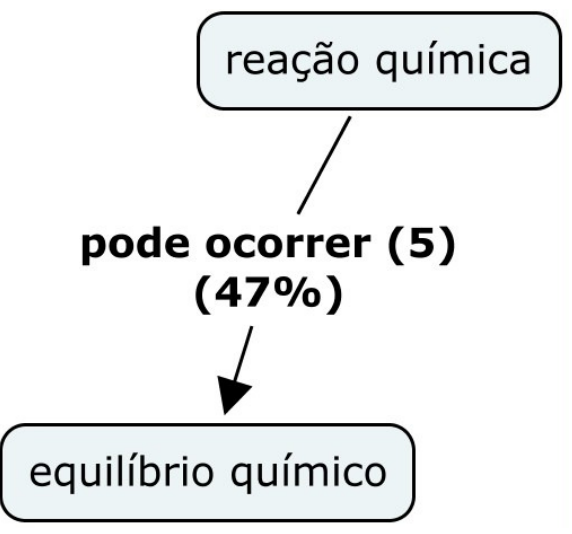

Figura 50- proposição mapa representativo dos alunos ingressantes

A proposição foi relacionada em $47 \%$ dos mapas analisados, onde a frase de ligação foi proposta por 5 dos 8 alunos que relacionaram esses conceitos.

Com a obtenção do mapa representativo, foi possível verificar que, o conceito reversível está ligado à reação química em 47\% (8 dos 17) dos mapas construídos pelos alunos, referente à Química Inorgânica; já no mapa construído no momento em que os ingressantes cursavam a disciplina Introdução as Transformações Químicas, o número de ligações com este conceito foi menor que 5 dos 17 mapas analisados, abaixo de $25 \%$ do total.

O aumento da freqüência de associações do conceito de reversibilidade foi verificado em vários apontamentos já relatados, pode-se concluir que este foi melhor entendido por parte dos estudantes após terem sido submetidos ao estudo de disciplinas relacionadas á química. 
No mapa representativo referente a primeira amostragem (alunos ingressantes) o único conceito classificado como constante, ou seja, com baixo número de relações e alta freqüência, é perturbação, este apresenta uma freqüência nos mapas construídos pelos alunos de 15\%, portanto abaixo de 25\% não sendo apreciável no mapa representativo, entretanto no mapa representativo relativos a Química Inorgânica este conceito foi classificado como dominante, apresentando $41 \%$ de relações mostrando assim que o conceito que era mais específico foi melhor entendido pelos alunos passando a ser um conceito dominante.

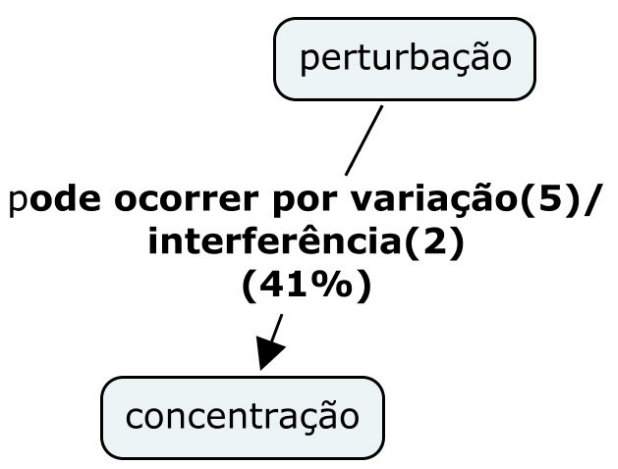

Figura 51-proposição mapa representativo dos alunos após um ano de curso

Na primeira construção dos mapas conceituais, o conceito Perturbação recebeu um total de 15 relações nos 17 mapas construídos, não sendo apreciável no mapa representativo da turma, acredita-se que este fato deve-se por tratar de um conceito mais específico, já nos mapas construídos pelos estudantes na segunda amostragem o conceito recebeu 47 relações nos 17 mapas.

Dos 17 mapas construídos pelos alunos 11 deles relacionou o conceito Perturbação, além de apresentarem frases de ligações mais elaboradas, como:

Perturbação $\rightarrow$ pode ocorrer por variação $\rightarrow$ temperatura

Muito recorrente em nossos apontamentos, o conceito velocidade de reações foi relacionado em 15 dos 17 mapas construídos pelos alunos ingressantes, sendo um conceito classificado como dominante, nos mapas também verifica-se relações simplistas e freqüentes muito características, 
apontando para uma estrutura média dos alunos na qual a definição do equilíbrio químico está pautado na cinética química e não na termodinâmica.

Comparando o mapa representativo dos alunos ingressantes com 0 mapa representativo dos alunos após um ano de curso, ficam evidentes as diferenças o conceito Velocidade de reações com $29 \%$ freqüência de ligações e um total de relações de 36 nos 17 mapas construídos; aparece ligado ao conceito Constante de Equilíbrio $(\mathrm{K})$. Como já mencionado acredita-se que este deve-se ao fato dos alunos ingressantes relacionarem a cinética química como a explicação para o sistema atingir o equilíbrio.

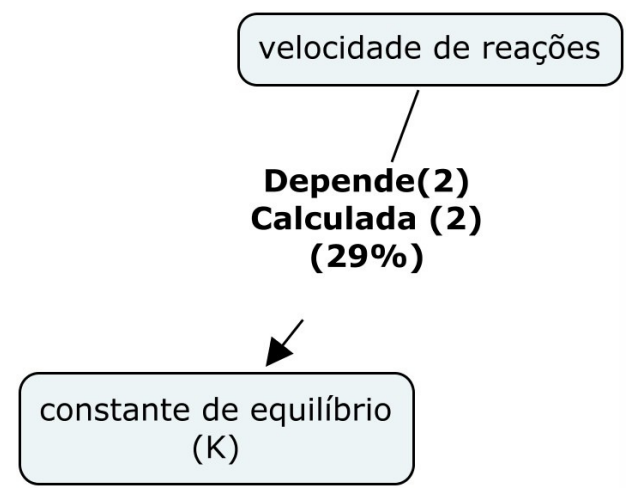

Figura 52-proposição mapa representativo dos alunos ingressantes

No mapa representativo da turma após um ano de curso, o conceito Velocidade de reações não foi muito utilizado, não obtendo pelo menos $29 \%$ de freqüência de ligações, ou seja, dos 17 mapas construídos pelos alunos menos que 5 deles fizeram relações com este conceito. Verificamos também que o total de relações nesta fase foi de 19 e na primeira amostragem este era de 36 .

Princípio de Le Chatelier aparece no mapa representativo dos alunos ingressantes de maneira pouco expressiva, com $29 \%$ de freqüência de relações, e ligado ao conceito Deslocamento de equilíbrio, já no mapa representativo da segunda amostragem Princípio de Le Chatelier este conceito é apontado a três conceitos Temperatura com 35\%, Pressão e Constante de Equilíbrio com 29\%, de freqüência de relações.

Verifica-se também, proposições inalteradas relacionadas a conceitos mais óbvios, como: 


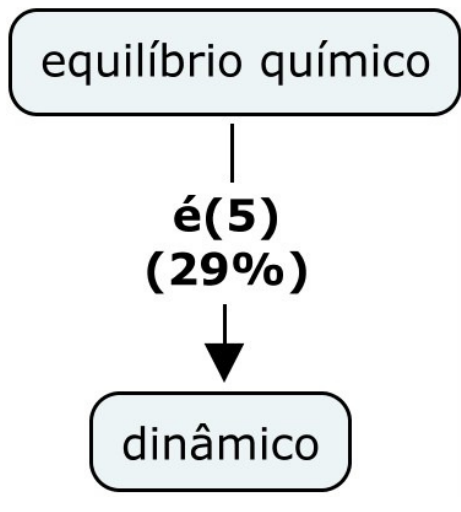

Figura 53-proposição mapa representativo dos alunos ingressantes

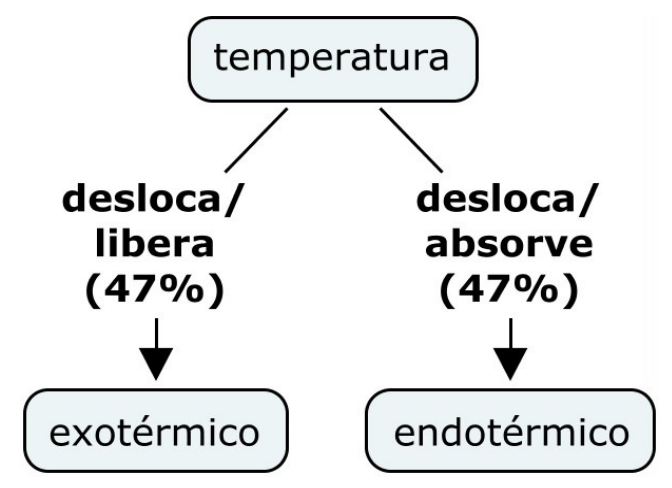

Figura 55-proposição mapa representativo dos alunos ingressantes

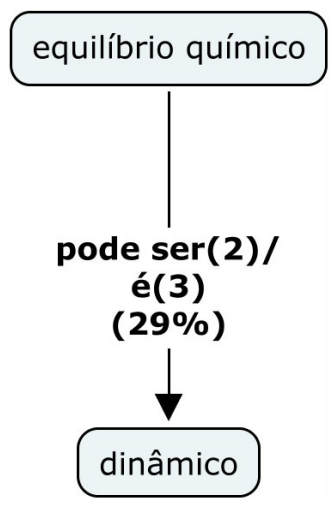

Figura 54-proposição mapa representativo dos alunos após um ano de curso

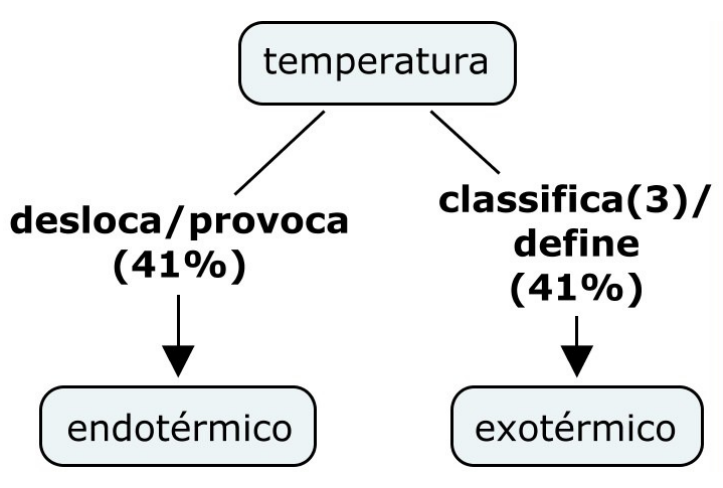

Figura 56-proposição mapa representativo dos alunos após um ano de curso 


\section{CONCLUSÕES}

A aplicação da AEMC-ADAPTADA permitiu: a) classificar como um grande número de conceitos relacionados ao tema equilíbrio químico está presente hierarquia conceitual dos alunos; b) obter mapas conceituais representativos que apontem para uma estrutura conceitual média dos mesmos; c) comparar as diferenças entre mapas conceituais elaborados por alunos pertencentes a diferentes grupos (cursos diurno e noturno) e para os mesmos alunos em momentos distintos durante o período de estudo.

A aplicação da AEMC-ADAPTADA não é o único método de análise de mapas conceituais e não elimina a possibilidade de se utilizar outros métodos que comparam o número de nós e ligações entre diferentes mapas, a qualidade das relações (Francisco et al, 2002), as relações hierárquicas entre os conceitos (Almeida, 2003) ou a comparação com um mapa conceitual padrão.

A obtenção da matriz final para cada grupo estudado é, em particular, uma ferramenta útil para analisar possíveis relações conceituais de interesse, como por exemplo, verificar se existem, quando surgem e qual a natureza de relações entre os conceitos variação de energia livre padrão $\left(\Delta G^{\circ}\right) e$ constante de equilíbrio $(K)$ ou de quociente de reação $(Q)$ e variação de energia livre $(\Delta G)$ que denotaria um entendimento maior das relações entre a espontaneidade de uma reação e da aproximação de um sistema químico do estado de equilíbrio.

Quanto à análise das estruturas conceituais dos alunos a respeito do tema Equilíbrio químico, os resultados obtidos apontam que em geral os alunos: a) definem o Equilíbrio químico como o estado onde as velocidades das reações direta e inversa se igualam (lei de ação das massas, sendo que não houve relação a conceitos termodinâmicos apontados para os alunos ingressantes; b) relacionam as possíveis alterações do estado de equilíbrio químico devido a variação de variáveis do sistema com o Princípio de Le 
Chatelier e não consideram a possibilidade de comparar o quociente de reação (Q) com a constante de equilíbrio.

Os apontamentos sugerem que os alunos ao ingressarem no ensino superior trazem em sua estrutura de conhecimentos conceitos oriundos do que é apresentado no ensino médio e estes se modificam ao serem submetidos à disciplinas relacionadas ao estudo do tópico equilíbrio químico. De grande valia poderíamos realizar o mesmo trabalho aqui proposto após cada disciplina oferecida pelo Instituto de Química da Universidade de São Paulo, de maneira a aprofundar na contribuição que cada disciplina oferece ao conhecimento e modificação dos estudantes.

Deste modo, as questões apresentadas:

É possível avaliar a compreensão dos alunos em um determinado assunto? Se aplicada a técnica de mapeamento conceitual em momentos diferentes de um curso, será possível verificar uma possível evolução de conceitos? E finalmente, o mapeamento conceitual pode ser utilizado como uma ferramenta eficaz para verificar a estrutura conceitual dos alunos?

Através dos resultados discutidos e apontados durante a exposição da pesquisa realizada, verifica-se que a ferramenta apresentada foi muito útil para responder as questões propostas como objetivo deste trabalho.

Verifica-se que a utilização de mapas conceituais centra-se na variação da qualidade e complexidade da estrutura cognitiva dos alunos, o trabalho apresentado pretende corroborar para 0 ensino por apresentar uma metodologia eficaz na verificação da estrutura conceitual dos alunos bem como uma ferramenta útil para o docente. 


\section{BIBLIOGRAFIA}

ALMEIDA, F.C.P., et al., Mapas conceituais: avaliando a compreensão do alunos sobre o experimento do efeito fotoelétrico, IV Encontro Nacional de Pesquisa em Educação em Ciências, 2003

ARBEA, J.; CAMPO, F.D. Mapas Conceptuales y aprendizaje significativo de las ciências naturales: análisis de los mapas conceptuales realizados antes y después de la implementación de um módulo intruccional sobre la energia. 2004. Disponível em: <http://cmc.inmc.us/papers/cmc2004-148.pdf>. Acesso em: 08/02/2008.

ARAÚJO, N.R.S.; et al. Mapas conceituais como estratégia de avaliação. Semina: Ciências Exatas e Tecnológicas, v.28, n.1, p.47-54, jan.-jun., 2007.

AUSUBEL, D.P.; NOVAK, J.D.; HANESIAN, H. Psicologia Educacional. Rio de Janeiro: Interamericana, 1980. 625 p.

BALL, David W.; Físico-química.Thomson, 2005, 877 p. 3ª Ed., Rio de Janeiro: LTC, $410 \mathrm{p}$.

BEYERBACH, B. A.; SMITH, J. M. Using a computerized concept mapping program to assess preservice teachers' thinking about effective teaching. Journal of Research in Science Teaching (Special Issue), v.27, n.10, p.961-971, 1990.

CAMACHO, M. e GOOD, R., Problem solving and chemical equilibrium, Journal of Research in Science Teaching, v. 26, p. 251-272, 1989.

CAÑAS,, A. J., NOVAK, J. D., y GONZÁLEZ FERMÍN, Eds. (2004). Concept Maps: Theory, Methodology, Technology. Proc. of the 1st Int. Conf. on Concept Mapping. Vol. 1. Pamplona: Universidad Pública de Navarra.

CANZIAN, R. E MAXIMIANO, F. A., Princípio de Le Chatelier - O que tem sido apresentado em livros didáticos? Química Nova na Escola, v. 32, n. 2, p. 107-119, 2010. (http://qnesc.sbq.org.br/online/qnesc32_2/)

CLARIANA, R., KOUL, R.e ALBRIGHT, K. , Using Pathfinder Knot Analytic tools for comparing and Combining concept maps http

Disponível em: <http://www.personal.psu.edu/rbc4/CMC 2006.htm Acesso em: 08/01/2009. 
COSTAMAGNA, A. M. Mapas conceptuales como expresión de procesos de interrelación para evaluar la evolución del conocimiento de alumnos universitarios. Enseñanza de Las Ciências, v.19, n.2, p.309-318, 2001.

DERBENTSEVA, N.; SAFAYENI, F.; CAÑAS, A. J. Concept maps: experiments on dynamic thinking. Journal of Research in Science Teaching, v.44, n.3, p.448-465, 2007.

FRANCISCO, J.S., et al. Assessing student understanding of general chemistry with concept mapping. Journal of Chemical Education, v.79, n.2, p.248-257, fev. 2002.

FREITAS FILHO, J. R. Mapas conceituais: estratégia pedagógica para construção de conhecimento na disciplina química orgânica. Ciência e Cognição. V. 12, p. 86-95, 2007.

FURIO-MAS, C. J. e ORTIZ, E., 1983, Persistência de errores conceptuales em el estúdio del equilíbrio químico, Enseñanza de las Ciências, 1 (1), 15-21.

FURIÓ. C; FURIÓ, C. "Dificuldades conceptuales y epistemológicas em el aprendizaje de los procesos químicos. Educación química, v.11, n.3, p.300-308, 2000.

GARCÍA de LEÓN, L. A. Generalidades del análisis de cúmulos del análisis de componentes principales. México: Instituto de Geografía, UNAM.1988

GONZÁLEZ YOVAL, P., et. al., Análisis Estructural de mapas conceptuales (AEMC): Revisión de La evidencia empírica de 2004 al 2010 Proceedings of the Fourth International Conference on Concept Mapping p. 23, 2010 Disponível em: http://cmc.ihmc.us/cmc2010papers/cmc2010-a31.pdf Acesso em: 30 de outubro de 2010

GONZÁLEZ YOVAL, P., et. al., A proposal to refine SACMap technique (Structural Analysis of Concept Maps) AMID A STS-Webquest context. Concept Maps: Theory, Methodology, Technology: Proceedings of the Third International Conference on Concept Mapping. p. 207, 2008. Disponível em: <http://cmc.ihmc.us/cmc2008papers/cmc2008-p207.pdf> Acesso em: 08 de julho de 2009.

GONZÁLEZ YOVAL, P., et. al., Aplicación de la técnica de análisis estructural de mapas conceptuales (AEMC) en un contexto de educación CTS. Concept Maps: Theory, Methodology, Technology: Proceedings of the Second International Conference on Concept Mapping, p. 202, 2006. Disponível em: <http://cmc.inmc.us/cmc2006Papers/cmc2006-p202.pdf> Acesso em: 08 de julho de 2009. 
GONZÁLEZ-YOVAL, P., et. al., Valoración cuantitativa para evaluar mapas conceptuales. Concept Maps: Theory, Methodology, Technology: Proceedings of the First International Conference on Concept Mapping, p. 289, 2004. Disponível em: <http://cmc.ihmc.us/papers/cmc2004-248.pdf> Acesso em: 08 de julho de 2009.

KAYA, O. S. A student-centred approach: Assessing the changes in prospective science teachers' conceptual understanding by concept mapping in a general chemistry laboratory. Research in Science Education.38 (1), 91-110. (Indexed in Social Sciences Citation Index-SSCI).2008 Disponível em: http://perweb.firat.ed Acesso em: 08 de novembro de 2010.

KOTZ, J.C. e TREICHEL, P. Química e Reações Químicas, Rio de Janeiro: LTC, 2002.

JOHNSTONE, A.H. Learning Dificulties in Chemistry: Na Overview Journal Turkish Science Education, vol.4, n.2, 2007

LLOYD, C.V. The elaboration of concepts in three biology textbooks: facilitating student learning. Journal of Research in Science Teaching (Special Issue), v.27, n.10, p.1019-1032, 1990.

LOURENÇO, B.A., Análise de mapas conceituais elaborados por alunos da oitava série do ensino fundamental a partir de aulas pautadas na teoria da aprendizagem significativa: a argila como tema de estudo, Dissertação de mestrado em educação, Universidade Federal de São Carlos, 2008

MACHADO, A. H.; ARAGÃO, R. M. R. de. Como os estudantes concebem o estado de equilíbrio químico. Química Nova na Escola, São Paulo, n. 4, p. 18-20, nov. 1996.

MARKOW, P.G.; LONNING R.A. Usefulness of concept maps in college chemistry laboratories: students' perceptions and effects on achievement. Journal of Research in Science Teaching, v.35, n.9, p.1015-1029, 1998.

MASKILL, R e CACHAPUZ, A F C,. Learning about the chemistry topic of equilibrium: The use of Word association tests to detect development conceptualizations. International Journal of Science Education, 11, 57-69, 1989.

MENDONÇA, Paula C.C; Justi, Rosária S.; Ferreira, Poliana F.M - Analogias usadas no Ensino de Equilíbrio Químico- Minas Gerais, VII Congresso Enseñanca de Lãs Ciências- número extra, 2005 
MCCLURE, J.R.; SONAK, B.; SUEN, H.K. Concept map assessment of classroom learning: reliability, validity, and logistical practicality. Journal of Research in Science Teaching, v.36, n.4, p.475-492, 1999.

MOREIRA, M.A.; BUCHWEITZ, B. Mapas conceituais - instrumentos didáticos, de avaliação e de análise de currículo, São Paulo: Moraes, 1987. 83 p.

MOREIRA, M.A. A teoria da aprendizagem significativa e a sua implementação em sala de aula. Brasília: UnB, 2006. 185 p.

MULFORD D. R. e ROBINSON, 2002, W. R., An inventory for alternate conceptions among first-semester general chemistry students, Journal of Chemical Education, 79 (6), 739-744.

NOVAK, J. D., trad. MOREIRA, M.A., Uma teoria de Educação, Editora Livraria Pioneira, São Paulo, 1981. 252 p.

NOVAK, J.D., GOWIN, D.B. Aprendiendo a aprender. Barcelona: Martínez Roca, 1988. 228p

NOVAK, J.D. Ayudar a los alumnos a aprender cómo aprender- la opinión de un profesor-investigador. Enseñanza de Las Ciencias, v.9, n.3, p.215-228, 1991.

NOVAK, J. D., Cañas, A.J., 2006, The origins of the concept mapping tool and the continuing evolution of the tool. Information Visualization, 5(3) 175-184.

ONTORIA, A. (Org.). Mapas conceptuales - una tecnica para aprender. 5.ed. Madrid: Ediciones Madrid,1995. 207 p.

PERNAA, J. e MAIJA, A. Future chemistry teachers use of knowledge dimensions and high-order cognitive skills in pre-laboratory concept maps. Proceedings of the Fourth International Conference on Concept Mapping p. 137, 2010 Disponível em: http://cmc.ihmc.us/cmc2010papers/cmc2010-137.pdf Acesso em: 30 de outubro de 2010

QUILEZ-PARDO, J. Students'and teachers' misapplication of Le Chatelier Priniceples: Implications for the Teaching of Chemical Equilibrium, Journal of Research is Science Teaching, 32 (9), 939-957,, J., 1995

QUILEZ-PARDO, J. e SanJosé-LOPEZ, 1998, V. Errores conceptuales en el estudio del equilibrio químico: Nuevas aportaciones relacionadas com la incorreta aplicación del principio de Le Chatelier. Ensenãnza de Las Ciencias, v. 12, p. 123-133, 1995. 
QUILEZ-PARDO, J., e SOLAZ-PORTOLES, J., 1995, Students' and teachers' misapplication of Le Chatelier's principle: Implications for the teaching of chemical equilibrium, Journal of Research in Science Teaching, 32, 939-957.

RAVIOLO, A. e AZNAR, M. M., 2003, Uma revisión sobre las concepciones alternativas de los estudiantes em la relación con el equilibrio químico. Clasificación y síntesis de sugerencias didáticas, Educación Química, 13 (3), 159-165.

RAVIOLO, A. e GARRITZ, A., 2008, Analogias no Ensino do Equilíbrio Químico, Química Nova na Escola, n 27, p.13-25, 2008.

ROSS, B.; MUNBY, H. Concept mapping and misconceptions: a study of highschool students' understandings of acids and bases. International Journal Science Education, v.13, n.1, p.11-23, 1991.

RUIZ-MORENO, L, et al. Mapa conceitual: Ensaiando critérios de análise. Ciência \& Educação, v. 13, n. 3, p. 453-463, 2007.

RUIZ-PRIMO, M. A. (2004). Examining concept maps as an assessment tool. In Cañas, A. J., Novak, J. D., y González Fermín (eds). Concept Maps: Theory, Methodology, Technology. Proceedings of the First International Conference on Concept Mapping. Vol. 1. (pp. 555-562) Pamplona: Univ. Pública de Navarra. http://cmc.ihmc.us/papers/cmc2004-036.pdf

RUIZ-PRIMO, M.A.; SHAVELSON, R.J. Problems and issues in the use of concept maps in science assessment. Journal of Research in Science Teaching. v.33, n.6, p 569-600, 1996.

RUIZ_PRIMO, M.A., SCHULTZ, S.E. e SHAVELSON, R. J., Comparison of the Reliability ans Validity of Scores form two Concept-Mapping Techniques, Journal of Researchin im Science Teaching, 38 (2), 260-278, 2001.

SABADINI, E. e BIANCHI, J.C.A, Ensino do conceito de equilíbrio químico: uma breve reflexão. Química Nova na Escola, n² 25, p. 10-13, 2007.

SAKAGUTI, S. T. Mapas Conceituais e Seus Usos: Um Estudo da Literatura. 2004. 84 f. Dissertação (Mestrado em Engenharia da Computação) - Instituto de Computação, Universidade Estadual de Campinas, Campinas. 2004.

SOKAL, R. \& ROHLF, F.Biometry. San Francisco: W. H. Freeman and Company. 1985

SOLANO FLORES, G. Principios de análisis estructural educativo. Metodologías sy técnicas para la educación: México: 2da edición, Trillas: 1989 
SOYIBO, K. Using concept maps to analyze textbook presentations of respiration. The American Biology Teacher, v.57, n.6, p. 344-350, set-1995.

SKOOG, D. A., WEST, D. N. Fundamentos de química analítica. Barcelona : Reverte, 1974., 2005, Pioneira

TSARPALIS, G., KOUSATHANA, M. e NIAZ, M., 1998, Molecular-Equilibrium problems: manipulation of logical structure M-demand, and their effect on student performance, Science Education, p. 437-454.

TURNS, J., ATMAN, C.J., Adams, R. (2000) "Concept Maps for Engineering Education: A Cognitively Motivated Tool Suporting Varied Assesment Functions", In: IEEE Transactions on Education, No. 2, vol. 43.

UEHARA, FABIA M. G. 2008, Refletindo dificuldades de aprendizagem de alunos do ensino médio no estudo do equilíbrio químico. Disponível em: http://www.ppgecnm.ccet.ufrn.br/publicacoes/publicacao_46.pdf. Acesso em: 22/11/2009.

WILSON, A. H., Equilibrium: A teaching/learning activity, Journal of Chemical Education, 75(9), 1176-1177, 1998.

Yin, Y., Vanides, J., Ruiz-Primo, M. A., Ayala, C. C. \& Shavelson, R. J. (2005). Comparison of Two Concept-Mapping Techniques: Implications for Scoring, Interpretation, and Use. J. of Res. in Science Teaching, 42(8), 705-711. 


\title{
ANEXO 1-Instruções para realização dos mapas conceituais
}

\author{
Nome: \\ Atividade: \\ MAPA CONCEITUAL \\ 1.Localize os conceitos \\ 2. Caso não conheça o significado de algum dos conc eitos ab aixo, faça um círculo ao \\ redor do mesmo. \\ 3.Liste os conceitos em uma ordem hierárquica. \\ 4.Distribua os conceitos em duas dimensões. \\ 5.Traçe linhas que indiquem as relações entre os conceitos. \\ 6.Escreva a natureza da relação. \\ 7.Revise e refaça o mapa final. \\ Seguindo as regras acima ou as regras entregues na aula passada, faça um mapa \\ conceitual para o tema EQUIL IBRIO QUIMICO. Para isso utilize a lista de conceitos \\ abaixo.

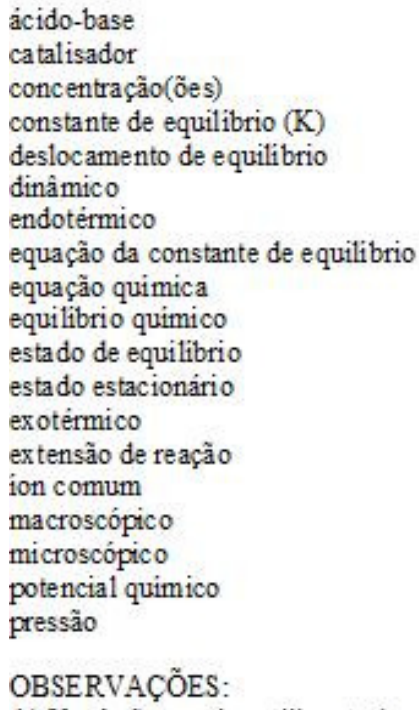

OBSERVAÇÕES: \\ A) Você não precisa utilizar todos os conceitos acima e pode acrescentar outros que não \\ estejam na lista masjulgue pertinentes. \\ B) Você pode combinar dois ou mais destes conceitos. \\ Ex. concentração + reagentes $=$ concentração de reagentes \\ C) Se achar mais fácil, você pode montar vários mapas menores e depois conectá-los.
}

